Portland State University

PDXScholar

2-11-2004

\title{
Contested Visions of Place: People, Power, and Perception on the Columbia's North Shore, 1805-1913
}

Donna Lynn Sinclair

Portland State University

Follow this and additional works at: https://pdxscholar.library.pdx.edu/open_access_etds

Part of the History Commons

Let us know how access to this document benefits you.

Recommended Citation

Sinclair, Donna Lynn, "Contested Visions of Place: People, Power, and Perception on the Columbia's North Shore, 1805-1913" (2004). Dissertations and Theses. Paper 3068.

https://doi.org/10.15760/etd.3066

This Thesis is brought to you for free and open access. It has been accepted for inclusion in Dissertations and Theses by an authorized administrator of PDXScholar. Please contact us if we can make this document more accessible: pdxscholar@pdx.edu. 


\section{THESIS APPROVAL}

The abstract and thesis of Donna L. Sinclair for the Master of Arts in History were presented February 11, 2004, and accepted by the thesis committee and the department.

COMMITTEE APPROVALS:

William Rang, Chain

David Hoғpwitz

David Johnson

Barbara Brower

Representative of the Office of Graduate Studies

DEPARTMENT APPROVAL:

Lindá W̌alỉon, Ehair

Department of History 


\section{ABSTRACT}

An abstract of the thesis of Donna L. Sinclair for the Master of Arts in History presented February 11, 2004.

Title: Contested Visions of Place: People, Power, and Perception on the Columbia's North Shore, 1805-1913

This is a narrative of place, of intersections between people, power, and perception of landscape. The environs of the Columbia River Gorge create a very distinct sense of place. Where once a series of three rapids - the Cascades of the Columbia - blocked industrial upriver transport, now Bonneville Dam and Locks allows smooth passage. To the north the vast 1.3 million acre Gifford Pinchot National Forest dominates the landscape. On the Columbia's banks lies the town of Stevenson, Washington, with Carson a few miles away, in a transitory ecological zone between east and west, at the forest's edge. There, community development has been manifestly influenced by human relationships to the landscape.

Contested visions of place during the nineteenth century resulted in violent conflict and framed debates over place. Examining struggles over who would control access, first to the Cascades of the Columbia, and then to the timber of the Wind River Valley, provides a venue for examining power - of nature, ideas, and changing human cultures as overlapping groups imposed their views of the good 
life onto the landscape. As each successive group gained power, the relationships of humans to the land, and to one another, changed.

By examining historic connections between river and forest, and between human communities to each, this study identifies multiple meanings of the same environment for different groups. I use a bioregional approach, exploring relationships between land, people and resources on the Columbia's north bank between 1805 and 1913. Power relations at the Cascades and in the forest were determined through conflict, negotiation, and the federal government, with the human relationship to nature influencing outcomes. Conflict often resulted from struggles over access to place, while human groups negotiated their place within the landscape. Nature privileged one group over another through disease, fire, and human perception, while the United States government co-opted place through public land laws, Indian removal, and by measuring and bounding the landscape. Who gained access to the river and forest of the Columbia's north shore, and how they did it, is the focus of this story. 
CONTESTED VISIONS OF PLACE: PEOPLE, POWER, AND PERCEPTION ON THE COLUMBIA'S NORTH SHORE, 1805-1913

by

DONNA L. SINCLAIR

A thesis submitted in partial fulfillment of the

requirements for the degree of

\author{
MASTER OF ARTS \\ in \\ HISTORY
}

Portland State University

2004 


\section{ACKNOWLEDGMENTS}

In order to acknowledge those who have played a role in shaping this work I must start at the beginning. Special thanks go to my mother, Jade Leslie Ward, for consistently encouraging my education. Never once did she doubt my path, even when it meant I did not know where I would end up professionally, or that I needed help in providing school clothes for my own children. Thank you for always being there, Mom.

Next, thanks go to my children, Jacob, Danielle and Christopher. It is they who have been most affected by my graduate studies and other public history work. Night after night throughout their childhoods they have listened to a clattering keyboard at the kitchen table, and contended patiently with my intermittent periods of intensive writing. I don't think any of them can remember a time when their mother was not regularly lost in thought, studying at soccer or baseball practice, or telling them stories about the Columbia Basin. I can only hope they will someday appreciate those stories.

I want to thank William Lang above all. Without his mentoring, encouragement, and ongoing support I would not have been able to attend graduate school, work at the Center for Columbia River History, or become a historian. From the day I walked into his undergraduate Pacific Northwest History class in the fall of 1993, he has played a major role in shaping my view of history. Thank 
you Bill for the many opportunities, but mostly for helping me to find my own sense of place.

There are many others who have been significant in my completing this work, and who have supported me for the past several years. I thank the following:

- Katrine Barber, for intellectual discussions of rivers, forests, and history, and mainly for the sustaining friendship in uncountable areas

- Richard McClure, for telling me about rough-and-ready rangers, providing research materials, and especially for sharing my excitement about forest history

- Richard Hansis, for drawing me to the Gifford Pinchot National Forest, beargrass, and environmental thought

- Cain Allen, for many rich discussions, and for our joint explorations of the Columbia Basin

- Barbara Jo VanKregten-Ivey, for always being there

- Clayton Mosher, for friendship, support, and continual faith in my abilities

- My many friends and family members who have supported me academically and personally. I am fortunate to have more than I can name. 


\section{TABLE OF CONTENTS}

ACKNOWLEDGMENTS.

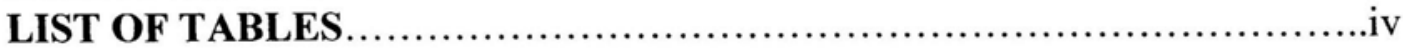

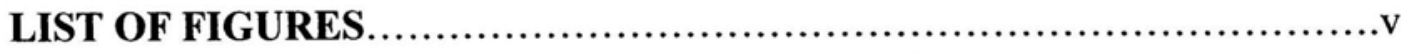

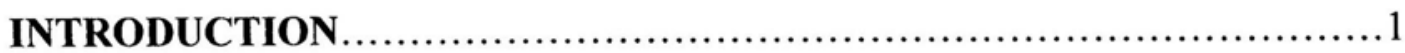

CHAPTER ONE: SWIFT WATERS, GRAND FORESTS, AND A SENSE OF PLACE IN SOUTHERN SKAMANIA COUNTY

Cataclysms on the Columbia's North Shore..............................13

Oral Tradition and a Sense of Place................................... 18

Rivers, Forests, and the People of the Rapids.............................23

Reshaping the Ecological and Social Landscape...........................38

CHAPTER TWO: TRANFORMING THE COLUMBIA'S NORTH SHORE

Jeffersonian Democracy in the Pacific Northwest........................50

Takeover at the Cascades..............................................62

"We have got to work": logging, lumbering and building community......82

Land Fraud, Agrarian Ethics, and Lumbering in the Wind River Valley...90

CHAPTER THREE: PROGRESSIVE CONSERVATION, TREE FARMING AND THE "IDEA" OF FORESTRY

The Roots of Forest Conservation....................................101

Legislating the Forests.............................................. 112

Examinations and Boundaries........................................120

Opposition to Forest Reserves in Washington State......................129

CHAPTER FOUR: TREE FARMING IN THE AGRICULTURAL EMPIRE

Protest, Fire, and Public Improvement................................141

A Most Efficient Organization........................................156

Homesteading in the Forest............................................ 169

\section{CHAPTER FIVE: PINCHOT'S MIDNIGHT OF INFAMY}

IN SKAMANIA COUNTY

Scientific Forestry and Community..................................175

The Battle Thickens..................................................182

The Forest Service Takes Hold.....................................200

The Community and the Forest.........................................202

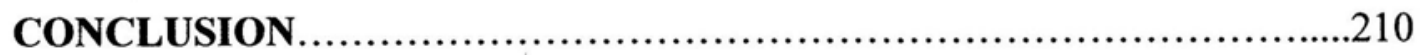

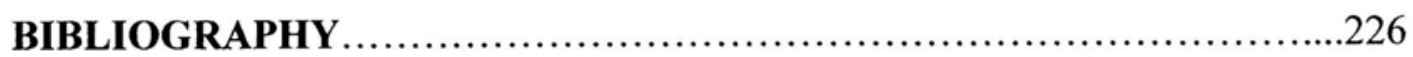




\section{LIST OF TABLES}

Table 1: Arable Land, Mt. Rainier Forest Reserve, 1900_......................126

Table 2: Timber Estimates, Mt. Rainier Forest Reserve, 1900..................127

Table 3: Assessed value, Township 4, 1902 .................................135

Table 4: Lumbering Companies or Sawmills, 1850-1921 ......................144 


\section{LIST OF FIGURES}

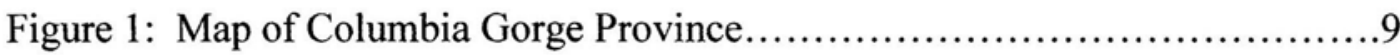

Figure 2: Map of Skamania County and the Gifford Pinchot National Forest......10

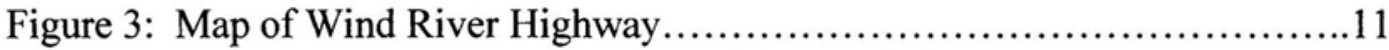

Figure 4: Map of Gifford Pinchot National Forest and Vicinity.................12

Figure 5: Map of North Bank Columbia River Land Claims.....................86

Figure 6: Photo of An Abandoned Homestead................................133

Figure 7: 1908 Land Claim Map............................................

Figure 8: Photo of Log Boom, Columbia River..............................152

Figure 9: Photo of Splash Dam on Wind River...............................153

Figure 10: Photo of Log Drive on Wind River.............................154

Figure 11: Photo of Elias J. Wigal....................................... 166

Figure 12: Photos of Wind River Nursery site, ca. 1909-1911 .................178

Figure 13: Photo of Carson, Washington, ca. 1910 ..........................186

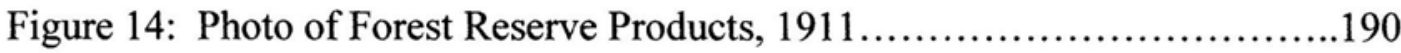

Figure 15: Wind River Lumber Company Railroad, ca. 1913-1925 .............206

Figure 16: Forest Service/community competition..............................209 


\section{INTRODUCTION: A SENSE OF PLACE IN THE COLUMBIA RIVER GORGE}

The Columbia River wells up from a lake in British Columbia, gathering speed and mass as it snakes its way to the ocean over 1,200 miles away. The river drains a 259,000 square mile basin, in which every flowing body of water - river, stream, and puddle - eventually joins the Columbia as it wends first north, then west and east, and eventually takes a southwesterly course to the ocean. As the liquid of the basin is carried seaward, it first passes through a massive gorge carved long ago by the Columbia's powerful presence. On the north shore of the rock strewn gorge a vast forest dotted with big timber extends across the Cascade Range, a bounded 1.3 million acres of public land called the Gifford Pinchot National Forest. To the north, the forest dominates the landscape and the Columbia's tributaries - the Wind, the Little White Salmon and the White Salmon rivers - flow through the mountains emptying into the big river. To the west, where the Rocky Cascade Rapids once dominated the view on the Columbia, Bonneville Dam now stands, the first major human edifice built to reshape this part of the river. ${ }^{1}$

Skamania County, a land of rivers, red-tinted Indian paintbrush, moss and boulders, spiked beargrass and fir, borders the Columbia River on the south, stretching north through the Cascade Range in Washington State. Small towns

\footnotetext{
${ }^{1}$ Bonneville Dam, built in 1938 by the U.S. Army Corps of Engineers, is one of 14 major dams on the Columbia River. The technological control of the Columbia through dams has prompted historian Richard White to coin the nickname "Organic Machine" for the river once called N'chi Wana, or "Big River." For more about changes on the Columbia, see Richard White, Organic Machine: The Remaking of the Columbia River (Hill \& Wang, 1995).
} 
established over a century ago rest on the periphery of river and forest, Stevenson, upriver on the Columbia, and Carson a little more than three miles to the northeast at the southern edge of the forest's Wind River Valley. The Wind River watershed is a transitory zone. The Cascade Crest stretching through the valley divides the arid inland empire on the east from the temperate, forested west side of the mountains. Originating approximately twenty miles north of the town of Carson, the thirty-one-mile long Wind River winds through a basin with elevations ranging from 3,900 feet to 80 feet. During the early contact period the valley was a diverse ecosystem of old-growth forest. Massive 200 to 500 year-old, moss-lined fir shadowed areas of multiple-aged species of younger trees, snags, downed wood, and vegetation generated by sporadic fire within the basin. ${ }^{2}$

Geographers have long examined place, moving historically from analyses based on geographic determinism and cultural causality to more complex studies about webs of meaning in the human environment relationship. As geographer Robert David Sack explains, an understanding of place comes through the interrelatedness of nature, meaning and social relations. Place and space are forces that "braid together nature and culture (which includes social relations and meaning)," and help to constitute identity, both in terms of the individual and the community. ${ }^{3}$ Geographer Nicholas Entrikin recommends connecting objective fact with subjective understanding of place through a narrative-like synthesis of

\footnotetext{
${ }^{2}$ U.S.D.A. Department of Agriculture, Forest Service, Wind RiverBasin Watershed Analysis: Gifford Pinchot National Forest (Gifford Pinchot National Forest: Wind River Ranger District South Skills Center, April 1996), III-3-14.
} 
temporal event and geographic space, one that allows us to see things together.

Entrikin urges us to approach place contextually, examining existential qualities of experience and the objective material world - the "betweenness" of place. ${ }^{4}$

Geographer Yi Fu Tuan poses questions about space, place and "the good life" through relationships between individual experience and the context of place, past and present. For Yi-Fu Tuan, "Space plus culture equals place." Denis Cosgrove sees place, "simultaneously as [a] thing and as [a] sign of meaning beyond itself."

Historian William Lang suggests that environmental historians can make use of the geographer's approach by asking three generally posed questions: "How have we perceived place? What has place symbolized in our culture? And what have we accepted and discarded about earlier meanings of place?" ${ }^{6}$ Together, river and forest create a special sense of place on the Columbia's north shore, a setting that has been occupied by human communities for thousands of years.

Environmental historian Dan Flores explains the close linkage between ecological locale and human culture through a concept of "changeability" within human cultures that occupy a particular space:

\footnotetext{
${ }^{3}$ Robert David Sack, Homo Geographicus: A Framework for Action, Awareness, and Moral Concern (Baltimore: John Hopkins University Press, 1997), 1.

${ }^{4}$ Nicholas Entrikin, The Betweenness of Place: Towards a Geography of Modernity (Baltimore: Johns Hopkins University Press, 1991), 6, 23-26.

${ }^{5}$ Flores, "Place," 37; Cosgrove in Lang, "Sense of Place," 89.

${ }^{6}$ William L. Lang, "The Sense of Place and Environmental History" in Northwest Lands, Northwest People: Readings in Environmental History. eds. Dale D. Goble and Paul W. Hirt (Seattle: University of Washington Press, 1999), 85; Yi-Fu Tuan, The Good Life (Madison: University of Wisconsin Press, 1986), 3-11; Entrikin, Betweenness of Place, 8, 18-19.
} 
a given bioregion and its resources offer a range of possibilities from which a given human culture makes economic and lifeway choices based upon the culture's technological ability and its ideological vision of how the landscape ought to be used and shaped to meet its definition of a good life.

Within each locale, a narrative line of "different, but sequential cultures" create their own succession of places," interacting "with a 'nature' more or less altered by previous inhabitants." According to Lang, what Flores "seem[s] to be saying is that where something happens makes as much difference as what happens." 8 The ecological zone between forest and river on the Columbia's north shore is one place where human changeability and sequential cultures have formed a historic landscape altered and perceived differentially by the groups who have lived there and made use of its resources. This zone, between river and forest, valley and bottomland, has distinctly influenced community building and relationships through intersections between local and national political, economic and social forces.

Not only does where something happens make as much difference as what happens, but perceptions of place and events also influence human identity. Understanding experience, or sense of place, for individuals or communities cannot be fully captured through objective theoretical social science. Historical understanding of place occurs by capturing the material and the ideal, natural elements and human construction. Human agency transforms the morphology of

\footnotetext{
${ }^{7}$ Dan Flores, "Place: An Argument for Bioregional History" in Northwest Lands, Northwest People: Readings in Environmental History, eds. Dale D. Goble and Paul W. Hirt (Seattle: University of Washington Press, 1999), 35, 37-38.

${ }^{8}$ Ibid, 41; Lang, "Sense of Place," 81.
} 
the natural landscape, and in turn, nature has the potential to alter the social landscape. The physical and social changes that occur through conscious human agency and/or through natural processes that result from human relationships to place form the context of community identity. These processes are further shaped by the external structures of the nation state. ${ }^{9}$

Dan Flores suggests a theoretical approach to the history of place that begins by looking at deep time in a single space, and doing away with false nature/culture dichotomies. Instead, Flores claims that studying bioregional divisions such as watersheds and intermontane basins can more effectively elicit processes of historical change than political or economic divisions can. Bioregional history should begin with geology and landform and then look at climate and culture. Like Entrikin, he proposes submerging theoretical structure to historical narrative, and allowing the story of place to reveal meanings. What Flores, Entrikin and others seem to propose is a synthesis between the French longue duree and milieu, deeptime and sense of place. ${ }^{10}$

Understanding history on the Columbia's north bank is best approached by examining changing indigenous and Euro-American cultural relations to place: through the gorge's ecological, social and historical beginnings: the birth of the gorge; its meanings to different groups; intersections between forest and river use; and relationships between groups of people and the landscape. This is a history of community and conflict on the Columbia's north shore between 1805 and 1913

\footnotetext{
${ }^{9}$ Entrikin, Betweenness of Place, 6, 24-26.
} 
when Euro-American settlement took place and federal control of the landscape became cemented. It is also a history of changing cultures, landscapes, and perceptions of place. The focus is on relationships - of humans to river, forest, and one another - and how those relationships influenced community development and altered the landscape. It is not a scientific site review, but rather a study in community changeability and development as overlapping groups imposed their very distinct ideas about resource use and meaning onto the Columbia's north shore and moved into the Wind River Valley. Moreover, it is an examination of connections between places.

In Chapter One I describe the creation of the Columbia River Gorge, Native American communities on the Columbia's north shore, and the early contact period. My focus is on use of forest resources and their very important role in facilitating access to Columbia River resources. Indians used the resources of the forest almost as intensely as those of the river by hunting, fishing, and harvesting the huckleberry crop in the high country, and fashioning fishing tools from wood products and stone. Indigenous resource use took place in a world interpreted by native peoples as animated and alive, a world of connections between humans, the land, and other beings. In this world, humans had influence without control, save through cultural behavior, access to resources without certainty, and respect for the power of a place imbued with life spirit. Euro-Americans approached the land differently, their perceptions shaped by ethics of use, productivity, and domination

\footnotetext{
${ }^{10}$ Flores, “Argument," 40-42; Entrikin, Betweenness of Place, 6.
} 
of nature. As Native Americans encountered Euro-Americans and disease ravaged local Indian groups, a biotic and cultural transformation began in the Columbia River Gorge. For centuries, indigenous groups controlled passage and trade between the east and west sides of the Cascade Mountains through a portage trail at the Cascades. By 1854, as Skamania County formed, Euro-Americans began to settle the Columbia's north shore in full force.

In Chapter Two I look at how that transformation proceeded over the next half-century as Euro-Americans changed their perception of forest and river from barriers to venues for wealth. The rocky Cascade Rapids, at first an obstacle for American migrants, became opportunity, while the once gloomy forests provided additional subsistence opportunities for early settlers. Americans settled the lowlands early, and as communities grew, they filed claims on forestlands as well. By the 1870s and 1880s, many moved into the Wind River Valley. My focus is on the changing relationship of human communities to forest and river, the impact of ideas of Jeffersonian democracy, and the shift from an indigenous spiritual and place-based value system to an instrumentalist Euro-American use-based value system. Whereas Indians viewed the river and the forest as part of a world in which spirit infused even the trees and the rocks, American migrants perceived the landscape in terms of utility.

In Chapter Three, I focus on the way in which national conservation policies impacted the Columbia's north shore in the 1890s, as eighty-percent of Skamania County came under federal management. The cultural and physical landscape of 
the county transformed as the U.S. extended its reach across the West, and concepts of scientific utility and economic prosperity took hold. Despite an outcry of protest from western stockmen, lumber and mining interests, an attempt to impeach the president, and a Senate amendment to abolish forest reserves, the national forest system thrived and strengthened.

Chapters Four and Five examine the ways in which the "idea" of what a place is and should be affected behavior at the turn of the century in Skamania County. Conflict over access to forest resources between those in Stevenson and Carson, boosterism, and ideas of an agricultural empire distinctly influenced community development in both places. At the same time, the newly-created U.S.D.A. Forest Service developed a stronghold on the county's forest resources and a struggle ensued over who would benefit most from the timber of the Wind River Valley. The battle over timber and land in the Wind River Valley is a study in the power of ideas and the power of place, and that is the focus of my final chapter, and ultimately of this history. 


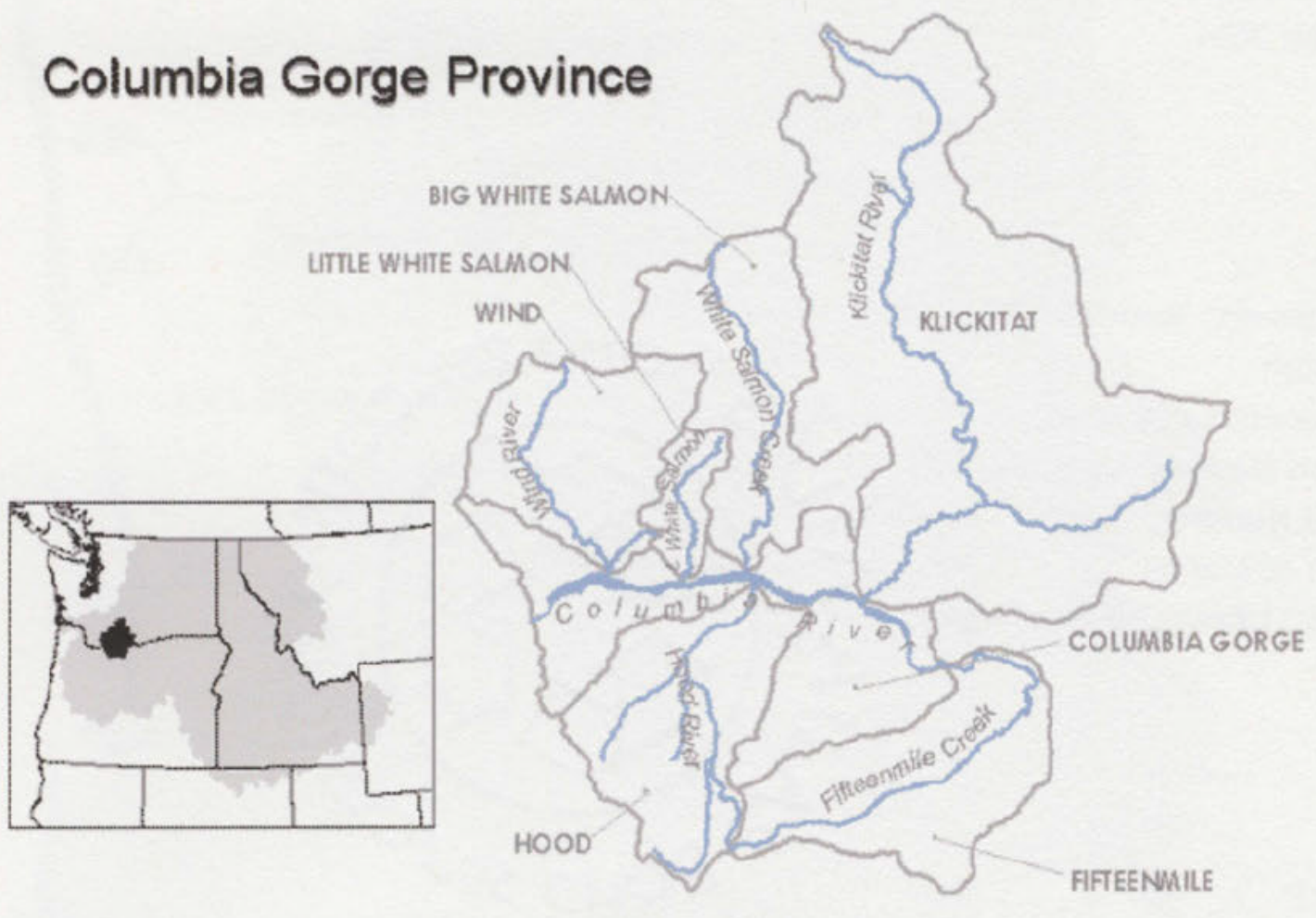

Figure 1: Columbia Gorge Province

Columbia Basin Fish \& Wildlife Authority Map,

http://www.cbfwa.org/files/province/gorge/maps/columbiagorge.gif 


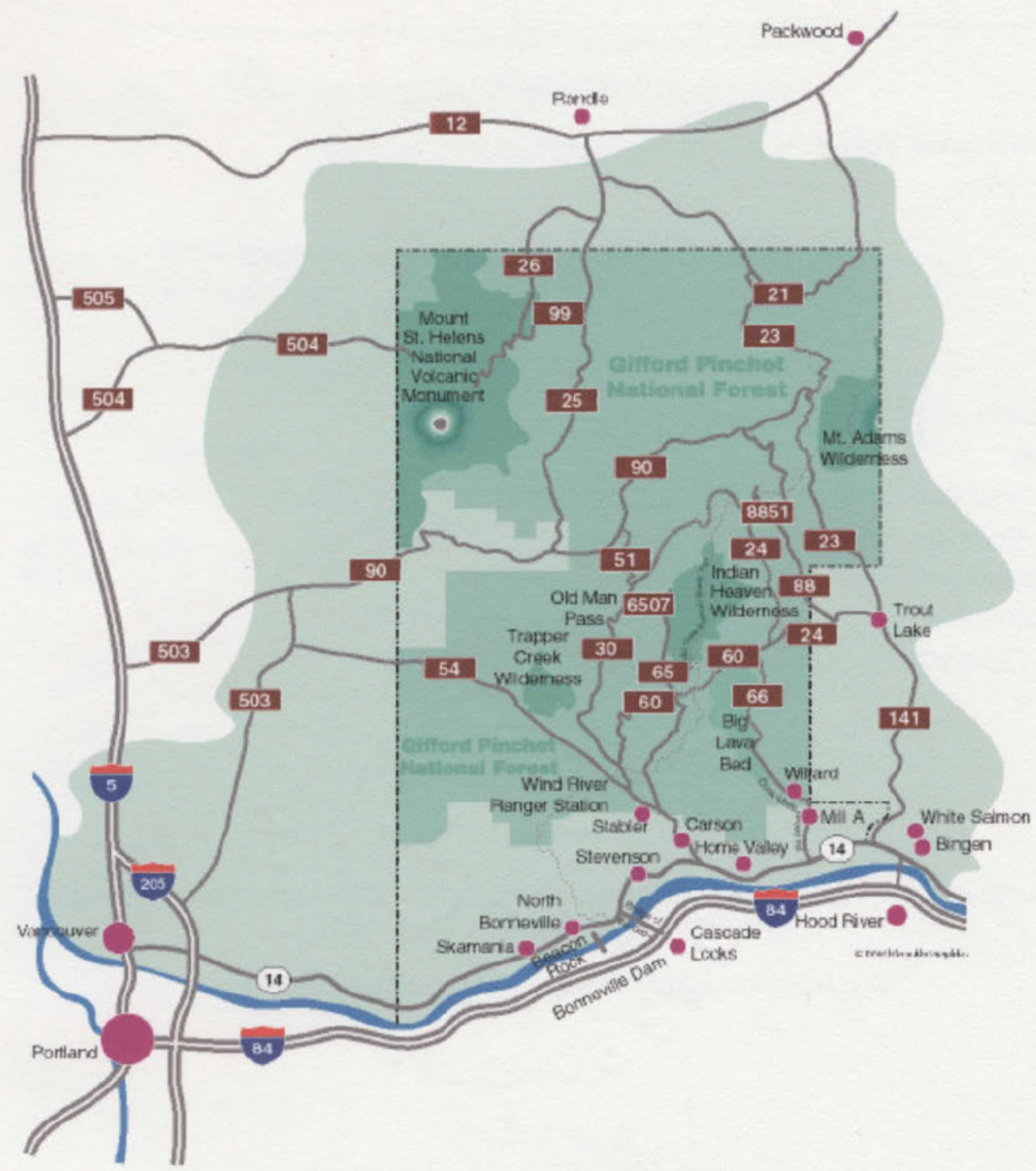

Figure 2: Skamania County and the Gifford Pinchot National Forest

U.S.D.A. Forest Service Map

http://www.fs.fed.us/r6/columbia/maps/map.htm 


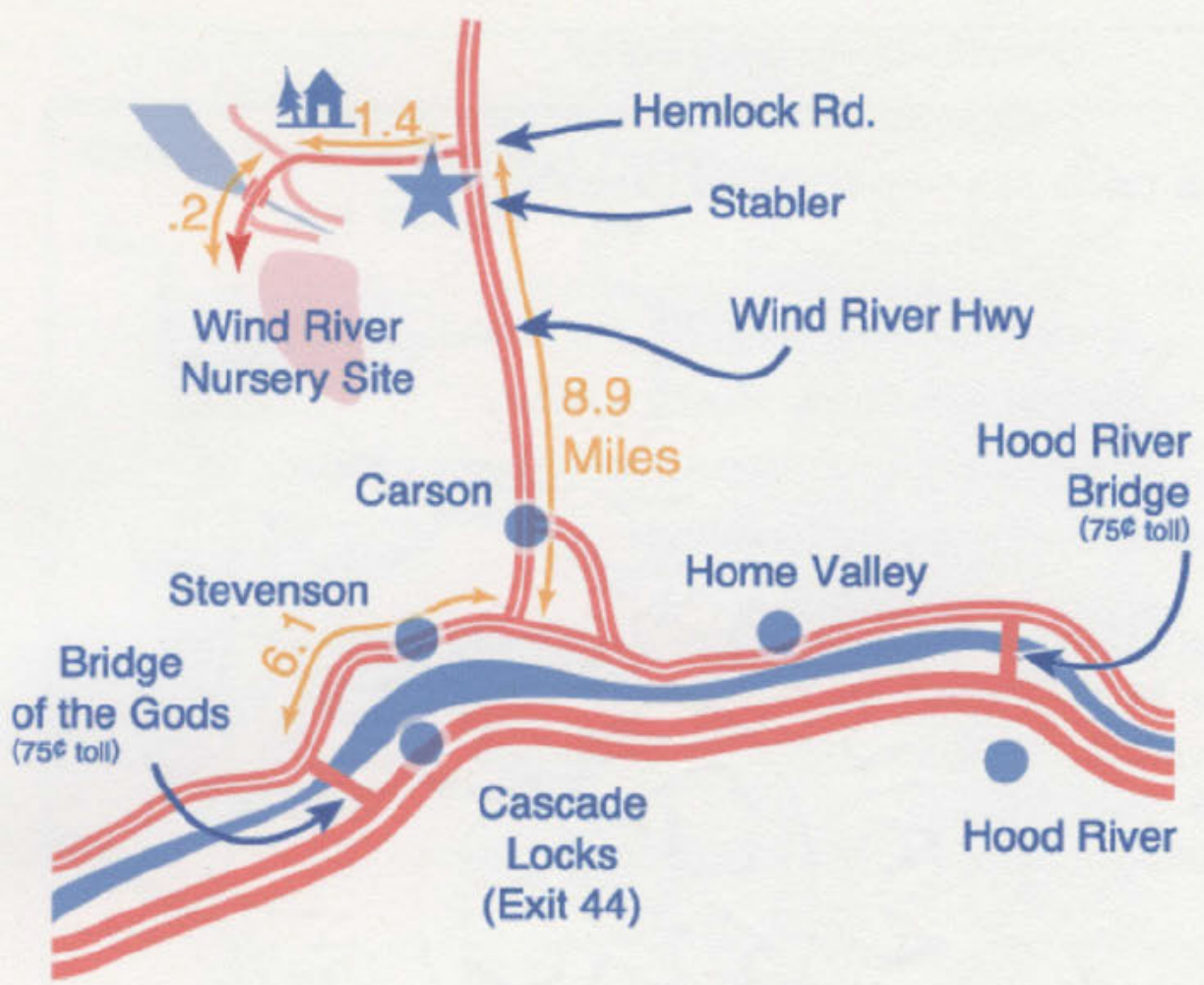

Figure 3: Wind River Highway

Washington State SAR Conference Maps from The Skamania County Sheriff's Office and Wind River Search and Rescue Conference, 2002

http://www.riverside-graphics.net/sar02/Map.html\#MarthaCreek 


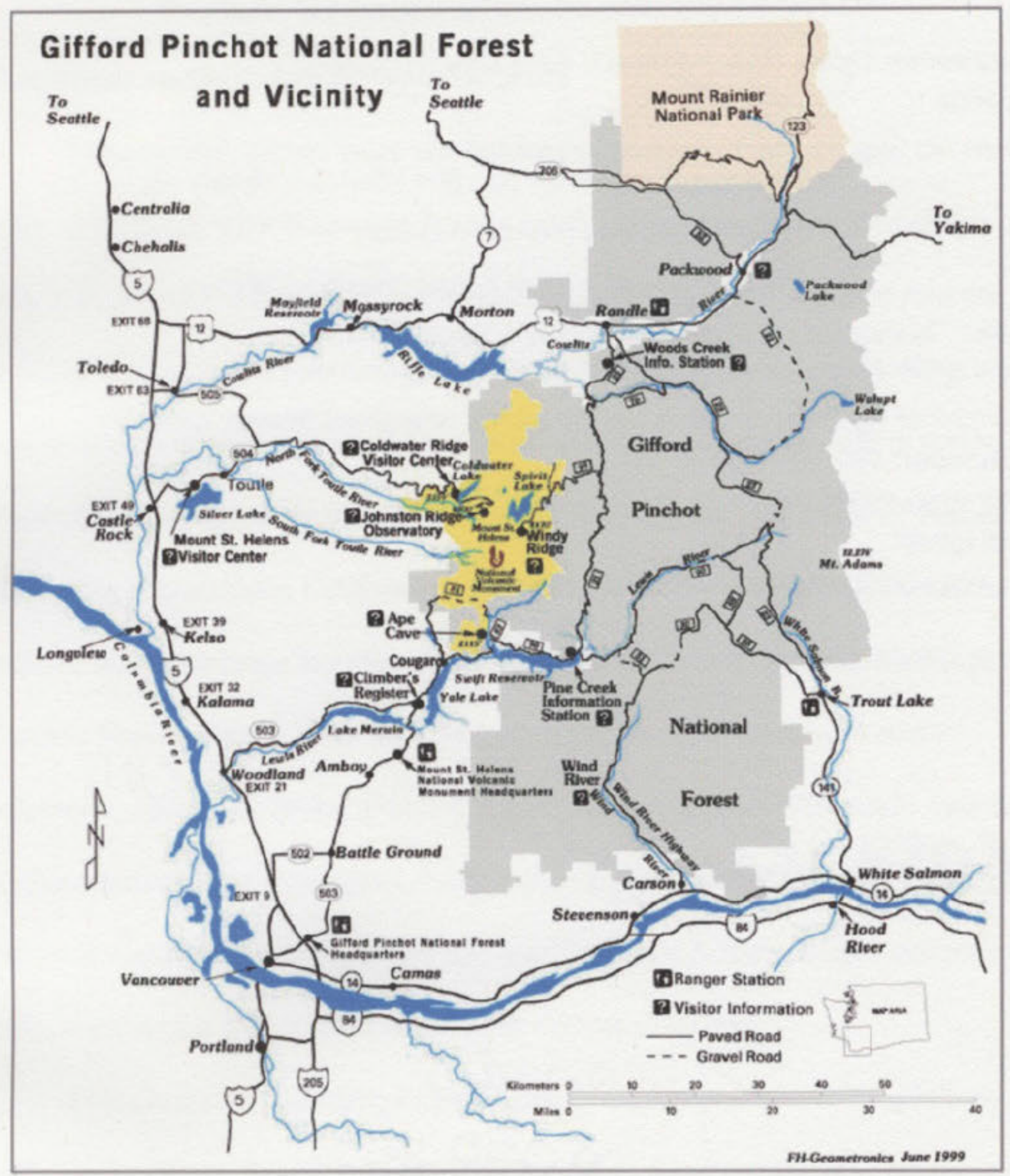

Figure 4: Gifford Pinchot National Forest and Vicinity

U.S.D.A. Forest Service Map

http://www.fs.fed.us/gpnf/global/images-other/gpnf vicinity.jpg 


\section{CHAPTER ONE: SWIFT WATERS, GRAND FORESTS, AND A SENSE OF PLACE IN SOUTHERN SKAMANIA COUNTY}

\section{Cataclysms on the Columbia's North Shore}

Forty to fifty million years ago bursting mountains of magma split the crust of the earth along what is now the Pacific coast, intermittently carrying mantles of molten lava over the landscape of the interior northwest. As mountains rose and collided, the Columbia tore through the Cascade Range, curving and twisting to find its way to the sea. Nearly 700 miles of mountains link from north to south in a chain of fire through the states of Oregon and Washington, with a line of volcanoes continuing into northern California. Known as the mountains by the Cascades Indians, the entire range later became The Cascades. The Southwest Washington Cascade Mountains comprise the youngest of the Pacific Northwest's strato volcanoes. Mount St. Helens, known to native groups as Loo Wit, stands near the northwestern edge of Skamania County in the Gifford Pinchot National Forest. To the north stands Mount Rainier and northeast is Mount Adams. These mountains, built over the past half million years, form the Cascade Crest. ${ }^{1}$

This divergent landscape formed through catastrophic events long before human occupation. Somewhere between 15 and 12.8 thousand years ago, the last of perhaps hundreds of major floods, known as the Bretz or Missoula Floods, molded the landscape as we know it today. Prior to these floods the hills and valleys appear much as we see them today, with glacial peaks and uplands in the

\footnotetext{
${ }^{1}$ Daniel Mathews, Cascade-Olympic Natural History: A Trailside Reference, 2d ed. (Portland: Raven Editions, 1999), 9-10.
} 
Cascades and Rockies. Lower temperatures, more rainfall, larger rivers and heavier snowfall characterized the landscape. A continental ice sheet covered much of Canada, and, write Allen et. al. in Cataclysms on the Columbia:

The Columbia Plateau was a great, undulating, gently-sloping, grassy, sparsely-wooded plain, bounded on the west by the Great Bend of the glacially-swollen Columbia River. Choked by glacial outwash, the river spread out in a multitude of channels...2

This gently rolling landscape changed catastrophically at the end of the last Ice Age as huge glacial floods carved a new landscape across the Pacific Northwest.

During the Pleistocene, the Cordilleran Ice Sheet crept into the middle of Idaho's panhandle, damming the mouth of the Clark Fork River, and backing water up over much of western Montana. The sheet created a massive body of water known as Glacial Lake Missoula, a great inland sea that stretched eastward for some 200 miles at some points, and containing more water than Lake Erie and Lake Ontario combined. Periodically, as many as forty or more times, water spilled over the ice sheet, which burst massively in catastrophic floods of ice, dirt, and rock filled water that roared across northern Idaho and eastern and central Washington, through the Columbia River Gorge, into Oregon's Willamette Valley, and finally to the Pacific Ocean at the mouth of the Columbia. When the high ice dams broke, the amount of speed and flow of water burst out at ten times the combined flow of all the rivers of the world. The mass of water stripped cut deep canyons into the bedrock and stripped away hundreds of feet of soil at speeds approaching sixty-five miles per

\footnotetext{
${ }^{2}$ John Eliot Allen, Marjorie Burns, and Sam C. Sargent, Cataclysms on the Columbia: A Layman's Guide to the Features Produced by the Catastrophic Bretz Floods in the Pacific Northwest (Portland, OR: Timber Press, 1986), 81.
} 
hour. These events occurred repeatedly over a period of approximately 2,500 years, shaping the landscape as it exists in the twenty-first century and leaving miles of carved out earth, mountains of gravel, and 200-ton boulders from the Rockies to the Willamette Valley. ${ }^{3}$

When the rending of a new landscape by fire, ice, and water stopped nearly 13,000 years ago, a steep vibrant gorge cut by the Columbia remained. ${ }^{4}$ The action of the Columbia, a river that moves the second largest volume of water in north America, carved through the volcanic material of the Cascade Mountains, removing as much as 800 meters of rock and basalt in some places. Then massive trees grew, covered with moss, surrounded by fern, dark, damp and decaying, creating habitat for innumerable organisms, plant, animal and human. The Columbia weaves through an eighty-five-mile scarred canyon, 4,000 feet at its crest, with ripped

\footnotetext{
${ }^{3}$ According to Allen, et. al., geologists continue to argue over the number of floods that occurred during this period. Some have suggested as few as two, others as many as seventy. Allen, et. al. propose a series of floods occurring every 55 to 60 years, based on the amount of time it would take to fill the lake behind the ice dam under ice age conditions. Waitt has identified more than $\mathbf{4 0}$ successive flood-laid, sand-to-silt layers resulting from the Missoula floods in southern Washington, and he suggests bursts of flooding "scores" of times, perhaps as often as every three to seven decades during the 2,000 to 2,500 year period of last glacial damming. U.S. National Park Service Website, Ice Age Floods, 2002 on U.S.G.S. Website, http://vulcan.wr.usgs.gov/Glossary/Glaciers/IceSheets/description_lake_missoula.html, [Accessed January 1, 2004]; Richard B. Waitt, Jr., "Case for periodic, colossal jokulhlaups from Pleistocene glacial Lake Missoula," Geological Society of America Bulletin 96 (October 1985), http://vulcan.wr.usgs.gov/Glossary/Glaciers/IceSheets/Waitt85GSA/abstract.html, [Accessed January 1, 2004]; 107-108.

${ }^{4}$ William Dietrich, Northwest Passage: The Great Columbia River (New York: Simon \& Schuster, 1995), 123-130; Rick Minor, Archaeological Testing at 45SA16, Skamania County, Washington. Report to Portland District U.S. Army Corps of Engineers (Heritage Resource Associates, Report No. 33. December 21, 1984), 2.
} 
columns of basalt appearing like pieces of a jigsaw puzzle on either side of the waterway. $^{5}$

More recent landscape change shaped the Columbia Gorge. Scientists have determined that during the past thousand years a series of four landslides took place. The Bonneville Slide, the last and most recent, has been recently dated as occurring sometime between 1550 and 1700 . The massive slide dropped portions of Table Mountain into the Columbia, and produced a temporary dam and vast lake covering more than five-and-a-half miles. The naked face of Table Mountain, a drowned fir forest, and a rocky land bridge remained as visible evidence of the catastrophe. The landslides butted up against the steep southern bank, forming an obstruction possibly three times the height of the present dam. No one knows how long the river was blocked, but as the Columbia wore away the land bridge, the Cascades of the Columbia, created by erosion of debris, remained. ${ }^{6}$

The "Cascades," a series of three rapids known as Upper, Middle, and Lower, where the Columbia constricted and churned and rocks jutted upward in the middle of the river, made passage by boat impossible. For at least 200 years these rapids, now covered by the Bonneville Reservoir, influenced the location and activities of human communities along the northern shore of the Columbia. According to archaeologist Alan Skinner, three major factors affected human settlement near the Cascades: the uplifting of the Cascade Mountain Range; the

\footnotetext{
${ }^{5}$ Michael Spranger, The Columbia Gorge (Pullman: Washington State University Press, 1993), 20.

${ }^{6}$ Allen, et. al., Cataclysms, 165; Richard L. Hill, “A New Look at an Old Landslide," Oregonian 29 September 1999 on U.S.G.S. Website, http://landslides.gov/html files/bonneville/ [Accessed January 1, 2004].
} 
erosional power of the Columbia River; and the long-term impact of the Cascade Landslide. One other factor contributed strongly to human settlement of the area known as the Cascades - the availability of abundant forest resources. The towns of Stevenson and Carson lie nestled between mountain and river just west of the Cascade Range in Washington State. These neighboring communities are in the heart of a region ecologists label an "ecotone," a transitional zone where biotic provinces meet. ${ }^{7}$ For millenia, a catastrophic sequence of fire, ice, and floods shaped this distinctive landscape. Cataclysm created a diverse biome in which forest and river intersected closely, at once isolating human communities from the broader region, and at the same time creating a desirable environment for settlement.

The Columbia River cuts through the Cascade Mountains, the regional dividing line between east and west. At the edge of the river where the community of Stevenson stands, with Carson a little over three miles to the northwest, xeric, or dryland, eastern tree species meet typical western humid species. ${ }^{8}$ The distinctive multi-ecotonal region of the gorge, where east meets west and north meets south, has produced a special sense of place within human communities as well. In the Columbia River Gorge one cannot escape what psychologist James Gibson deems

\footnotetext{
${ }^{7}$ Carole L. Crumley, "The Ecology of Conquest: Contrasting Agropastoral and Agricultural Societies' Adaptation to Climatic Change" in Historical Ecology: Cultural Knowledge and Changing Landscapes, ed. Carole L. Crumley (Santa Fe, NM: School of American Research Press, 1994), 192; Rick Minor, et. al., Overview of Investigations at 45SA11. Archaeology of the Columbia River Gorge (Eugene: Heritage Research Associates, 1989), 21.

${ }^{8}$ Minor, Overview of Investigations, 22.
} 
the "haptic," the "sense or the power of the physical touch of place." Thus, a human sense of place within the gorge includes relationships between biological and geological communities.

\section{Oral Tradition and a Sense of Place}

The geologic events that created the Columbia River Gorge and the Cascade Rapids profoundly affected human communities on the river. The region's river and mountain geology added to the haptic sense of place passed from one generation and culture, to another. Before scientists described the gorge's geology in the twentieth century, native peoples "remembered" these catastrophes, later passing them on to Euro-American immigrants. Such memories demonstrate relationships between human communities, the regional environment, and perceptions of the landscape. Even today, Indian people tell legendary stories of coyote, battles between the mountains Klickitat (Adams) and Wy'East (Hood) over the beautiful young Loowit (St. Helens), and relations between native peoples. These tales were originally recorded in print on the Yakama Indian Reservation more than seventy years after an initial sweep of pestilence devastated native people along the Columbia. ${ }^{10}$

\footnotetext{
${ }^{9}$ James Gibson quoted in William Lang, "The Sense of Place and Environmental History" in Northwest Lands, Northwest People: Readings in Environmental History, eds. Dale D. Goble and Paul W. Hirt (Seattle: University of Washington Press, 1999), 88.

${ }^{10}$ For more about the collection of Indian tales on the mid-Columbia, see Donald M. Hines, Where the River Roared: The Wishom Tales (Issaquah, WA: Great Eagle Publishing, 1998).

Anthropologists Edward Sapir, Leslie Spier, and Ella Clark also collected oral traditions from the Wishram, the Upper Chinookan people who lived along the banks of the Columbia from White
} 
Variations of Columbia River legends, myths and origin stories passed from one generation and one group to another as the presence of individuals and communities overlapped. As each new group entered the Columbia Gorge, they incorporated portions of previous lifeways and perceptions into existing cultures. Legends of the Klickitats, native origin tales recorded in the 1930s by Clarence Orvel Bunnell, reveal an intersection between native belief systems and EuroAmerican adoption of cultural memory. Bunnell grew up in the Columbia Gorge northeast of Stevenson, and the tales he heard as a young boy from mid-Columbia Indians made a lasting impression. By the end of the nineteenth century, the people who hunted, fished, and harvested forest resources on the north shore of the Columbia were mainly Klickitat, Wishram, and Yakama, with a few remaining Chinookan Cascades. Bunnell's Legends reflect the relationship between the landscape of the Columbia Gorge and sequential groups of people. The Legends resonate with the sense of an interrelated river and forest, while integrating elements of both native and Euro-American perspectives. Bunnell recounts the Indian tales traditionally passed from generation to generation through his own cultural lenses. As in the Christian origin story, in Bunnell's Legends human creation follows the rise of animals, trees, and plants "because it is necessary that Man have all these in order that he may find food and clothing."

\footnotetext{
Salmon to Celilo Falls, as did Indian advocate Lucullus V. McWhorter. For additional variations in native tales, See Jarold Ramsey and Suzi Jones on Oregon Indian Folk Literature.

${ }^{11}$ Clarence Orvel Bunnell. Legends of the Klickitats: A Klickitat Version of the Story of the Bridge of the Gods (Portland, OR: Metropolitan Press, 1935), 6.
} 
As Bunnell narrates, God was so busy he forgot to give the Indians mouths, and these people who could not speak learned to smell, and to see beyond the river and deep into the forest. They became "adept hunters and expert fishermen; the women picked berries, dug camas and kouse and were excellent cooks but, not having mouths, of course no one was able to eat." Koyoda Spielyi, a spiritual entity with great powers, came to the Indians, cutting mouths of flint for them carved from the mountains. Then they could eat and sing, laugh and talk, and tell stories of Koyoda Spielyi, a being later known as the wily and wise, god-like Coyote. $^{12}$

Bunnell's retelling of the Indian stories describes a sequence of events that reflected the importance of human relationships with a forested, mountainous, and riverine landscape. At one time, the Columbia had become a great inland sea, and those who lived along its north shore harvested the forest and river resources, made bark canoes, visited, and traded. Twice yearly, in the springtime or early summer, and in the fall after the harvest, they met in mountain meadows, exchanging gifts and giving thanks to the Great spirit. Bunnell's description of place, inherited and adapted from native people, included an enchanted perception of a world in which “... all trees, animals and birds, in fact almost all things upon the Earth, were able to talk. ..." Through these tales the earth is viewed as a relational, interactive

\footnotetext{
${ }^{12}$ Bunnell, Legends, 3, 7-11.
} 
dwelling for all beings. ${ }^{13}$ Even the mountains could feel, and their passions changed the landscape:

After many, many years of peace and happiness had passed, a beautiful squaw mountain moved into a neat little valley between Pa-toe and Yi-east, who dwelt on the westerly shore of this vast inland sea. Like all beautiful females, she was fond of attention. Though she soon grew to love Yi-east, the lesser of the two mountains, she concluded that it would be great fun to make him jealous by flirting with big, good-natured Pa-toe.

... Both mountains fell madly in love with her. Heretofore, they had been the closest of friends, as all brothers should be. Now, however, they began quarreling over matters of little moment. . . At first they argued, growled and rumbled at each other. Next they began stomping their feet and threatening, finally becoming so wrought up and angry that they spat ashes and fire in the air and belched forth such great clouds of black smoke that the suns were hidden and all the Earth was in darkness.

They "discarded their beautiful white coats and painted their bodies and the surrounding country with streamers of liquid fire. . hurling great white-hot rocks through the darkness at each other." When they tired, the world was lifeless. Animals escaped or died. The people fled or hid in caves. The fight tore a hole through the mountains, releasing the waters of the great inland sea and a bridge remained over the big river. The forests were decimated, “. . . burned away, leaving only black snags and smoldering logs. .."14

These oral accounts of the "Legend of the Bridge of the Gods," indicate the significance and relationship of both forest and river to native peoples. Those who escaped the fiery mountains fled to "the more distant but friendly hills." With the forests, berries, camas, and game destroyed, Koyoda informed the people that only the river provided hope for escape from the decimated landscape. Koyoda and six

\footnotetext{
${ }^{13}$ Bunnell, Legends, 13-15.

${ }^{14}$ Bunnell, Legends, 16-18, 65.
} 
men headed toward the sea to find the lost fish. On the other side of the mountain range they found "a terrible sight." Water and rock covered the land, "piling up mountains of gravel, rocks and silt, eventually joining the Willamette and pushing it out of its banks." When the travelers finally encountered a village with a friendly host, they feasted on salmon, venison, and camas, and then Koyoda drove the salmon back up the river to feed his people. And eventually "the scars of that great battle were worn away or hidden by the dense forests." 15

These cultural memories are clearly grounded in historic events and contribute to sense of place in the Gorge, yet not so long ago geologists claimed a land bridge across the Columbia would have been impossible. By the 1970s, the catastrophic origins of the Columbia Gorge had become a generally accepted scientific explanation. More recently, scientific experts determined it likely that the Bonneville Landslide shoved the Columbia River off of its course. The landslide may very well have created a traversable land bridge, and blocked salmon migration. Scientists say that as the water rose behind the dam, a huge lake that drowned thirty-five miles of fir forest would have stretched as far east as Arlington, 100 miles away. It would have taken at least two years for the water to rise to the top of the dam, and when it did it would have caused a massive catastrophic flood extending as far as Troutdale. Evidence of such a flood is visible in Columbia River sand found in backwater deposits on the Sandy River. According to hydrologist Thomas Pierson, two floods may have been caused by the breaching of

\footnotetext{
${ }^{15}$ Bunnell, Legends, 20-21, 23, 29, 39, 42.
} 
landslide-dammed lakes, one about 450 years ago, another around 1,600 years ago.

Radiocarbon dating from drowned trees have recently indicated both dates are likely. ${ }^{16}$

The cultural memories imbued by such legends that remain strong in native belief systems and which are retold by Ella Clark and Clarence Bunnell, have seeped through the ages into contemporary American regional culture. Where once a bridge of mud, rock, and debris dammed the Columbia, the "Bridge of the Gods," built in 1925, crosses the river near Bonneville Dam at the Oregon town of Cascade Locks. The legend and its contemporary namesake are evidence that place names, myths, and the scientific record can serve to link oral tradition to science, thus connecting the landscape of the Gorge in space and time through a cross-cultural relationship with place.

\section{Rivers, Forests, and the People of the Rapids}

Today on the northern shore of the Columbia, the towns of southern Skamania County, Washington - Skamania, North Bonneville, Stevenson, and Carson - lie along a thirty-mile stretch of the river. Carson is tucked just a few miles northeast from Stevenson at the edge of the forest, and the town of Cascade

\footnotetext{
${ }^{16}$ Hill, "New Look," 2-4. Until recently, based on previous radiocarbon dating, scientists believed that the Bonneville Slide occurred around 1100 A.D. However, puzzled by the existence of submerged trees visible in the Columbia River until the 1930s, geologists Patrick Pringle and Robert Schuster conducted radiocarbon testing on a Douglas fir that had been buried by the landslide and uncovered during the building of the Second Powerhouse at Bonneville Dam. The radiocarbon tests indicated dates between 360 and 410 years, with an 80-year margin.
} 
Locks, Oregon stands almost directly across the Columbia from Stevenson. ${ }^{17}$ In this part of the gorge, a distinct awareness of the damp, green, mountainous landscape affects the human consciousness. Tall firs line the roadside, the air is damp, light wanes, and moss and fern nearly creep onto the highway. Where trees have not been cleared, the forest still edges up to the Columbia. Smaller mountains and hills flank the Cascade Range, creating valleys where tributaries of the Columbia cut to the mightier river.

The Wind, a river that drains a 225 square-mile watershed, is one such tributary bordering the Cascade Crest. It is the sort of bioregional division that historian Dan Flores recommends as a window to larger patterns of historical change. The Wind enters the Columbia at the Bonneville Pool, 154.5 miles from the sea. From its headwaters the Wind River ranges through high to low elevations. Winters in the Wind River Basin are cool and moist and summers are dry. To the northwest and southeast, portions of the watershed are steep, while the northeast McClellan Meadows area, Trout Creek, and the middle Wind River are composed of benchlands, where steep slopes rise above and below shelflike areas of rock. Twenty-five million years of volcanic and glacial activity have shaped the rock and soil of the valley. In some places, like Indian Heaven, a smooth, shaved

\footnotetext{
${ }^{17}$ Skamania to North Bonneville is 10 miles. North Bonneville to Stevenson is three miles. Stevenson to Carson is a little over three miles. Stevenson to Bingen/White Salmon is 22 miles.
} 
landscape of alluvial soils formed by flood deposits and glaciers comprise the Wind's floodplain. ${ }^{18}$

The vast forests of the Columbia's north shore drew many people to its banks, first indigenous residents and later emigrant settlers. The forests played a major role in the use, perception, and lasting sense of place on the river's north shore. During the late eighteenth and early nineteenth century contact period Sahaptin-speaking Klickitat, Yakama, Taitnapum and related bands used the upland forest resources in conjunction with Salish-speaking Cowlitz and Upper-Chinookan Cascades and Wishram. From Five Mile Rapids downstream to the Lewis River, the Chinookan speaking Wishram, Wasco, White Salmon, Cascade or Watlala, Multnomah, and Clackamas groups lived along the big river. During the historic period the Chinookan White Salmon people lived in villages extending for approximately thirty miles, from ten miles below The Dalles nearly to the Cascades on the south side of the Columbia. White Salmon villages identified by anthropologists Leslie Spier and Edward Sapir in the 1930s existed as far west as Underwood, Washington. Cascades villages began at sk !ema'niak, now known as Skamania. Prior to smallpox epidemics of the 1770 s, it is likely that Chinookan settlements existed in between, where the communities of Stevenson and Carson now stand. Spier and Sapir estimated the population along this stretch of the river in the thousands at Wishram, White Salmon and Klickitat, and Cascades villages.

\footnotetext{
${ }^{18}$ U.S.D.A. Department of Agriculture, Forest Service, Wind RiverBasin Watershed Analysis: Gifford Pinchot National Forest (Gifford Pinchot National Forest: Wind River Ranger District South Skills Center, April 1996), I-2.
} 
Villages housed anywhere from twenty-five to four hundred people, with the population of lxaxwa'lukl, two miles below sk !ema' niak, estimated at near $1,000 .^{19}$

The Chinookan Cascade Indians who once called themselves the Gahl'xishachk, "people of the rapids, ${ }^{20}$ lined the north shore of the Columbia where Bonneville Dam now backs water over the once-famous rapids. These were the people described by Lewis \& Clark as the Shahala Nation, composed of the Wahlala (Watlala) at the Upper Cascades, the Clah-Cleh-Lah near present-day Bonneville Dam, and the Wah-Cleh-Lah near Beacon Rock. During historic times, the Wind River Valley was part of the territory of the Cascade Indians, people who controlled transportation from the Columbia Plateau and the Cascadian forests through the gorge to the sea in the late eighteenth and early nineteenth centuries. The Cascade Rapids was both a transportation barrier and a major Indian fishery. During the winter Cascade Indians lived in at least three, and probably more,

\footnotetext{
${ }^{19}$ Richard McClure and Cheryl Mack, with contributions by Terry L. Ozbun, John L. Fagan, and Gary C. Bower, "Data Recovery Excavations at the Trout Creek Archaeological Site (45SA222), Gifford Pinchot National Forest (Vancouver, WA: Gifford Pinchot National Forest Heritage Program, August 1999), 15; Leslie Spier and Edward Sapir, Wishram Ethnography, University of Washington Publications in Anthropology, Vol.3, No. 3 (May, 1930), 160-164,167; Cheryl A. Mack "Past Human Uses of the Wind River Watershed" (Vancouver, WA: Gifford Pinchot National Forest, Wind River Ranger District South Skills Center, October, 1995), 14; Robert T. Boyd, "The Introduction of Infectious Diseases among the Indians of the Pacific Northwest, 1774-1874" (Ph.D. diss. University of Washington, 1985), 81-90.

${ }^{20}$ Chuck Williams, Bridge of the Gods, Mountains of Fire: A Return to the Columbia River Gorge, Introduction by David R. Brower (San Francisco and White Salmon: Friends of the Earth \& Elephant Mountain Arts, in cooperation with Columbia Gorge Environmental Center, 1980), 50.
} 
permanent villages above and below the present-day town of Skamania and one on the south side of the river. ${ }^{21}$

The place names of the Cascade Indians reflect their use of place. Eugene Hunn points out that "human languages. . . provide people with a consistent and powerful means of grasping the nature of the world in which they live." Unlike the Euro-American naming process in which a place name might reflect who owned property, a person's city of origin, or other imposed ideas, native people named places according to "where things happened."22 Sk !ema'niak, meaning "swift waters" ${ }^{23}$ identified the region. The Cascade fishing stations, Icapskilauya, "kingfisher," and lilxigakdix, "eddy comes back up," referred to places where people from around the region came to harvest salmon and sturgeon. Native people operated within dynamic social and political boundaries. Groups reserved common hunting and gathering territory by usufruct rather than through private property rights. Family ties to other groups and the fluctuations of the Columbia made sharing fishing sites necessary and desirable, with fishing and drying sheds located along the lowlands of tributary rivers. Native peoples held fishing stations in common, directed by a chief or headman. Families moved along the rivers during fishing season, interspersing fishing with hunting and gathering in higher elevations and following resource availability in the nearby forests and mountains. Sahaptin,

\footnotetext{
${ }^{21}$ Spier and Sapir, Wishram, 164, 167; McClure \& Mack, "Data Recovery," 15; Gary E. Moulton, The Journals of the Lewis \& Clark Expedition, March 23-June9, 1806, Vol. 7 (Lincoln: University of Nebraska Press, 1991), 96-97.

${ }^{22}$ Eugene S. Hunn with James Selam and Family, Nch'i-Wána "The Big River": Mid-Columbia Indians and Their Land (Seattle: University of Washington Press, 1990), 78, 93.

${ }^{23}$ Spier and Sapir identify this word as "running by her continually," 167.
} 
Salish, and Chinookan people married and traded with one another, using the big river, its tributaries, and the rich upland forest resources to sustain their way of life.

The seasonal round followed by groups along the Columbia shore, both north and south, marks them as forest people as well as river people. They moved between rivers and mountains, fishing, gathering plants and berries, and harvesting wood for items ranging from canoes to utensils. ${ }^{24}$ An encyclopedic knowledge of the land sustained them through their seasonal round. Winter offered time for tool construction and maintenance in the valley lowlands. At this time of the year, Indians constructed dipnets, told stories, and shared information about the past year's harvest and planned the year to come. Springtime brought the all-important salmon upriver, but first women worked to harvest the year's supply of roots within a carefully planned scheduled that adhered to land cycles. Women harvested bitterroot and men caught fish in the spring only after performing the proper thanksgiving rituals. As floodwaters covered fishing sites along the Columbia, the people followed the land and the resources upstream into the Columbia's tributaries where the fish migrated in the early summer and various roots reached the proper stage of maturity for harvest. During the summer groups gathered together in the Cascade foothills where gambling and horseracing complemented gathering an

\footnotetext{
${ }^{24}$ Spier and Sapir, Wishram, 160; McClure \& Mack, Data Recovery, 14. Spier \& Sapir say the Wishram "hunted and sought plants on the higher country directly back from the river to the watershed, that is, on the southern slopes of Mount Adams and the so-called Klickitat Mountains."
} 
abundance of vegetal foods, especially camas, in the early summer and a multitude of berries later in the season and into the fall. ${ }^{25}$

Archaeologists have identified more than forty-five prehistoric sites within the Wind River watershed situated in a variety of environmental settings from ridgelines to meadow edges. For thousands of years native people have used the valley for many purposes. Beginning approximately 7,000 years ago native people hunted and made tools in the valley. To the present day they collect huckleberries, beargrass, cedar bark, cedar roots, and medicinal plants. A total of 912 peeled cedar trees have been identified within the Wind River watershed, the majority along the western and southern base of Red Mountain. Other peeled trees include hemlock, used for food as well as basket making. The mouth of the Wind River, with its two basalt outcroppings, provided a favorite fishing site until inundated by Bonneville Dam in 1938. Similar fisheries on other Columbia tributaries, and access to upland forest resources made the north side of the Columbia among the most populated in the northwest. ${ }^{26}$

Exploring indigenous forest use through accounts of explorers, trappers, early settlers, and ethnographers allows one to gain a haptic sense, a feeling for the forested riverine landscape in which the biomes are intimately connected through human activity and ecology. As Lewis \& Clark descended west along the

\footnotetext{
${ }^{25}$ Hunn and Selam, Nch'i-Wána, 91, 119-130..

${ }^{26}$ Minor, Archaeological Testing at 45SA16, 2, 15; Alexander Ross, Adventures of the First Settlers on the Oregon or Columbia River, ed. with historical introduction and notes by Milo Milton Quaife (New York: Citadel Press, 1969), 120; Roberta Ulrich, "Empty Promises, Empty Nets" Oregon Historical Quarterly 100, 2 (Spring 1999), 139,142,146; Hunn and Selam, Nch'i-Wána, 93-94. Hunn refers the reader to Spier and Sapir for Upper Chinookan fishing practices; Spier \& Sapir, 165, 175; Mack, Human Uses, 5; Watershed Analysis, III-80-140-141.
} 
Columbia River in October 1805, they carefully noted a change in environment. The party first commented on the scarcity of wood on the dry east side at The Dalles. As they moved toward the sea, they observed the way in which forests began to permeate the landscape. Clark first recorded a few small pine "on the tops of the high hills and bushes in the hollers" near the John Day River. On the evening of October 21, 1805 the explorers purchased wood "at a high rate" from native inhabitants to boil their dinner of fish and dog meat, and the following morning had barely enough wood to cook breakfast. When they reached The Dalles, the explorers encountered wooden houses made of timber transported from downriver. These were the first wooden dwellings "in which Indians have lived," wrote Clark "Since we left those in the vicinity of the Illinois." As the party neared the Upper Cascades from the east, the landscape changed from "broken Country thinly timbered with pine and white oake.... very rocky and hilley --" to "High Mounts on each Side, rugd and covd. with a variety of timber Such as Pine Spruce Seder Cottonwood Oake." At the entrance to "New Timbered River," later known as Cruzatte's River by the party, and later the Wind by American settlers, Clark described the explorers' first glimpse of Oregon ash and red alder, "verry large" trees. " At New Timbered River, where the explorers encountered the flora of the westside for the first time they dined in grass and fern-covered bottomlands, and noted a transition to the westside ecotone. In 1811, Alexander Ross described the area a short distance from the Cascades: "Generally speaking," he wrote, "the 
whole country on either side of the river, as far as the eye could reach, presented a dense, gloomy forest." 27

Wood and plants from the "gloomy forest" provided a resource foundation for the salmon-based subsistence of regional Indians. Hunting deer, elk and other game, as well as gathering much needed materials for production of household items, canoes, tools, and even clothing took native peoples into the forests, while fishing and trading brought them back to the river. Although salmon provided the root of spiritual and economic relations, wood, food, and plant products from the nearby forests contributed significantly to the river lifestyle, shaping a sense of place. First foods ceremonies took place as the land awakened from its winter sleep. Hailed by ceremonies before salmon arrived in the spring, the first greens poked through the ground. Various "celeries" such as bare-stemmed and gray's lomatium sprouted on the eastern low-elevation hillsides of the Cascades, while salmonberry and horsetail shoots burgeoned, and cow parsnip and water parsley budded on the west. ${ }^{28}$

From British Columbia to northern California, native people welcomed spring salmon through ceremonies as a symbol of rejuvenation. A shaman conducted the first salmon ceremony, ensuring the coming salmon run. He first cut off the two flanks of the fish, leaving the head, backbone, and tail in one piece. He then inserted bits of dry cedar along the flank to hold them open, cooking the fish

\footnotetext{
${ }^{27}$ Gary E. Moulton, The Journals of the Lewis \& Clark Expedition, July 28-Nov. 1, 1805, Vol. 5 (Lincoln: University of Nebraska Press, 1988), 315, 339, 333, 342, 349, 355-356, 358; Ross. Adventures, 117.

${ }^{28}$ Hunn and Selam, N'Chi W'ana, 107-108; McClure \& Mack, Trout Creek, 20.
} 
on a bed of heated stones atop a thick layer of choke cherry leaves covered with mats. When the fish had been cooked and prayers said, each member of the group received a small piece of salmon. This springtime ceremony came at the beginning of a season of preparation for the following winter. During the summer and falls runs, Indians along the river dried and pulverized salmon for commercial purposes, placing the catch in baskets for winter and baling it for trade to downriver markets. William Clark provided evidence of the fishery's productivity in October 1805 when he noted approximately ten thousand pounds of bundled salmon at The Dalles. $^{29}$

The relationship between forest and river can be explored by examining the methods native people used the forest to access important river resources. Indians at The Dalles and Celilo Falls fashioned cedar canoes from westside forests. Other wood products complemented boat construction, including smearing fir pitch on canoes to smooth the surface before burning. Indians carved bailers and paddles from maple, ash, and oak..$^{30}$ Fishing technology, especially, reveals the importance of forest resources to the river peoples. In 1812, Astorian Robert Stuart described fishing platforms that rose above the river:

by binding two long but slender trees together with strong withes, next tying a stout piece of wood across the two former, from 4 to 6 feet below where they are bound together. --thus arranged, this preparation is set erect in the water, when the two ends of two slabs, several inches thick and from 20 to 40 feet long, are laid on the cross piece of the two uprights, so as to reach 6 to 8 feet beyond them, with the other ends resting on the rocks along the

\footnotetext{
${ }^{29}$ Spier \& Sapir, Wishram, 248-249; Moulton, The Journals, Vol. 5, 335.

${ }^{30}$ Spier \& Sapir, Ibid, 186-187.
} 
waters edge; at the farther extremity are a few of their boards from slab to slab, on which the Fisherman stands plying his scoop net. ${ }^{31}$

At stations that did not require staging high above the river, men placed wooden wedges at the foot of upright rocks. A man could slide down a wooden pole, and using the wedge for footing, haul in his catch.

Use of wood and plant products solidified the material relationship between forest and river, thus forging a sense of place. Native people created nets, spears, gaff hooks, fish traps, and weirs from wood products. Nets, the most common fishing apparatus, combined wood, plant material, and bone obtained from nearby and upland forested areas. Balsam pine provided the twelve to fifteen foot bent poles of bark fishing nets. Fishermen made dip nets with maple sapling handles attached to wooden rings fastened by oxhorn. They wove the net $-\mathrm{a}$ four-foot pouch fastened onto the hoop - of fibers from trees found extensively along the river. After placing dipped salmon on the river's bank, a man used an undecorated 15-inch wooden club to kill it. Flax fiber, obtained from the forest, provided nets to harvest eels, suckers, chubs, and smelt. Seine nets of flax fiber and rope were fastened with stone sinkers. Nets were fabricated with gauges made of flat slabs of elkhorn. The gauges that held the nets were often carved with human faces, salmon, sturgeon, seal, and the heads of various birds reflecting significant elements of the landscape. Indians set basket traps and weirs made of hazel or

\footnotetext{
${ }^{31}$ Stuart quoted in Stephen Dow Beckham, "This Place is Romantic and Wild": An Historical Overview of the Cascades Area, Fort Cascades, and the Cascades Townsite, Washington Territory, Heritage Research Associates Report No. 27 (Eugene: Heritage Research Associates, April 10, 1984), 21.
} 
willow twigs on creeks and smaller rivers such as the Wind, and wooden pens captured salmon at shallow falls. Fishers also constructed spears of forest and mountain products, setting stone points in wood or deerhorn connected by sinew to wooden shafts lashed with cherry bark. ${ }^{32}$

Wood and plant products permeated the living space of river Indians, with westside forests providing building material of now-scarce cedar for upriver homes as far east as The Dalles. Near Bonneville Dam, at the village Lewis \& Clark referred to as Clah-Cleh-Lah, native people lived in large permanent 35 to $50 \mathrm{foot}$ long mat lined structures with huge sunken fireplaces. Circular semi-subterranean lodges, built with poles were covered with tule mats, grass and dirt or cedar bark. Lewis described these movable houses as "most generally built with boards and covered with bark. Some of an inferior or more temporary cast are built entirely of cedar bark, which is kept smooth and extended by inserting small splinters of wood through the bark crosswise at the distance of 12 or 14 inches asunder." ${ }^{\prime 33}$ The portable houses allowed native people to move their homes to the locale of resources such as salmon at The Dalles and the Upper Cascades. The Indians at the Cascades also built other more permanent structures. In some cases native people sunk pit houses about eight feet into the earth, covered the strong timbers with dirt, and placed an opening at the top that served as both chimney and door. ${ }^{34}$

\footnotetext{
${ }^{32}$ Spier \& Sapir, Wishram, 175-178; Beckham, This Place, 22.

${ }^{33}$ Moulton, The Journals, Vol. 7, 107; Alan Skinner, Clah-Cleh-Lah: An Archeological Site at Bonneville Dam, Washington, Environment Consultants, Inc. (Portland, OR: U.S. Army Corps of Engineers, July 1981), 1, 5 .

${ }^{34}$ Moulton, The Journals, Vol. 5, 329.
} 
Abundant forest resources served many purposes other than providing housing and fishing apparatus. Fungi and tree saps created red, yellow, black and brown paints sometimes used on carved effigies and monuments made of timber. Women made cosmetic face paints from a warty fir tree fungus. They wrapped the fungi in leaves, buried, and then roasted it until the fungi became red and turned to powder. After mixing with deer tallow and kneading until no longer greasy, women put the substance on their faces for sun protection and as decoration. During the summer Chinookan women wore short, mid-thigh length cedar bark skirts, made pliable by beating strips of the wood with sticks. Women complemented their summer clothing of tanned deer and mountain goat hide with conical basket hats of mountain grass. Children's and men's clothing also reflected the use of forest resources. Breech-clouts from small animals such as raccoons, and winter coverings for all, were made of fur. Native people used bear, raccoon, deer, wolf, coyote, and mountain goat pelts for various purposes, from leggings to blankets, to caps and mittens. During the winter, moccasins of tanned leather stuffed with grass warmed the feet. ${ }^{35}$

Although most Cascade Indians spent the winter along the Columbia River's banks, the upland forests to the north remained significant to the indigenous sense of place. From late fall until early spring people hunted in the forests around the southern spur of Mount Adams and within the Cascade valleys. When Lewis \& Clark purchased two ornamental sheepskin caps, the Clahclellahs, whose village

\footnotetext{
${ }^{35}$ Spier \& Sapir, Wishram, 207-208; Beckham, This Place, 13.
} 
lay near present-day Bonneville Dam, informed them that the caps came from the abundant herds in the nearby mountains. Both explorers noted snowshoes among all the groups along the river, and commented about winter deer hunting. These snowshoes were made of a hoop of hazel, dogwood, or oak netted with one inch rawhide strips of bear or deer with the hair remaining. Hunting deer and elk, often sheltered under heavy timber groves far back in the mountains during the winter, contributed significantly to dwindling food supplies. Explorers' accounts and native tales frequently refer to forest animals, reflecting the important resource significance between river Indians and the forest. A wide variety of animals provided year-round meat and fur: deer, elk, bear, squirrel, grouse, duck, rabbit, beaver, otter, raccoon, mountain goat, mountain sheep, wolf, fox, and cougar. Bear hunting took place during late summer or fall since the bear, like humans, went high in the mountains to harvest huckleberries, blackberries, and hazel nuts. ${ }^{36}$

Household items, foods, and cooking utensils used by Chinookan people also reflect the haptic sense of the forested riverine environment. Natives on the north shore of the Columbia used kitchen utensils of horn and wood, and cedar kettles for cooking and eating. Wood played an important role in food preparation and Indians often used specific woods for different foods. For example, lamprey eel were skewered on a tasteless wood obtained from the mountains. Like sentient beings, living forest products held spiritual value for native people. Fir bark, placed on top of large logs, was used extensively in hearths. The name Indians

\footnotetext{
${ }^{36}$ Moulton, The Journals, Vol. 7, 112, 113; Spier \& Sapir, Wishram, 181, 187; McClure \& Mack, Data Recovery, 21.
} 
used for the fir log, "husband of the bark," reflected a sense of a connectedness between the bark and the log - living beings in the non-human world. ${ }^{37}$ Alexander Ross described an "Indian feast" at the Cascades in 1816 that demonstrated the importance of forest products to native lifeways:

The first thing that attracts the attention of a stranger, on being invited to a feast in these parts, is to see seven or eight bustling squaws running to and fro with pieces of greasy bark, skins of animals, and old mats, to furnish the banqueting lodge. . . the reader may picture to himself our friend seated among the nobles of the place, his bark platter between his legs, filled topheavy with the most delicious mélange of bear's grease, dog's flesh, wappatoes, obellies, amutes, and a profusion of other viands, roots, and berries. $^{38}$

In late spring, people moved their fishing villages to the mid-elevation forests, around 1,100 feet above sea level, to harvest many of these resources along Columbia tributaries like the Wind and White Salmon Rivers. Spring fishing combined with gathering greens, and maturing plants took people higher into the mountains to gather nuts, berries, beargrass and roots throughout the summer. The Kalamát Meadow, later identified as the "Indian Racetrack," was a center for social activity. Kalamát means "yellow pond lily," a flower found unexpectedly at this high elevation place where women found the best berrying and camas harvest grounds. While women visited with one another, men traded, gambled, and raced horses throughout the summer. Chinookan women collected other plants and roots on the slopes of the Cascades. Roots included camas, among the most important

\footnotetext{
37 Spier \& Sapir, Wishram, 179, 185.

${ }^{38}$ Alexander Ross, Fur Hunters of the Far West. ed. Kenneth Spaulding (Norman: University of Oklahoma Press, 1956), 100.
} 
bulb foods found on eastern and western slopes, and the roots of the cattail, bracken fern, horsetail, thistle, and lupine from the mountain range's western slopes. ${ }^{39}$

Women gathered cedar roots that grew along the edge of the ground in the summer, and dried and split them to make cedar-root gathering baskets. They first soaked the fine roots, then wrapped leaves of beargrass, a bushy plant with long thick spindly green leaves found high in the mountains, around the root to bind the basket. Colorful and artful containers of various sizes, colors, and uses were made with dyes - alder bark for red, Oregon grape for yellow, and mud-soaked beargrass for black and brown. Women used the baskets of cedar bark root and prickly green bear grass for cooking, carrying water, and for gathering the sweet purple huckleberries that they dried and mixed with the fall catch of salmon. ${ }^{40}$

\section{Reshaping the Ecological and Social Landscape}

Sense of place in westside forests during the nineteenth century included smoke rising from a burnt over landscape, and both short and long-term ecological impacts of fire. When the first Euro-Americans entered the Columbia River Gorge, they encountered a landscape consciously shaped by native people. In April 1806, Captain Meriwether Lewis noted fir recently blackened by fire, which "discharged considerable quantities of rozin" near Brant Island, in what is now the eastern part

\footnotetext{
${ }^{39}$ McClure \& Mack, Data Recovery, 20.

${ }^{40}$ Hunn and Selam, $N$ 'Chi W'ana, 94; "Maggie McLaughlin Recounts Childhood in 1968 Interview" in Homer and Alice Townsend, Skamania: A Columbia River Gorge Community in the 1920 s (Homer and Alice Townsend, 1986), 22; McClure \& Mack, Data Recovery, 21; Spier \& Sapir, Wishram, 182-183; Moulton, The Journals, Vol. 5, 363.
} 
of Skamania County's North Bonneville. Fire enhanced resource productivity and shaped space for human use. According to anthropologist Robert Boyd, Indians consciously used fire to manipulate the environment. Indians set fires for many reasons including creating meadows to provide animal forage, driving deer to a certain location, and for seed gathering. Indians also practiced semi-agricultural management techniques. They intentionally burned root plants such as camas and lomatium and replanted unsatisfactory roots. They also regularly burnt over meadows to stimulate huckleberry production. ${ }^{41}$ In 1849, U.S. Army Lieutenant Osborne Cross described the impact of fire on a changing landscape, as his party moved from The Dalles toward the Cascades:

Mount St. Helens was very plainly seen for the first time this morning to the north, though much hidden by mountains in that direction. Since my arrival the smoke has been so dense as to exclude the scenery in the immediate vicinity, but the top of this mountain, rising over the neighboring mountains, could now be plainly seen capped with snow. This view, with that of Mount Hood to the west, the mountains covered with pine around us, and the hills to the east destitute of wood, gave us a new picture...

Cross' sense of fire-shaped space continued at the Cascades:

The banks of the river about here are extremely rocky, [while] the mountains are high and steep and thickly covered from their base to the top with pine, fir, and hemlock. The timber on the right [north] bank of the river is much better than on the left, as the mountains are not so high and the land more rolling. Much of the timber has been destroyed by fire along this part of the river, as it [has been] through [to] the Pacific. ${ }^{42}$

\footnotetext{
${ }^{41}$ Moulton, The Journals, Vol. 7, 98, 101, n. 10; Robert Boyd, "Introduction" in Robert Boyd, ed., Indians, Fire and The Land in the Pacific Northwest (Corvallis: Oregon State University Press, 1999), 12-14.

${ }^{42}$ Raymond Settle, ed., The March of the Mounted Riflemen: First United States Military Expedition to travel the full length of the Oregon Trail from Fort Leavenworth to Fort Vancouver, May to October, 1849, as recorded in the journals of Major Osborne Cross and George Gibbs and
} 
Reference to fire in the Northwest is common in the historical literature. Captain George McClellan and James G. Cooper, traveling through the Cascades in 1853 for the Pacific Railroad Survey, identified many burnt over areas that shaped resource-productive prairies. McClellan and Cooper traveled through the low divide separating the Lewis and Wind river drainages, from Fort Vancouver 40 miles west of the Cascades on the Columbia bottomlands, to McClellan Meadows, north of the rapids. As the moved through the region, they noted extensive tracts of burned over forest, Indian lodges and gathering places in sites clearly manipulated by fire. Nearing an open space, later called McClellan Meadows, to the northwest of the Indian racetrack in what is now the Gifford Pinchot National Forest, the survey party traveled through "a burnt forest with but little living vegetation." They camped at this small meadow "full of excellent grass" describing it as "a small pretty prairie where there were a number of old Indian huts. ${ }^{, 43}$ Chequoss, near the crest of the Cascade Mountains east of Red Mountain was surrounded by hills "almost all burnt over," with two small ponds and a well providing water for both humans and animals. In the vicinity were "some 20 lodges of Indians."

The acrid smell of seasonal forest burning shaped the perception of place as much as the sound of twittering birds or running water. Lightning strikes and

\footnotetext{
the official report of Colonel Loring (Reprint. Originally published: Glendale, CA: Arthur H. Clark Co., 1940, Lincoln: University of Nebraska Press, 1989), 249, 262.

${ }^{43}$ Mack, Past Human Uses, 8; Helen H. Norton, Robert Boyd \& Eugene Hunn, "The Klickitat Trail of South-central Washington," in Boyd, Indians and Fire, 87-88.
} 
volcanism also caused fire, but the contour of the landscape clearly reflected intentional human manipulation. ${ }^{44}$ Cooper speculated on the origin of the many mountain prairies:

It is certain that the Indians have always been in the habit of burning off these prairies annually to kill the young trees and cause a fresh growth of grass. . . they also derived one of their principal vegetables from these same prairies and still, the whole tribe resorts to them and encamps during June and July to gather the kamass root. . I I cannot otherwise than by this agency of man, account for the existence of many prairies whose outline is as sharply defined by the unbroken edge of forest as if carefully cleared for the farmer, every stump dug out, and the ground levelled - raked smooth, and sown with grass and flowers. ${ }^{45}$

Fire shaped the landscape, creating human-used space and a sense of place. The origin and outcome of managed fire was closely associated with the berry harvest. Indians often used fire to maintain productive open fields. They set berry-drying fires in the fall to facilitate the following year's late summer harvest and so that rain would quench the flames. Berries were either dried on tule mats or on long racks above smoking log fires built by women. During the summer women often stayed at mountain camps, while men fished on the Columbia and tributaries such as the White Salmon and Wind rivers, returning with their harvest for women to dry and store. When the harvest ended, women often left berry-drying fires to spread, with autumn rains extinguishing them. These fires also facilitated growth of other important early succession plant foods, such as nuts, Oregon grape, serviceberry, bracken fern, fireweed, salmonberry and other berries. ${ }^{46}$

\footnotetext{
${ }^{44}$ Norton, Boyd, \& Hunn, Indians and Fire, 88, 69.

${ }^{45}$ Norton, Boyd, \& Hunn, Indians and Fire, 68-69.

${ }^{46}$ Mack, Past Human Uses, 5; Norton, Boyd, \& Hunn, Indians and Fire, 79-80, 71-72.
} 
Spring, summer, and fall men and women lived and labored at the many significant upland and low elevation sites in the Wind River Valley. Although many groups used the mountain meadows and valleys of the forests near Mt. Adams, the Cascades Indians of the Columbia's north shore had primary usufruct rights to the Wind River Valley. The Trout Creek site (1080-foot elevation) was one of several throughout the drainage used as temporary base camps for seasonal hunting and. Hemlock Lake was likely a base camp for seasonal hunting and gathering. Native people also collected a variety of rocks from stream gravels, most commonly chalcedony or chert and sometimes jasper, for cutting and scraping tools and for projectile points. At the headwaters to Paradise Creek, a 3,200 foot elevation Wind River tributary, native people collected, heated, and treated jasper pebbles for transport. Over 40 additional sites of human activity have been identified in the Wind River Basin, demonstrating intensive human use of the forested basin. ${ }^{47}$

The human landscape of the Cascades region and the Wind River Valley underwent a rapid and catastrophic shift by the mid-nineteenth century as biological and social forces combined to shape a new geography of power on the Columbia. Explorers and trappers such as Lewis and Clark, Astor's overland party, and David Thompson portaged around the dangerous rapids, learning quickly that they must pay tribute to the resident natives or encounter resistance. Meriwether Lewis complained about the Cascade Indians. "These are the greates[t] theives and

\footnotetext{
${ }^{47}$ Mack, Past Human Uses, 3-4; Personal Communication with Forest Archeologist Rick McClure, January 25, 2004.
} 
scoundrels we have met with," wrote Lewis on April 11, 1806, as the party prepared to trek the portage, "two thousand eight hundred yards along a narrow rough and slipery road." Conflict ensued when two Cascades men stole an axe from the government party, only to have it immediately wrested from them. The Lewis and Clark party threatened to kill anyone who opposed them further, both leaders commenting that only the size of their party kept the travelers safe. ${ }^{48}$

Similar incidents occurred many times during the early nineteenth century as the Northwest fur trade prospered. While whites viewed the natives at the rapids alternately as impediments and sources of assistance, it is likely that this question posed by an Indian man upriver at The Dalles in 1814 typified sentiments at the Cascades as well: "How long are the whites to pass here, troubling our waters and scaring our fish, without paying us?" Geographer Cole Harris refers to strategies of power used by whites during this period of sovereignty and trade manipulation. Distant powers claimed possession of land, while imposing certain conditions on trade relations. For example, whites demanded their definition of "good conduct" on the part of natives. Indians should not attack or steal from whites, or "swift, drastic retaliation would follow... Accompanying this threat was the decorum of the fur trade: a little tobacco, a little rum, a handshake from the Great Chief." In April 1806 at the Cascades, for example, William Clark exchanged tomahawks with a chief of the Clah-Cleh-Lahs, in addition giving him a peace medal to maintain accord between groups. Although these kinds of negotiations took place

\footnotetext{
${ }^{48}$ Beckham, This Place, iii; Spier \& Sapir, Wishram, 167; Moulton, The Journals, Vol. 7, 104-106, 109.
} 
repeatedly, by 1824 when the Hudson's Bay Company established a fur trade post approximately thirty-eight miles west of the Cascades at Vancouver, power relations at the rapids had become stabilized. This occurred not only through affable trade relations and better weapons on the part of Euro-Americans, but most significantly through catastrophic changes in the native population. ${ }^{49}$

The major shift in power relations that took place during the first half of the nineteenth century in the Columbia River Gorge stemmed partly from what historian Alfred Crosby calls biological and ecological imperialism, an almost invisible form of conquest that assisted European peoples in the physical and cultural takeover of the Americas. Ecological and biological imperialism took various forms, reshaping the human and biological landscape by introducing nonnative species and more insidiously, by introducing unfamiliar germs. According to Robert Boyd, "depopulation on the Lower Columbia was truly fearsome." When Euro-Americans reached the Pacific Northwest, they encountered a human landscape already reshaped by pestilence. Lewis and Clark noted the pock-marked face of a young Chinook woman in 1805 , speculating that smallpox had swept the Northwest Coast approximately thirty years earlier. Other accounts validate a smallpox visitation from the Northwest Coast to the Columbia Plateau sometime between 1769 and 1780, and again near the turn of the century. At the Cascades of

\footnotetext{
${ }^{49}$ Ross, Adventures, 119; Cole Harris, The Resettlement of British Columbia: Essays on Colonialism and Geographical Change (Vancouver, British Columbia: U.B.C. Press, 1997), 3; Moulton, The Journals, Vol. 7, 109.
} 
the Columbia, death and pestilence rapidly transferred control of the land and the river from indigenous to white. ${ }^{50}$

Before Washington even became a territory death, first in the form of smallpox and later through other diseases, became a major player in reconfiguring human populations on the Columbia's north shore. Between 1829 and 1833, a deadly fever swept through the indigenous population of the Lower Columbia River. Described as the cold sick, intermittent fever, or fever and ague, the disease decimated Indians near Fort Vancouver, Sauvie Island, and the Willamette Valley, reaching calamitously to the Cascades. ${ }^{51}$ Boyd has identified this plague, affecting both whites and Indians, as malaria. The disease of the 1830s reappeared annually, arising in mid or late summer and disappeared by winter for at least four consecutive years, thus the name "intermittent fever." Malaria, transmitted by mosquitoes, was unknown to native peoples of the Columbia until whites brought the malarial parasite to the Northwest where the damp west side of the Cascades and forested areas supported numerous lakes, swamps, and sloughs. A perfect landscape existed for breeding Anopholes malculipennis, the local malaria vector, with only a human carrier needed to start the plague of death along the river. "Fever and ague" hit hardest in the swampy waters and lakes of the Willamette Valley, at Fort Vancouver, and at Sauvie Island where the Cascade Indians traveled

\footnotetext{
${ }^{50}$ See, Alfred Crosby, Ecological Imperialism: The Biological Expansion of Europe, 900-1900 (London: Cambridge University Press, 1986); Boyd, Robert, The Coming of the Spirit of Pestilence: Introduced Infectious Diseases and Population Decline among Northwest Coast Indians, 1774-1874 (Seattle: University of Washington Press, 1999), 17, 28-29, 231; Moulton, The Journals, Vol. 5, 346.

${ }^{51}$ Boyd, Pestilence, 106.
} 
to trade for wapato and other goods. At its height of destruction during the early $1830 \mathrm{~s}$, the disease continued to kill throughout the decade.

The demoralization of the Cascades and other Chinookan bands brought many to Fort Vancouver, where they might find some refuge amidst demolished subsistence and cultural patterns. Some traveled to the lowland community to be near fur traders for commercial purposes and for services provided by the Catholic Church, ${ }^{52}$ where there was not only a hospital, but also the unlikely promise on the part of whites that they could be saved. Although whites died during these epidemics, most recovered, while Indians suffered "great mortality." Cultural medical practices exacerbated the situation. Even though the cause of malaria remained unidentified in the 1830 s, white people knew that quinine cured the disease. Indians treated the disease differently. Sweating and bathing cured a whole range of previously non-fatal native diseases such as colds, muscular aches, and "quick fevers." The sweathouse, a small, enclosed, circular structure, provided purification. Pouring water on hot rocks produced steam in the sweathouse, much like a sauna. To complete the purifying process, an ill Indian would jump into a cold stream, a deadly response in the case of malaria. Unfortunately, Indians would not accept the whites' treatment until much of the population had been wiped out, and by then it was too late. ${ }^{53}$

In 1805, Lewis and Clark noted a burial site of the Cascade Indians, eight sepulchers on the north bank of the Middle Cascades with eight-foot high by six-

\footnotetext{
${ }^{52}$ The Catholics arrived in Vancouver in 1836 and established a mission.

${ }^{53}$ Boyd, Pestilence, 106-108, 138-140; McLoughlin quoted in Boyd, Pestilence, 133.
} 
foot wide board vaults neatly containing human bodies with heads facing west, rolled in skins and lashed with cords. By 1811, Alexander Ross commented that the Indians living from the mouth of the Columbia to the Cascades were "said to be decreasing in numbers." Botanist David Douglas described the situation in 1832:

A dreadfully fatal intermittent fever broke out in the lower parts of this river about eleven weeks ago [late July] which has depopulated the country. Villages which afforded from one to two hundred effective warriors are totally gone, not a soul remains. The houses are empty and flocks of famished dogs are howling about while dead bodies lie strewn in every direction on the sands of the river. ${ }^{54}$

When merchant Nathaniel Wyeth traversed the Cascades the same year, bones overflowed the sepulchers. Wyeth noted that at the Cascades: "it is necessary to carry the boat and the Indians are all dead only two women are left a sad remnant of a large number their houses stripped to their frames are in view and their half buried dead this portage will be a hard job" ${ }^{, 55}$

When the army's skeptical Lieutenant Charles Wilkes surveyed the Columbia River in 1841, he reported that depopulation accounts were true: "for places were pointed out to me where dwelt whole tribes, that have been entirely swept off; and during the time of the greatest mortality, the shores of the river were strewed with the dead and dying." By Wilkes' account, only 150 Cascade Indians remained, the whole territory containing approximately 20,000 Indians. Although Wilkes' estimates were questionable, he correctly predicted the rapid transformation of the Lower Columbia from a native to a white landscape: "The

\footnotetext{
${ }^{54}$ Douglas quoted in Boyd, Pestilence, 122; Ross, Adventures, 95.

${ }^{55}$ Wyeth quoted in Beckham, This Place, 44.
} 
number of the latter has, however, increased very much since the year 1840, as many emigrants have crossed the mountains. The decrease of the red race is, no doubt, equivalent to the increase by immigration." 56 Two years later emigrants reported that the sepulchers near the Cascades "had rotted down, and the naked skeletons lay scattered over the ground." By 1851, another American migrant passing the Cascades described the Indian burial place where "bones of all sizes and ages were lying scattered about, the wagon crushing them as it passed along." 57

There are places where the impact of the physical environment is readily visible, and as Dan Flores asserts, where new conditions contribute to "the spiraling effect of endlessly re-creating place." The swift waters and grand forests of the place that would become Skamania County provide a distinctly regenerate space. At the Cascade Rapids, the natural and human equilibria have been intermittently punctuated by catastrophic change, both ecological and social. The Chinookan Cascade Indians who once called themselves the Gahl'xishachk, "people of the rapids, ${ }^{58}$ populated the north shore of the Columbia for millennia, actively shaping and responding to their environment to suit their needs. The rhythms of forest and river, in turn, affected cultural development, influencing the human response to the unfamiliar, relationships between groups, and the response to those who would

\footnotetext{
${ }^{56}$ McClure \& Mack, Data Recovery, 17; Charles Wilkes, U.S.N, Commander United States Exploring Expedition, 1839 to 1842, Columbia River to the Sacramento (Oakland: Biobooks, 1958), 30, 31.

${ }^{57}$ Moulton, The Journals, Vol. 5, 358-359; Johnson and Winter, Zieber, quoted in Beckham, This Place, 46.

${ }^{58}$ Chuck Williams, introduction by David R. Brower, Bridge of the Gods, Mountains of Fire: A Return to the Columbia River Gorge (San Francisco and White Salmon: Friends of the Earth \& Elephant Mountain Arts, in cooperation with Columbia Gorge Environmental Center, 1980), 50.
} 
soon appropriate their place. As James Ronda describes in "Coboway's Tale," lines of power and meaning changed as Americans "claimed space, squared it, walled it, and made it their own." 59 The means used to make such claims extended well beyond personal local relationships, springing as much from the national ideologies and values of those who next settled the Columbia's north shore as from the opportunities provided by the landscape itself. It is these processes that I will examine in the following chapters.

${ }^{59}$ James P. Ronda, "Coboway's Tale: A Story of Power and Places Along the Columbia," in Power and Place in the American North American West, ed. Richard White and John M. Findlay (Seattle: University of Washington Press, 1999), 7. 


\section{CHAPTER TWO: TRANFORMING THE COLUMBIA'S NORTH SHORE}

\section{Jeffersonian Democracy and the Pacific Northwest}

Late nineteenth century Euro-American settlement along the Columbia River took place in the context of national U.S. expansion that was underscored by agrarian ethics, a public land policy grounded in myth, and nascent market capitalism. For two centuries, evolving American land policy promoted placing native peoples on reservations to settle the West. Implementing settlement policies created what historian Patricia Limerick calls a "Legacy of Conquest,"1 a political and spatial takeover with multiple and lasting intersections between people and place. On the north shore of the Columbia River, first native people, then explorers, and finally American settlers intersected at various chronological points in a complex web of relationships to place, and to one another. By the late nineteenth century, a meeting between agrarian ethics, public land policy, and capitalist possibilities contributed to the way in which lands along the Columbia and in the Wind River Valley became bounded and claimed as American soil. This process of conquest and settlement demonstrates Dan Flores' concept of the recreation of place, and how a web of policy, ideology, and individual and community action contributes to the sense of place.

Generally throughout the United States, the government encouraged progress by, as Thomas Cox writes, "hacking farms from the forested wilderness and building a basis for a yeoman democracy in the process." The agrarian ethos

\footnotetext{
${ }^{1}$ See, Patricia Limerick, Legacy of Conquest: The Unbroken Past of the American West (New York: W.W. Norton \& Company, 1988).
} 
underlying this yeoman democracy became institutionalized almost immediately with the creation of the United States. In 1785 the Continental Congress formed a committee headed by Thomas Jefferson to perform a "rectangular survey." The survey divided land into six-square-mile townships, with 36 sections per square mile. Each section further divided into quarter sections of 160 acres, and thence into 40 -acre quarter-quarter sections. The numbering system made it possible to locate any 40 -acre tract on the public domain "with certainty and at once." According to historian Harold Pinkett, the rectangular survey established the policy of selling the public domain to settlers, making it a source of revenue as well as sovereignty. Thus, the newly formed U.S. government promoted and regulated public land acquisition. ${ }^{2}$

Consciously forming the distinctly American character undergirded public lands promotion. In American Virtues: Thomas Jefferson on the Character of a Free People, Jean Yarbrough writes, "a people that uses the power of the laws to enforce its conception of the good life will be very different from a people that relies principally on the family, religion, education, and other social institutions to form the character of its citizens." Thomas Jefferson, framer of the Declaration of Independence, defined the American right to "life, liberty, and the pursuit of happiness," according to a strong belief in the natural rights of man and a specific

\footnotetext{
${ }^{2}$ Thomas R. Cox, Changing Forests, Changing Needs: Using the Pacific Northwest's Westside Forests, Past and Present, eds. Dale G. Goble and Paul W Hirt (Seattle: University of Washington Press, 1999), 463; Gifford Pinchot, Breaking New Ground (New York: Harcourt, Brace and Company, 1947), 81; Harold T. Pinkett, Gifford Pinchot: Private and Public Forester (Chicago: University of Illinois Press, 1970), 16.
} 
political morality. This ideology, coined as "Jeffersonian democracy" connected closely with American public land laws. Promoting the small family farm would foster values of self-reliance, independence, industry, patience, moderation, and patriotism through a strong work ethic, holding private property, and agrarian virtue. $^{3} \quad$ Yarbrough groups Jefferson's reflections on work, property and character around three related issues:

... first, a decided preference for agriculture not merely as an occupation but as a morally superior way of life; second, a fear that a more fully developed commercial society will corrupt the American character by encouraging unwholesome occupations, consolidating and expanding political power, and promoting the rise of cities; and third, a defense of private property rights, and especially small-scale land ownership, as a means of fostering those virtues appropriate to a modern liberal republic. ${ }^{4}$

To Jefferson, cultivating the soil nourished the most significant virtues of a liberal republican society - industry, independence, and civic virtue. Assiduous farmers, freed from the vices of mercantilism, would invigorate the nation unleashing a "latent enterprising spirit" through hard work. They would enjoy the comforts of seasonal leisure while providing a comfortable subsistence. Democracy would develop from the independence of those who produced their own food without working for others. The farmer's natural spirit would fuel local political participation, and as his own master he would view fellow citizens equally. The "cultivators of the earth," claimed Jefferson, "are the most vigorous, the most independent, the most virtuous, and they are tied to their country and wedded to its

\footnotetext{
${ }^{3}$ Jean Yarbrough, American Virtues: Thomas Jefferson on the Character of a Free People (Lawrence: University of Kansas Press, 1998), xviii, xix.

${ }^{4}$ Yarbrough, American Virtues, 55.
} 
liberty by the most lasting bonds." Ideally, agrarian virtue would form the core of an American character upheld by public land policies and other forms of legislation that solidified the yeoman democracy. ${ }^{5}$

Following the rectangular survey, a century of public land policies facilitated American westward expansion and community development. These policies also defined the future of American forests. The forty-acre farms laid out by the rectangular survey succeeded in providing individual family farm subsistence in the humid east, but it did not work in the West. The growing American population demanded land, however transferring eastern systems to an arid and mountainous western landscape often failed. In most cases, it took more than forty acres to make a living in the West. To accommodate the demand for land, policies designed for expansion shifted west with the American people through the mid-to-latter part of the nineteenth century.

As settlers headed toward the newly created Oregon Territory in the 1840 s, a number of public land laws had opened the West to this Arcadian dream. Americans re-shaped the environment into bounded, prescribed sections through the legislated disposition of quantities of land, usually 160 acres, into private ownership. The first and most significant public land law, the Preemption Act of 1841 , allowed settlers to become established on a 160 -acre tract, and purchase it at $\$ 1.25$ per acre after survey. It also required that the settler "perform substantial acts as a bona fide actual settler theron," meaning he had to live on the land and file

\footnotetext{
${ }^{5}$ Yarbrough, American Virtues, 64-65; Thomas Jefferson to John Jay, August 23, 1785, quoted in Yarbrough, American Virtues, 65.
} 
a claim in the General Land Office. In Oregon, land laws differed. In 1843, the provisional government created a law that allowed any white male settler to claim a full section of land ( 640 acres) at no cost. This act brought approximately 10,000 people to Oregon between 1844 and 1849 , supporting a vision of agriculture that was a large part of the nation's vision of ideal western settlement. ${ }^{6}$

But, before giving public lands away, the American government had to obtain them. The U.S. and Great Britain joint occupancy established in 1818 ended with an 1846 treaty that created a division between the nations at the $49^{\text {th }}$ parallel. The treaty also recognized native title to land in the Pacific Northwest specifying that, "settlers are not to settle on or occupy land in use by the different Indians until such land is ceded to the United States by treaty." Prior to 1843 , when settlers legalized their land claims through the Oregon Provisional Government's Organic Code, anyone laid claim to a piece of land simply by settling on it. The Oregon Territorial Act of 1848, however, insured native rights "so long as such rights shall remain unextinguished by treaty between the United States and such Indians," thereby precluding any previous land grants. In the legal and proper sequence of events, Indians would relinquish land title to the U.S. government, thereby enlarging the nation's common holdings. Any area "acquired by treaty, capture, cession by States, conquest or purchase," became part of the undeveloped public

\footnotetext{
${ }^{6}$ Jan Prior, "Kinship, Environment and the Forest Service Homesteading in Oregon's Coast Range" (M.A. Thesis, Oregon State University, 1998), 27, 30-31; David A. Johnson, Founding the Far West: California, Oregon and Nevada, 1840-1890 (Berkeley and Los Angeles: University of California Press, 1992), 42; See also, Donald W. Meinig, The Great Columbia Plain: A Historical Geography, 1805-1910 (Seattle: University of Washington Press, 1968, 1995), 294-297.
} 
domain from which the government could redistribute lands and farmers could reshape, rename, and reconstitute the landscape and social structure. ${ }^{7}$

By the mid 1850s, U.S. expansion had reached the Pacific coast in full force, and legislated boundaries sped up the transformation of the newly mapped landscape. To encourage public lands settlement, between 1842 and 1856 Congress granted land outright in four territories, Florida, Oregon, New Mexico, and Washington. By 1849, the U.S. Army had established Vancouver Barracks along the Columbia River adjacent to the Hudson Bay Company's Fort Vancouver, extending U.S. dominance from Astoria, Oregon along the northwest coast as far as northern California. Within six years approximately $25,000-30,000$ immigrants entered Oregon Territory. In 1850, the Oregon Donation Land Claim Act (DLC) provided the means to bound land for settlement of Oregon Territory, including the Columbia's north shore. Under DLC a single settler could claim 320 acres, and couples as much as 640 acres. During the five years (1850-1855) of the legislation's existence, more than 7,000 claimants settled approximately 2.5 million acres. ${ }^{8}$ The law set the stage for establishing the Willamette Meridian and Base Line, a physical point near Portland, Oregon that serves as a reference point for all land surveyed west of the Cascades. The Willamette Base Line laid out the grid

\footnotetext{
${ }^{7}$ William G. Robbins, Landscapes of Promise: The Oregon Story 1800-1940 (Seattle: University of Washington Press, 1997), 82, 84; Michael Frome, Whose Woods These Are: The Story of the National Forests (New York: Doubleday \& Company, Inc., 1962), 37.

${ }^{8}$ Carlos Schwantes, The Pacific Northwest: An Interpretive History (Lincoln: University of Nebraska Press, 1989), 103; Johnson, Founding the Far West, 48.
} 
system of townships essential to providing legal descriptions to patent lands in the General Land Office.

The same year the DLC passed, Congress authorized treaty negotiations with the Indians of Oregon Territory, providing "for the Extinguishment of their claims to lands lying west of the Cascade Mountains." 9 The following year, 1851, Oregon Superintendent of Indian Affairs, Anson Dart, negotiated 19 different treaties with Lower Chinook Indians. None of these treaties were ever ratified. When Dart set out to negotiate with the tribes, he relied on his own observations, noting that few whites really knew the region very well, and that from the Cowlitz River to the Cascades there were "no real owners of the land living. It is occupied by the Vancouver Indians, of whom it will have to be purchased. Their band numbers in all sixty." ${ }^{10}$ Dart did not understand the complex relations that had developed between regional groups of native people, and between themselves and the fur traders, especially in relation to the cultural decimation that accompanied pestilence. Group affiliations relied on more than common language, although there were distinct linguistic differences between the Upper Chinook at the Cascades and the Lower Chinook Proper on the Coast.

Chinookan peoples had typically identified themselves based on place or other geographical constructions. Group names often confused Euro-American

\footnotetext{
${ }^{9}$ Congress, Senate, Committee on Indian Affairs, A Bill Authorizing the negotiation of treaties with the Indian tribes in the Territory of Oregon, for the extinguishment of their claims to lands lying west of the Cascade mountains and for other purposes, $31^{\text {st }}$ Congress, $1^{\text {st }}$ Session, S.B. 90.

10 "Letter from Anson Dart to the Bureau of Indian Affairs in 1851, reprinted in McChesney, et. al.," The Rolls of Certain Indian Tribes in Washington and Oregon (Fairfield, WA; YeGalleon Press, 1969).
} 
observers, making it difficult to provide an accurate census. In addition, many Indians, especially those known as Cascades, Shahala, or Watlala, from both sides of the river at the Cascades of the Columbia, had moved to Vancouver. The river provided no distinct divisions. The Wasco and Dog River Wasco of Hood River were closely related to the Cascades on the Washington side, and many from the mid-river region married upriver peoples and those from the Willamette Valley, such as the Clackamas. Having lost their socio-cultural foundation, the economic supremacy of the Cascade Indians at the portage had already declined, and Klickitat and Cowlitz people moved into the region near the Cascades of the Columbia, while land claims quickly dotted the banks. ${ }^{11}$ As he traveled between the coast and the Cascades, Dart noted approximately 120 Cascade Indians, 60 Vancouvers, 13 Tumwaters, 492 Klickitats, in addition to noting the small numbers of Clatsops, Tillamooks, Clackamas, and large numbers of Molallas (123), Kalapuyas (560), and Umpquas (243), among many others. The numbers and names of groups reported by Dart differ somewhat from those reported by later Indian agents and observers, although in some cases not significantly. ${ }^{12}$

As George Gibbs pointed out several years later, an "extraordinary diversity in the aboriginal tongues" existed west of the Cascades to the Pacific Ocean. The

\footnotetext{
${ }^{11}$ Beckham, This Place, 52-53.

${ }^{12}$ Anson Dart letter; United States Congress, Senate, United States Office of the Commissioner of Indian Affairs, "Report of A.P. Dennison, agent for the Indians of the northeastern district of Oregon," Report No. 94, August 1, 1858 in Report of the Commissioner of Indian Affairs, 1858, 265; United States Congress, Senate, United States Office of the Commissioner of Indian Affairs, R.H. "Report of R.H. Lansdale, agent for the Klickitat, Wisham, Columbia River, Yakima and Wenatch Indians," Report No. 188, August 1, 1859, in Report of the Commissioner of Indian Affairs (1859), 412.
} 
groups inhabiting that region, noted Gibbs, had far less connection with each other than those on the plains (except through trade), and far more connection with specific places. Gibbs remarked that the position of Chinookan peoples prior to their depopulation had been "most important," since they occupied the "great artery of Oregon," - the Columbia River - "principal thoroughfare between the interior and the ocean," for a distance of 200 miles. Their position had given them "unequaled" trade opportunity on the Pacific Coast. What Gibbs did not say, but what the Indians of the Pacific Northwest quickly determined, was that extensive efforts to co-opt those resources for United States citizens would be the immediate object of settlers and the government, reaching a crescendo of violence in the mid1850 s. ${ }^{13}$

Although a majority of Oregon settlers went to the Willamette Valley, free land and commercial potential also drew many to the Columbia's north shore where disease, legislation, and an onslaught of immigrants paved the way for long term white occupation. As historian Clifford Trafzer wrote, within five years of the 1849 California Gold Rush came a:

Flood of whites to the Far West. The white population of the Northwest expanded, and like spokes from a hub, they radiated in all directions in search of new lands and opportunities. . . In 1849 approximately three hundred whites lived north of the Columbia; a year later, over one thousand lived there. By 1853 , the year Washington became a territory, an estimated

\footnotetext{
${ }^{13}$ George Gibbs, M.D., "Tribes of Western Washington and Northwestern Oregon," Contributions to North American Ethnology Vol. 1, U.S. Geographical \& Geological Survey of the Rocky Mountain Region (Washington: Government Printing Office, 1877), 163. By the early 1880s, the "Indian question" was settled as the last cohesive groups in the Northwest were moved to reservations.
} 
four thousand whites inhabited Washington between the Columbia and Puget Sound. ${ }^{14}$

Within a few years of implementing the DLC, whites occupied land along the Columbia River from Cape Horn to Underwood. The first emigrants called the series of three rapids Upper, Middle, and Lower Cascades, or Landing. Their first construction was Fort Gilliam, known as "The Cabins," at the Upper Landing. These "rude log buildings" and a storehouse, the first lasting manifestations of Euro-American landscape change, had served as supply base during the Cayuse Indians Wars of 1846-1848. Between 1850 and 1853, this first series of long-term emigrants laid the basis for subsequent transportation systems, services to travelers, and townsites as they claimed the north side of the Columbia. The Shepard family established a DLC where the town of Stevenson now stands, and George W. Johnson had the site of the Lower Cascades surveyed for a townsite in July 1850 . He established a town, Cascades, and with George L. Johnson, Frances Chenoweth, and T.B. Pierce, opened a trading house. Two miles west of Stevenson, the town stood at the Lower Cascades and became known as the Lower Landing.

In 1851, Chenoweth and partner J.A. Bush built the Northwest's first tramway to carry goods around the Cascade Rapids. By 1852, three or four buildings stood at Cascades - the Chenoweth store, a bakery, a farmhouse, and a

\footnotetext{
${ }^{14}$ Clifford E. Trafzer and Richard D. Scheurman, Renegade Tribe: the Palouse Indians and the invasion of the inland Pacific Northwest (Pullman, WA: Washington State University Press, 1986), 31-32.
} 
building under construction. ${ }^{15}$ Charles Stevens described the developing communities along the river in 1853. At the Lower Cascades at the foot of the falls, about five miles below the Upper Landing stood:

... another town, or rather two towns, about half a mile apart, one has some half dozen houses or shops, the other one house, though a large one, and a $\log$ building, used for a store when we were there. This latter place, was the pleasantest of any in those parts, it being open, and level for about a half mile back, where it met the timber, and in a short distance back, the mountains. ${ }^{16}$

Like earlier explorers and traders, settlers flocking to the Willamette Valley in the 1840 s and 1850 s portaged at Cascades. There, during Oregon Trail days, settlers reassembled their wagons after rafting downstream from The Dalles. These Americans quickly recognized the value of the prolific fishery, the abundant forest resources, and the strategic potential for controlling river traffic at the rapids. Like the indigenous inhabitants, Chenoweth and his partners prospered through portage control. Two miles of slippery, muddy trails around the upper landing made portaging the rapids difficult. Chenoweth's two-and-a-half mile railroad, built of wooden trestles and ties laid on a graded roadbed with wooden rails, eased access to the Willamette Valley. A small flat car pulled by a mule carried goods around the rapids for 75 cents per one hundred pounds. People usually walked. From the middle to the lower landing, a wagon road provided the route. At times a bateau would land at the middle landing, then portage around the upper falls.

\footnotetext{
${ }^{15}$ Skamania County Pioneer, Historical Edition, 19 August 1955. The Historical Edition of the Pioneer reprinted excerpts of first person accounts as well as historical accounts regarding the county; Beckham, This Place, 83, 70.

${ }^{16}$ Stevens quoted in Beckham, This Place, 77.
} 
As American settlement developed along the river, some recognized the timber value in the forests to the north while others viewed forested lands as a farmer's challenge. The earliest settlers in the 1850 s raised stock in the rich Columbia River bottomlands, and some successfully grew apples, pears, cherries, strawberries, and other small fruits and nuts. Some cultivated wheat, oats, corn, potatoes, and onions. While growing wheat and fruit in the bottomlands of the Columbia fulfilled the Arcadian dream, the lands along the river gushed with capitalist promise. The forests, so much a part of the subsistence landscape for Cascades Indians, promised great profit to incoming whites, and nascent land policies upheld capitalist possibilities. Roger Attwell arrived at the Cascades in 1852, carrying 500 pounds of woodworking tools along the Oregon Trail. With a 320 -acre land grant at what is now Cascade Locks on the south shore of the Cascades, Attwell took advantage of the connection between forest and river - he immediately built a water-powered sawmill and boatways for building steamboats. By 1855, Felix G. Iman established a DLC and built a sawmill at Rock Creek near present day Stevenson, Washington. ${ }^{17}$

\footnotetext{
${ }^{17}$ Jim Attwell, Columbia River Gorge History, Volume One (Cascade Locks, Oregon: Tahlkie Books, copyright by Jim Attwell, 1974), 56-57, 62. Attwell prints first person recollections of members of Columbia Gorge communities; Elsie V. Bloomquist, Pioneer Historical Edition, 3, 8.
} 


\section{Takeover at the Cascades}

The 1850 s were signal years in the territories of Oregon and Washington. Gold discoveries in Washington Territory brought a surge of miners into native lands at the same time that thousands of migrants poured into the region. Most immigrants passed through the Columbia Gorge and many traversed the portage at the Cascades of the Columbia. The physical and perceptual struggle that ensued at the turn of the century on the Columbia's north shore reached a pinnacle in 1855 . Both Joel Palmer, the new Superintendent of Indian Affairs for Oregon, and the newly appointed governor of Washington Territory, Isaac Ingalls Stevens, worked assiduously that year to gain title to Northwest lands under the legislative stipulation that, if "practicable. . they shall remove all these small tribes... and leave the whole of the most desirable portion. . . open to white settlers." 18

As migrants poured into the territories, some native groups in Oregon and Washington began to agitate about the takeover of their lands. Two of the larger groups, the Yakama ${ }^{19}$ and the Cascades' closest neighbors, the Klickitat, had accurately predicted a land grab when the United States conducted a railroad survey through the Cascade Mountains in 1853. When the U.S. representatives sought to make treaties, many native leaders resisted. They knew what the whites wanted:

\footnotetext{
${ }^{18}$ Cox, Changing Forests, 160; Beckham. This Place, 92; Lane J. Bouman, "The Location of Oregon Donation Land Claims," (Professional Land Surveyors of Oregon Website, http://www.plso.org/readingroom/OregonDLC-Bouman.htm) [Accessed January 4, 2004], 2. ${ }^{19}$ The 1855 treaty is spelled Yakima, as is the town of Yakima in Washington State, however, the Yakama Nation has determined that they prefer the spelling "Yakama" to describe themselves and their ancestors, and that is the spelling I will use when referring to the Yakama Indians.
} 
land that they could fence and bound and call their own. Despite their qualms, some realized the necessity of meeting with American leaders. Others still, knew that in reality they had no choice but to try and get the best deal possible. As William Robbins points out, these groups were essentially forced to sign the treaties that conveyed title to most of what is known as Oregon today. Despite agitation by groups along the Umpqua and Rogue Rivers, "The end result was the forced removal of all native people..." from their homelands. ${ }^{20}$

In January 1855, Joel Palmer met those identified as Willamette Valley Indians at Dayton, Oregon. They included numerous bands of Kalapuya from the Willamette Valley, the Clackamas, relatives of the Cascades, the Willamette Tumwater (Tumwater meaning "Falls" in Chinook Jargon), and chiefs of the Watlala band of Tumwaters - Cascades from both sides of the river. Unlike the other treaties of 1855 , and there were many, Congress quickly ratified the resulting treaty, which ceded land from along the Columbia River below Oak Point to the Cascade Mountains and included the Willamette Valley where American communities were already established. Negotiations concluded January 22, and Congress ratified the treaty on March 3 . Congress accepted, ratified, and confirmed the treaty by April 10, 1855, and Indian agents chose a site 18 miles east of Lincoln City (Grande Ronde) for a reservation. The Cascades proved clever in their negotiations. They agreed to move to the chosen reservation, but with one

\footnotetext{
20 "Treaty with the Tribes of Middle Oregon" [CCRH Website, accessed January 4, 2004]; Robbins, Landscapes, 85; A. P. Dennison, United States Office of the Commissioner of Indian Affairs, "Report of A.P. Dennison, agent for the Indians of the northeastern district of Oregon," Report No. 94 (Washington: United States Office of the Commissioner of Indian Affairs, 1858), 262.
} 
stipulation. Article two of the treaty recognized the close relationship between bands on both sides of the Columbia. It provided that if any of the signatory bands had legitimate claim to land on the north side of the Columbia, they would remain able to participate in "any treaties hereafter entered into with the United States..." The Cascades were river Indians, not coastal, and they wanted the option to live on the river if at all possible. ${ }^{21}$

However, no such treaty ceding land on the north shore of the Columbia ever resulted from negotiations, during that year or thereafter. Nor did any of the reservations border the Columbia, except the temporary White Salmon Reservation that would be created the following year. ${ }^{22}$ Instead, treaty-makers grouped the Cascades Indians with others in ways that would later become problematic. A group of Wasco, and the Dog River Wasco, a large group from Hood River, Oregon, participated in treaty-making at Wasco near The Dalles, Oregon in June 1855. The outcome, the treaty with the "Tribes of Middle Oregon," ceded territory beginning in the middle of the Columbia River at Cascade Falls and running south along the summit of the Cascades to the $44^{\text {th }}$ parallel of north latitude; then east to the summit of the Blue Mountains; then north to a point due east from the headwaters of Willow Creek; west to the headwaters of the creek and back to the Columbia. This agreement also ceded the land in the Deschutes River watershed.

\footnotetext{
21 "Treaty between the United States and the Indians of the Willamette Valley" (10 Stats 1143) [University of Washington Libraries Digital Collection, American Indian Collection, http://content.lib.washington.edu/aipnw/index.html, Accessed January 5, 2004].

${ }^{22}$ Beckham, This Place, 44-45, 52-53; None of the extant treaties that I have been able to identify physically cede the land in this portion of Skamania County.
} 
The parties to this treaty were sent to the Warm Springs Reservation in 1858 after Congress ratified the treaty.

During the same period, Washington Territorial Governor and Superintendent of Indian Affairs Isaac Ingalls Stevens pushed for treaties with the Sahaptin groups of the Columbia Plateau and the Chinookan river Indians. Fluid boundaries along the Columbia River made for complicated treaty-making. In addition, the American impulse to legislate physical boundaries and gain access to westside lands, regardless of social boundaries, came into play during treaty negotiatons. In this case, the Yakama leader, Kamiakin, met with U.S. representatives and 5,000 members of other Indian nations at Walla Walla in June 1855. The groups listed in the treaty are:

Yakama, Palouse, Pisquouse, Wenatshapam, Klikatat, Klinquit, Kow-wassay-ee, Li-ay-was, Skin-pah, Wish-ham, Shyriks, Oche-chotes, Kah-miltpah, and Se-ap-cat, confederate tribes and bands of Indians, occupying lands lying in Washington Territory, who, for the purposes of this treaty, are to be considered as one nation. ${ }^{23}$

Stevens and his delegation appointed Kamiakin leader of the confederated tribes, and for the purpose of making a treaty gave him signatory authority for all of the groups, whether they agreed or not.

In this case, the ceded land began at Mt. Rainier and ran north along the main ridge of the Cascade Mountains to include the lands of Lake Chelan and the Methow Valley to separate the signatories of the Yakima Treaty from the Okanogans and the Spokanes who would have their own treaty. The Yakima

23 “The Yakima Treaty, June 9, 1855," Appendix 5 in Hunn, N'chi W'ana, 363. 
Treaty included the Palouse, and extended so far as to include the Nez Perce of southeast Washington, northeast Oregon and parts of Idaho. Although this treaty would also remove native people from their homelands, in some ways it focused on groups' connections to one another and to place more than the Palmer treaties had. It created three reservations, one near Yakima for the Yakama, Klickitat and other groups, another at Pendleton for the Cayuse, Umatilla, and Walla Wallas, and one at Fort Lapwai, Idaho for the Nez Perce. Still, the treaty did not recognize differences between river Indians like the Skin-pah and Wishram, Chinookan groups on the eastside who lived on the Columbia, and Sahaptin Plateau groups like the others. The treaty delegated most Washington Indians to the Yakama Reservation. The western dividing line for the ceded land rand down the Columbia to midway between the mouths of the Wind and White Salmon rivers, and thence along the divide of the rivers to the main ridge of the Cascade Mountains and back to the beginning. ${ }^{24}$

This treaty's boundary lay on the dividing line between east and west, ceding the land of the Klickitats to the United States government. The Klickitat's location at the time was already part of the changing system of boundaries resulting from American western migration. They claimed to have been pushed out of their homelands by the Cayuse, whom they despised. Like the Cascades and their upriver neighbors the Wishram, the Klickitat lived seasonally along the Columbia and its tributaries, the White Salmon, Klickitat, and Lewis to the northwest, and

\footnotetext{
24 “The Yakima Treaty, June 9, 1855," Appendix 5 in Hunn, N'chi W'ana, 363-364.
} 
inhabiting the valleys between Mt. St. Helens and Mt. Adams. In many ways, the Klickitat engaged in a seasonal round similar to their western neighbors along the rocky north shore, however, they were perhaps most adaptable of all. A Sahaptin people, and a mountain rather than a river people, the Klickitats rode horses and fished equally. During the summer, they could be found at Chequoss harvesting berries. Later they would meet the Yakamas for horse racing at Indian Racetrack, where the latter traded berries from the Cascades. They traveled extensively through the Cascades and into the lowlands, cutting a trail across the mountains that provided a main overland thoroughfare in all directions. ${ }^{25}$

Like others who had endured the rampant pestilence that intermittently swept the coast and plateau, the Klickitat had found ways to survive. In 1853, George Gibbs described how the Klickitat had adapted to 30 years of exposure to white culture:

Very few characteristic features remain among these people. Their long intercourse with the Hudson's Bay Company and of late years with the Americans, has obliterated what peculiarities they may have had, nor is there any essential difference in their habits or manners from those Indians adjoining them. They use for the most part the arms and utensils of the whites, and the gun had superseded the bow and arrow. The pails and blankets constructed from the bark of cedars, the saddles, and fishing apparatus are their principle articles of domestic manufacture and of such things it is almost as common to find the imported substitutes. ${ }^{26}$

It was survival that drove Kamiakin to sign the Yakima Treaty. He had been warned that the land would be taken by force if he did not sign. But the Yakama

\footnotetext{
${ }^{25}$ George Gibbs quoted in Selma Neils, The Klickitat Indians (Portland, OR: Binford \& Mort, 1985), 73; Maggie McLaughlin in Townsend, Skamania, 22.

${ }^{26}$ Gibbs quoted in Neils, Klickitats, 73.
} 
leader quickly reneged, as it became apparent that despite his promise, Governor Stevens could not keep whites out of the region. When Kamiakin decided to leave the Walla Walla Council, Stevens threatened him with violence. Before leaving Walla Walla, Stevens sent dispatches to coastal newspapers announcing the opening of the Inland Northwest east of the Cascades. Even more white miners entered the region, and a series of conflicts ensued when some miners stole horses and raped Indian women on Yakama lands. Native retaliation resulted in the death of three miners in the summer of 1855 , and what Clifford Trafzer has deemed "a watershed in Pacific Northwest history," the murder of Yakama Indian agent Andrew Bolon. The Indian agent's death heralded the Yakama Indian Wars, which lasted from 1855 to 1858 . During that time, a loose confederation of groups, including the Yakamas, Wenatchees, Walla Wallas, Umatillas, Cayuses, and others fought side by side against the U.S. Army and territorial volunteer forces. The Klickitats and Cascades too, eventually became become part of conflict.

In 1855 , fear ran high in settlements west of the Cascades and in the Willamette Valley, as rumors circulated that a united Indian force would kill all whites in the region. After a series of skirmishes between volunteer troops, the army, and native peoples, in March 1856, Colonel George Wright, commander of Fort Vancouver Barracks, prepared to march troops upriver to The Dalles to begin the Yakima campaign of $1856 .{ }^{27}$ Colonel Wright's plan to gather forces at Fort

\footnotetext{
${ }^{27}$ Trafzer and Scheurman, Renegade Tribe, 61-62,67, 71; Clifford E. Trafzer, ed., Indians, Superintendents, And Councils: Northwestern Indian Policy, 1850-1855 (Lanham, MD: University
} 
Dalles for the march east hinged on availability of certain strategic locations in the Columbia River Gorge. Fort Dalles, established in 1850, provided a base of military operations to quell native peoples on the Columbia Plateau. And the Cascade landings, 38 miles downriver from The Dalles, became the link between Fort Vancouver Barracks and Fort Dalles. By 1855, the transit site at the Cascades had already been reconstructed and redefined on American terms.

Federal involvement at the Cascades increased in 1855 when the army built Fort Rains or the Middle Blockhouse in October, eventually one of three military stations at the rapids. The site's strategic importance had become evident and soldiers moved into the area to build a military portage road along the north shore. Like other blockhouses constructed around the region during the 1855 Indian Wars, its purpose was to protect settlers. Perhaps more significantly, Fort Rains served as a supply base between the east and west sides of the Cascades. George Griswold transported the freight around the portage from the Upper Landing to the Middle Landing, and thence on the wagon road from the Middle Landing to the Lower Landing. During the same year, the army built Fort Cascades on the Johnson farm at the Lower Landing, where the town of North Bonneville now stands. Fort Cascades became the headquarters and site of military operations at the Cascades between 1855 and 1861 . The army later constructed its third blockhouse, Fort Lugenbeel, at the Upper Landing overlooking the head of the portage at the same location volunteer soldiers had established Fort Gilliam or "The Cabins" in 1847.

Press of America, 1986), 4. See Trafzer, Indians, Superintendents And Councils to understand the complexity of the Yakima Indian Wars and treaty making in the Pacific Northwest. 
The struggle for control of the Columbia River Gorge is significant to sense of place in the region. The Fort Cascades National Historic site stands one mile west of Bonneville Dam. Visitors can reach the site from the Washington side of the Columbia by traveling along Highway 14 , and from the Oregon side by crossing the Bridge of the Gods from Cascade Locks. Near Bonneville Dam, visitors can hike on the 1.5-mile Fort Cascades trail, carrying a brochure to guide them though a series of historical sites. At Fort Cascades, visitors will encounter a tale of conflict, settlement, and takeover by the U.S. government in the $1850 \mathrm{~s}$. For Indians, no protection from white encroachment existed on the Columbia's north shore. The U.S. Army provided a defense for white emigrants. The pull of the river's commercial potential drew white settlers to its shores where they created a Euro-American built environment, with new businesses, homes and farms as visible signs of the cultural phenomena overtaking the gorge. By the fall of 1855 , a wharf boat at the Johnson farm at the Lower Landing received freight and passengers. At the Middle Landing a hotel run by the McNatt family housed Oregon emigrants passing through to the Willamette Valley. At the Upper Landing, just above the first series of rapids, the Bradford Store catered to nearby settlers and to travelers.

In the spring of 1856 , as tensions rose on the east side of the mountains, a group of Indians attacked and besieged the white settlements at the Cascades. Three weeks earlier, Indians had burned down the Joslyn house, twenty-two miles east of what would become Stevenson, the first homestead on the east side of the 
White Salmon River. ${ }^{28}$ Luckily for Erastus and Mary Joslyn, a friendly Indian woman warned them of an impending attack and they escaped to The Dalles. Residents along the Columbia at Hood River and The Dalles had generally been on the lookout for trouble, but were fairly confident in their good relationships with the Cascades Indians. On the morning of March 26, Indians attacked the three landings simultaneously. At the Lower Landing, some settlers received wounds, but escaped by boat, while the Indians burned everything around them. At the Middle Blockhouse, Christiana Griswold, nearly 13 years old at the time, recalled hearing shots and assuming soldiers had fired their guns at the Middle Blockhouse. She walked out into the yard, only to have six shots go over and around her, "the last one striking a little boy by my side. He cried out, 'I am shot!' Then we seemed to understand that we were in danger and went in the blockhouse." People flew in the door of the blockhouse, and one of the seven soldiers stationed there lay dead on the hill. The German boy, shot next to Christiana, lay in sight of the fort, in death throes until nightfall. George Griswold, the government transporter and Christiana's father, died in the blockhouse of a gunshot wound as she held his head in her lap. ${ }^{29}$

Two weeks later, Lawrence Coe of the Cascades, who worked for Putnam Bradford, described the "tea party" at the Upper Landing:

\footnotetext{
${ }^{28}$ Located where the town of Bingen stands today.

${ }^{29}$ Beckham, This Place, iii-iv, 123, 126, 77-79; Mary Joslyn, reprinted in Atwell, Columbia Gorge, 88; Christiana Griswold reprinted in Atwell, Columbia Gorge, 121-122; Stephen Dow Beckham provides an account of the military occupation of Fort Cascades in This Place is Romantic and Wild, 107-122.
} 
On Wednesday, March 26, about 8:30 A.M. after the men had gone to their usual work on the bridges of the new railway. . . the Yakimas came down on us. . . Of our men, at the first fire, one was killed and several wounded. . . Our men, on seeing the Indians, all ran for our store through a shower of bullets. . . Bush and his family also ran into our store, leaving his own house vacant. $^{30}$

Others arrived at the Bradford Store, including the Watkins family and some men working to build a new warehouse and new bridges on the portage railroad line. Some had been shot in their homes, others were shot amidst the initial confusion. Mr. Watkins, who was shot in the wrist, with the ball exiting at his elbow, could not reach the store and so lay for two days and two nights upon the hill, fainting and rolling into the icy river, then crawling back up the hill as his wife and children watched him from the store window. By late in the day, approximately 40 men, women and children took refuge in the Bradford Store. During the first day, the hostages watched as the Yakamas, Klickitats, and some Palouses burned the Iman's two houses, Putnam Bradford's sawmill, and the lumber yard at the mouth of Mill Creek. The following morning at daylight, they set fire to the new warehouse on Bradford Island. $^{31}$

The Indians killed one woman and eleven men, but with military assistance the white migrants prevailed. As Coe recalled, nine U.S. government rifles with cartridge boxes and ammunition were available behind the counter at the Bradford Store. The rifles, intended for transport downriver saved the settlers at the Upper

\footnotetext{
${ }^{30}$ Coe reprinted in Atwell, Columbia Gorge, 92.

${ }^{31}$ Beckham, This Place, 85, 124; Coe reprinted in Atwell, Columbia Gorge, 93-94; Trafzer and Scheurman, Renegade Tribe, 71.
} 
Landing. During the outbreak, the steamboat Mary, moored at the Lower Landing, escaped, and the passengers warned soldiers downriver. Lieutenant Philip Sheridan, later a Civil War hero, left Vancouver with a detachment of troops, arriving at the same time that Lieutenant-Colonel Edward J. Steptoe came downriver. Together they and their troops successfully freed the settlers after a bloody, three-day struggle. ${ }^{32}$

On the first day of the conflict, settler George Johnson had advised local Indians to go to Bradford Island, where Sheridan reported he found the entire body of Cascades, men, women and children. Sheridan claimed that the chief headmen put all the blame on the Yakamas and their allies, saying they had not participated. The lieutenant did not believe them, and so performed a gun test. He lined up the men, asked them if they had taken part in the attacks, and when they denied it, placed his finger in the muzzle of each man's gun: "My finger was black with the stains of burnt powder; and, holding it up to the Indians, he had nothing more to say in the face of such positive evidence of his guilt. A further examination proved that all the guns were in the same condition." The future Civil War hero arrested 13 of those he considered "principle miscreants" and sent them under guard to the Lower Landing. The following day, Sheridan turned the prisoners over to Colonel George Wright, who marched them to the Upper Landing, "where, after a trial by a military commission, nine of them were duly hanged." 33

\footnotetext{
${ }^{32}$ Philip Sheridan, Personal Memoirs of P.H. Sheridan, Vol. 1 (New York: Charles L. Webster \& Company, 1888), 80.

${ }^{33}$ Sheridan, Personal Memoirs, 83.
} 
Lawrence Coe, who acted as interpreter for the Indians, described the scene in his letter to Putnam Bradford. Chenoweth, the first to go, "died game," although he tried to bargain for his life, offering 10 horses, two squaws, and something for every "tyee." Chenoweth's main concern was that he would not be buried properly in an Indian dead house, but rather would be put in the ground. The impromptu hanging took place under a tree with two barrels, a not so efficient manner of execution. When the rope failed, the soldiers shot Chenoweth. Coe declared he was "glad to see the old devil killed, being satisfied that he was at the bottom of all the trouble." Ironically, Mum-shum-sie, Chenoweth's wife, had warned the Atwells about the attack of the Yakamas, at Chenoweth's behest. The following day the soldiers hanged Tecomeoc and "Captain Joe," who Coe says told him that all the Cascades were in the fight. The following day's executions included Tsy, Sim Sasselas and "Four fingered Johnny." Next came Chenoweth Jim, Tumulth and Old Skein. The Indians, "being under treaty," had been convicted of treason. Obanahah, who had signed the Grande Ronde treaty, was sent to Vancouver, placed in ball and chain, and eventually released. ${ }^{34}$

Tumulth descendant Chuck Williams also claims they had been signatories, and that is why the executions were unjustified:

\footnotetext{
${ }^{34}$ Phil Sheridan reprinted in Atwell, Columbia Gorge, 118; Phil Sheridan reprinted in Pioneer, Historical Edition; Sheridan, Personal Memoirs, 70-84; Coe in Atwell, 98-99; Mary Atwell in Atwell, Columbia Gorge, 86. It is unclear which of the executed actually were treaty signatories since Indian names are used on the treaties and are not exactly the same, but are similar in some cases to those executed. Grande Ronde Treaty signatories included Anta, Quilalla, or John (perhaps Four-fingered Johnny?), Mequah, or Dick, Yackatee, or Sam, Tophor, or Jim Brown (perhaps Jim?), Pulktah, Tumulth, Obanahah, Watchano, Teapinick, Wallahpicate. Chewotnleth (perhaps Chenoweth?) is listed on the Middle Oregon Treaty, as are two more Jims, and Mission John. None of the other Wasco or Dog River Wasco fit the given names in the historic literature.
} 
The Cascades didn't flee, because they had just signed the treaty, so they figured they were kind of exempt from it, and he [Captain Sheridan] needed a scapegoat so he hung nine of the leaders, including my great-grandpa who was the head chief [Tumulth]. The trial consisted of Sheridan putting his fingers in my great-great-grandpa's gun that had been recently fired, so he hung him on the spot." 35

Perhaps some Cascades did participate in the attack, but based on the warnings provided by friendly Indians, including Mum-shum-sie, the eyewitness accounts that Klickitats and Yakamas were responsible, and the simple reality that settlers would have recognized local Indians, it is not likely they were the main perpetrators. Some possibly left Bradford Island and interacted with the attackers, as noted by Lawrence Coe. Sheridan reported that Indians were racing horses and enjoying themselves at the Lower Landing when he secretly passed by on his way to the rescue. ${ }^{36}$ It is just as likely that Williams is correct, that the rapid and vicious hangings at the Upper Landing were meant as a lesson not only to the Cascades, but to any other Indians who dared to revolt from the American takeover of the Pacific Northwest.

The violence begun at the end of March continued, turning again to the Indian community. A few days after the rescue, Sheridan found the bodies of a missing Indian family, the Spencers, in between the upper and lower landings. The bodies had been placed in an open space about a mile from the road. The mother,

\footnotetext{
${ }^{35}$ Chuck Williams, "An Interview with Chuck Williams," interview by Kathy Tucker 26 April 2000, interview 2773.1, transcript, Columbia Communities Oral History Collection, Oregon Historical Society, Portland, Oregon, 2.

${ }^{36}$ Sheridan, Personal Memoirs, 78.
} 
two boys, three girls, and a baby had all been strangled and left in a semi-circle in the woods:

the bits of rope with which the poor wretches had been strangled to death were still around their necks. Each piece of rope, the unwound strand of a heavier piece, was about two feet long and encircled the neck of its victim with a single knot, that must have been drawn tight by the murderers pulling at the ends. As there had not been quite enough rope to answer for all, the babe was strangled by means of a red silk handkerchief, taken, doubtless, from the neck of its mother. ${ }^{37}$

Sheridan knew that an angry white person from the Middle Blockhouse had been the perpetrator, but no one ordered an investigation. These events at the Cascades cemented the American hold on the Columbia's north shore. Soldiers from Vancouver took many of the Cascade and Klickitat Indians downriver where they were held while arrangements were made for removal to a reservation. The Indians remained at Vancouver that spring and summer, closely confined and prevented from their usual hunting, gathering, and salmon fishing activities. Meanwhile, thieves stole their horses and destroyed their property, leaving little behind.

As the winter of 1856 approached, Indian agents rounded up those held at Vancouver and moved them to the newly-created White Salmon Reserve. Indians at the Reserve included other Vancouver and Lewis River Klickitats, some Klickitats and Yakamas who had participated in the Indian wars, a few Indians from Fort Simcoe, and about 340 friendly Cascades, or about 800 Indians in all. The White Salmon Reserve extended for fifteen miles on the Columbia between the

\footnotetext{
${ }^{37}$ Sheridan Personal Memoirs, 88.
} 
Klickitat and White Salmon rivers. The boundaries extended north another twenty miles to LaCamas Prairie on the east slope of the Cascade Mountains, where Indians from Vancouver to the Spokane River gathered annually to collect Camas.

A. Townsend, the White Salmon's first Indian agent described the reserve in an

\section{7 report:}

The country is well adapted for Indian use - containing within itself an abundance of wild roots, berries, game, and salmon - while it is very poorly adapted for agricultural purposes; is very mountainous; while a short distance back from the Columbia river, owing to elevation, frosty nights prevail most of the summer. There is a small amount of tillable land on the Columbia, where the agency building is erected, and at the mouth of the Klickitat river where a band of the Indians are living; here fair crops can be raised, though the dry climate renders irrigation necessary. ${ }^{38}$

Agent Townsend built a house for storage four miles above the mouth of the White Salmon River, on the same land claimed by Erastus Joslyn, whose property the Indians had destroyed. The Joslyns remained first in The Dalles, and then in Forest Grove, Oregon, after the attack on the Cascades. When they returned in September 1856 , they found their land had been taken over by the government, their cattle gone, the buildings burned, fruit trees pulled out, and quantities of timber cut for new buildings and as cordwood. A blockhouse and new barns stood on the property, which now housed soldiers, Indians, and Indian agents rather than settlers. The Joslyns' property would not be returned to them for nearly three

\footnotetext{
${ }^{38}$ United States Congress, Senate, United States Office of the Commissioner of Indian Affairs, "Report of A. Townsend, local Agent at the White Salmon reservation," Report No. 143, June 30, 1857 in Report of the Commissioner of Indian Affairs (1857), 348.
} 
years, and it would take sixty years before the family received compensation from the government for rent and damages. ${ }^{39}$

Meanwhile, at the farm turned reservation, the winter of 1857 approached. Agent Townsend requested supplies to help them through the winter, although no treaties had yet been ratified and thus no funds had been allocated, and the reserve held many non-treaty Indians. In the spring, however, Townsend deliberately curtailed supplies in an effort to "instill industry" among the Indians. Many "took to the mountains and valleys back, in search of roots and game," but some decided to try farming. Approximately 100 heads of families asked for and received tools, seed, and as much plowing assistance as possible. They planted about 30 to 40 acres of potatoes and peas. The peas withered, but Townsend expected a "fair crop" of potatoes. ${ }^{40}$

During the summer of 1858, Agent Dennison, in charge of the northeastern district of Oregon and a small portion of Washington Territory, including the White Salmon Reserve, urged ratification of the Middle Oregon treaty. He reported that there were now about 1,200 Indians on the White Salmon Reserve, including the Dog River (130) and the Wascoes (450). Dennison claimed the Indians had made rapid improvements in agriculture, but were "discouraged and disheartened." Although Dennison did not say so, it is clear that the Indians quickly learned that agriculture would not be more dependable than their traditional ways - harvesting roots, berries, game and fish from the mountains and rivers of the Cascades. Frost

\footnotetext{
${ }^{39}$ Neils, The Klickitas, 95-96.

${ }^{40}$ Neils, The Klickitats, 348-349.
} 
had destroyed about half of their corn and beans, and the unseasonably cold season left them with only half an average crop. R.H. Lansdale, the new White Salmon agent, decided a pastoral rather than an agricultural life suited these Indians best and decided to spend the remaining annual funds on cattle. In an effort to shape the character of the Indians for a refined future, Lansdale planned to distribute the cattle wisely. Only the most friendly natives would receive the bovines:

This distribution, as well as that of agricultural tools and seeds, is intended not only to foster and strengthen their friendship, but also to domesticate the Indians and to fix them to the soil, as such domestication must always underlie any permanent progress in civilization. ${ }^{41}$

Eventually, the Indians would surely become part of the moral fiber of the American character, through their agricultural endeavors.

Meanwhile, somehow the Indians on the reservation had to survive while they awaited ratification of treaties and the fulfillment of government promises for land, education, tools, and health care. Significantly, those who signed the Yakima Treaty retained the right to hunt, fish, and gather at their usual and accustomed sites. However, even the salmon harvest had become problematic due to the reserve's far distance from the fisheries at the Cascades and other traditional sites along the Columbia. ${ }^{42}$ Rocky terrain prevented access by wagon to the main fisheries, now between thirty-five and seventy-five miles away. The Indians harvested less salmon than usual that year, having to leave large quantities of fish

\footnotetext{
${ }^{41}$ United States Congress, Senate, United States Office of the Commissioner of Indian Affairs, "Report of R.H. Lansdale, agent for the Indians north of the Columbia River and east of the Cascade Mountains," Report No. 99, August 1, 1858 in Report of the Commissioner of Indian Affairs (1858), 275.

${ }^{42}$ Major fishing sites were located at the Cascades and at Celilo Falls near present-day The Dalles.
} 
for extended periods because it had to be packed to the distant reservation. In addition, they contended with theft and vandalism by "vicious white persons and Indians." Agent Dennison encouraged them to salt the salmon, a "profitable" endeavor. He also requested $\$ 3,000$ to erect houses for drying the fish. ${ }^{43}$

Dennison reminded his superiors that these tribes were not sympathetic to the hostile Indians who continued to wage war. Those on the White Salmon Reserve had "continued friendly toward our people." By the following year, the treaty had been ratified and became "a supreme law of the land," according to Agent Dennison. He then noted the great reluctance of the Indians to move from their old hunting, grazing and camping grounds: "They are aware of the evils connected with gathering large bands of Indians upon a reservation.” Still, the Indians at White Salmon moved to Fort Simcoe, and the Yakama Reservation was identified as the permanent Indian agency. There, Dennison declared they were "as thoroughly subdued and subjected to the rule of the white man: so emphatically is this the case, that nothing demanded of them as proof of their friendship for the whites is too hard to perform." In 1859, Agent Lansdale, in charge of the Klickitat, Wishram, Columbia River, Yakima, and Wenatchees, took a census of the Indians who had moved to Fort Simcoe. They included Sahaptins - 633 Klickitat, 667 Yakama, 50 Wenatchee; and Chinookan - 471 Wishram and 808 Columbia River, many of whom were likely from mixed bands. However, Lansdale also noted that he could not count many bands of Columbia River Indians, "who are to be removed

${ }^{43}$ Dennison, Report No. 94, 263. 
to this reservation." These Columbia River Indians were included in the Yakima Treaty, the ratification of which he previously opposed because so many of the Indians did not want it. However, Dennison realized the treaty was likely as favorable as possible and turned instead to asking the government to quickly fulfill its financial promises, "after years having elapsed since the contract was made." Military dispersion and removal to reservations left the region open for nonIndian settlement. The broad processes of cultural and ecological change that began during the first years of American settlement continued, picking up speed as native people moved to reservations. A number of Cascades did remain on the north shore, accommodating to the changed social landscape. Many of them married whites as the claims dotting the north side of the river rapidly reshaped the land and culture into a bounded, Americanized form.

During the first years of settlement, Americans viewed the gorge as an obstacle. Then the military recognized the strategic significance of the transportation stronghold at the Cascades and built Fort Cascades and the Military Portage Road. The planked road used an estimated 23,760 feet of wood planking. A bridge over Hamilton Creek, now Greenleaf Slough, used so much wood that the sawmill at the Upper Landing could not provide enough lumber for the project. It required military engineers to come to the area to fell trees, haul logs from the forest, and cut the dimensional lumber for the bridge. ${ }^{45}$ These major engineering feats - the military portage road and the bridge - played important roles in opening

\footnotetext{
${ }^{44}$ Lansdale, Report No. 188, 412-413.

${ }^{45}$ Beckham, This Place, iii-iv, 95.
} 
the region to further settlement and facilitating a new relationship between river, forest, and human communities.

\section{"We have got to work": logging, lumbering and building community}

Although settlers came into a managed landscape, a qualitative difference existed between native land alteration through fire and the ecological reshaping caused by joining a market ethos with Euro-American technologies. The Indians of the Cascades traded goods and accumulated wealth for annual subsistence needs and artistic expression, rather than for a capitalist accumulation of wealth. Native trade practices and seasonal harvest and residential patterns resulted in relatively low impact environmental change. The settled Euro-American residential and trade patterns resulted in more permanent and deeper changes to the landscape, imposing a new shape and form on the environment. In the Willamette Valley, the relationship between agriculture and distant markets rapidly recreated the landscape. On the Columbia's north shore, the relationship between forest and river, underscored by an American capitalist ethos, shaped a very different landscape than before. Whereas the Willamette Valley imposed, as historian William Robbins puts it, "the form and function of the built environments left behind in the Midwest," form deviated in the Columbia Gorge. ${ }^{46}$

In the Gorge, no matter what, the landscape prevailed. The physical environment of the gorge, rocky and timbered, precluded field agriculture, and

\footnotetext{
${ }^{46}$ Robbins, Landscape, $82,91$.
} 
geographical change occurred as settlers and the military placed buildings, roads, railroads, and towns along the north shore. Cutover lands left stumps, but the stony hills and valleys of the gorge determined building placement, precluding some areas and leaving only pockets for a built environment. The mountainous landscape itself prohibited the neat, straight tree-lined roads of the Midwest. The dominance of evergreens, and the heavy green vegetation spread over rocky basalt continued to "throw" what George Gibbs deemed "an aspect of gloom over the landscape.,47

Communities developed on the north shore in a somewhat unfavorable agrarian environment. The idea of farming had a strong hold there as elsewhere, but the landscape required north shore emigrants to facilitate their livelihood otherwise. Instead, settlers made extensive use of forest and river by developing transportation systems at the Cascades, the most significant factor in north shore community development. Settlers used wood from the forests to build the allimportant steamboats that moved goods upriver to The Dalles. Wood choppers cut cordwood for the steamers that carried goods and passengers between The Dalles and Portland. Wood also provided the trestles for the portage railroad that made the Cascades and Stevenson the most significant transportation sites on the midColumbia River. ${ }^{48}$ Wood provided material for home and business construction, and like the previous inhabitants settlers harvested berries, hunted, and fished in the Columbia's tributaries. Growing crops like potatoes complemented natural

\footnotetext{
${ }^{47}$ George Gibbs, "Tribes of Western Washington and Northwestern Oregon" in Contributions to North American Ethnology. Vol. 1. U.S. Geographical \& Geological Survey of the Rocky Mountain Region (Washington: Government Printing Office, 1877), 165.

${ }^{48}$ Beckham, This Place, 136-138.
} 
subsistence patterns. "For food," said one settler, "we had salmon, spuds and plenty of wild game." Although subsistence use of forest and river played an important role in occupying the Columbia's north shore, commercial operations prevailed. A significant relationship existed between the timbered landscape and settlers' drive for success on the river. This connection is evident in the letter from Lawrence Coe to Putnam Bradford. After describing the 1856 attack, Coe declared: "We have got to work again building and transporting; are going to build a sawmill as soon as we can."${ }^{, 49}$

Some who came to the Columbia's north shore in the 1850 s sought farms, but it was the market potential of the Cascades region's dense westside coniferous forests that drew others. Tree removal from streamside corridors and the lands along the Columbia began immediately as farmers cleared land and the lumbering industry got underway. Like most western logging and lumbering sites, technological and transportation developments influenced advances. Without railroads, only navigable streams or major water bodies provided the means to access markets. The Columbia and its tributaries provided ideal access to both timber and markets. The general rule in western lumbering was "small mills in abundance, stationed close to the timber, and sometimes almost as numerous as

\footnotetext{
${ }^{49}$ L.W. Coe letter to H.C. Coe, in the Oregonian, 4 April 1856, reprinted in Skamania County Pioneer, Historical Edition. 19.
} 
family farms," with the number of sawmills rising in good times, and dropping according to the economy. ${ }^{50}$

As in most western communities, early Skamania County timber ventures began with simple sawmills built to mill timber for home and barn construction. Box houses of lumber sprung up along the river, decorated inside with wooden boxes and benches for furniture. Migrants immediately recognized opportunities to market the resources of the gorge and benefit from the natural barrier at the Cascades. Felix Iman, a carpenter, went to the Cascades in 1852, because, said his son Louis, "there was more opportunity here for work and better pay." In the Midwest Iman made only eight dollars a month, but one day of building boats and boathouses at the Cascades yielded the same amount. Iman built two sawmills on his DLC along Rock Creek, west of present-day Stevenson.

\footnotetext{
${ }^{50}$ Michael Thoele, Bohemia: The Lives and Times of an Oregon Timber Venture (Portland: Oregon Historical Society Press, 1998), 23.
} 


\section{his DLC along Rock Creek, west of present-day Stevenson.}

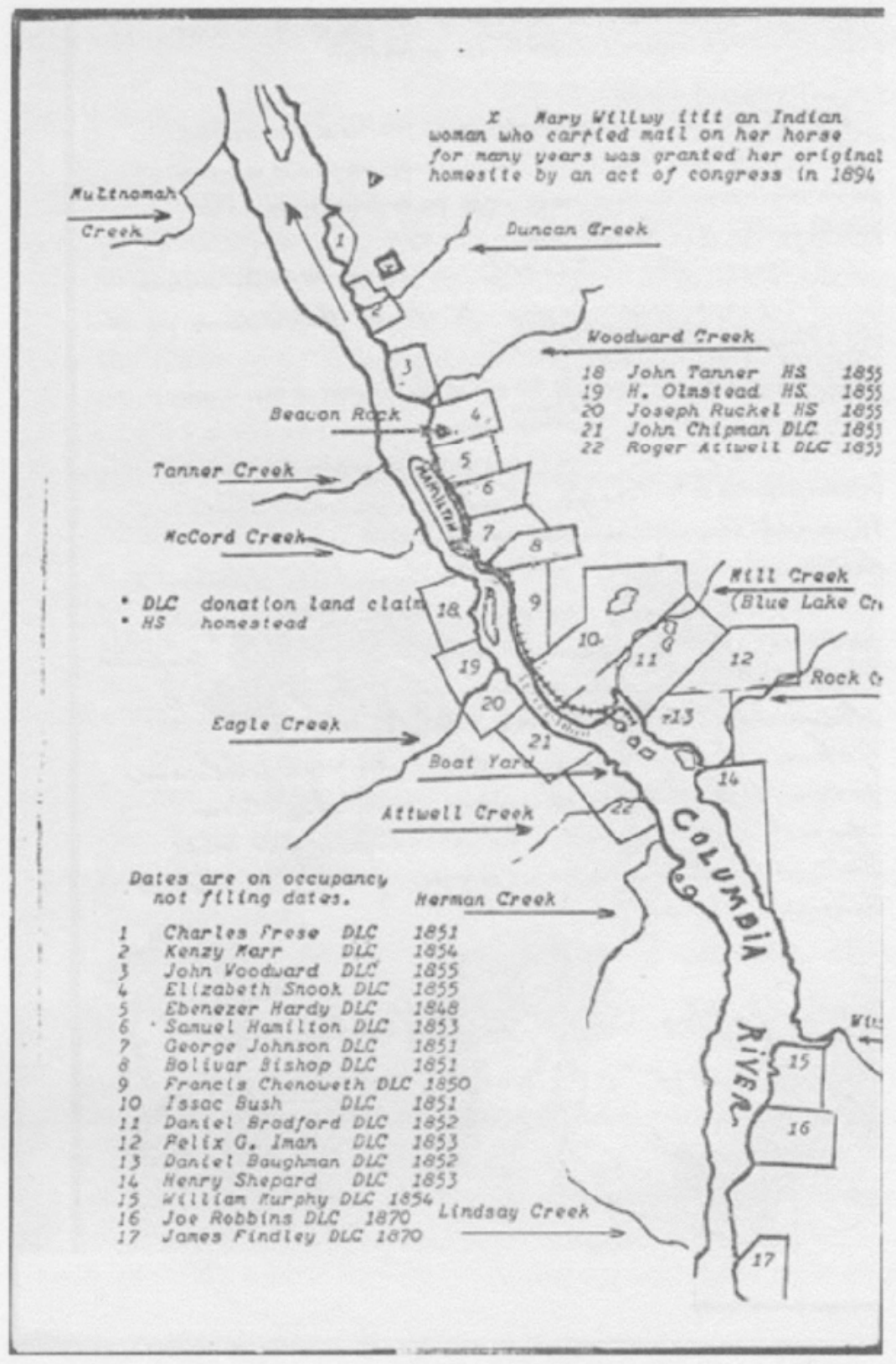

Figure 5: Map of North Bank Columbia River Land Claims 
The first was a sash saw mill, the next a water-powered mill, built by damming Rock Creek and creating a 60 foot overshot water wheel. ${ }^{51}$ Michael Thoele describes the development of the sash saw:

... a direct descendant of the medieval pit saw, an abominable, handpowered creation in which a log mounted on an elevated frame required one man atop it to work the upper end of a long saw blade and another man beneath, in the cascading saw-dust. Up and down, up and down they worked the blade, like toy figures in some mechanical clock producing a few planks each day. ..."52

The water-powered sash-saw could out-produce the medieval pit saw by twenty to one.

As in the case of the Iman Mill, water wheels converted rotary power to a reciprocating motion to power a blade through the log. Rock Creek would have been dammed to create a small pond, "then... a flume trough would have been built to carry a fast, narrow stream to a water wheel. Falling water would spin the wheel, and a gear or drive-belt assembly would transfer power to the machinery of the mill." A crank-shaft converted the wheel's rotary motion to reciprocating motion. The name "sash-saw" came from the rocker arm attached to a frame, or sash, which held a vertical sawblade. There would have been guides and a spring system, possibly a bent sapling, to return the sash after each cutting. The saw had a wobbling blade that took a "kerf," meaning it cut more than $1 / 2$ " wide on every

\footnotetext{
${ }^{51}$ Thoele, Bohemia, 23; George Iman, "Early Days at the Cascades"; "Iman Mill" personal interview by Hulda Howell, in Dorothy Sams, History of Skamania County (Stevenson, WA: History Committee, Skamania County Community Development Program, 1958), 20; Iman, Louis F. in James Harris, "Skamania County." Told By the Pioneers, U.S. Works Progress Administration. Vol. 3, Washington Pioneer Project (Printed under WPA Sponsored Federal Project No. 5841, 1938), 68-70.

${ }^{52}$ Thoele, Bohemia, 19.
} 
downstroke. The kerf resulted in a half plank lost for every one-inch plank cut. After 1853, the circular saw replaced the sash saw, revolutionizing sawmilling. The position of the blades, one above the other, made it possible to cut very large logs. A five-and-a-half foot circular saw could cut a log equal to half the diameter, and the size could be doubled by placing two saws, "gang saw blades," one above the other. With circular saws, mills cut up to 5,000 board feet of lumber in a twelve-hour day. However, only sash saws existed at the Cascades in the 1850 s. $^{53}$ Across the river from Felix Iman, where Roger Atwell took his claim at Cascade Locks "because of the fine timber on it," a skid road to transport saw logs by oxen led to a mill. During this era, loggers went out into the woods and felled the giant trees by hand with single-billed saws. Once felled, the men cut the huge trees to a manageable length, sniping or beveling a log's end so it would slide easily. "A chain would be thrown on the log, the skids would be greased, the bullwhacker would roar and swear and crack his whip, and four to twenty oxen would strain against their yokes to drag the monster from the woods." Skid roads often extended as far as two miles into the forest, with streams and rivers used to float giant log rafts to the mills. Splash dams blocked rivers too shallow to float logs. "Water and logs built up behind the dams and then were let fly in one rushing, roaring freshet." ${ }^{, 54}$

Until the turn of the twentieth century, oxen and skid roads, splash dams and flumes, single-bitted axes and chains provided the forest technology that

\footnotetext{
${ }^{53}$ Thoele, Bohemia, 19, 22-23.

54 Thoele, Bohemia, 35-36.
} 
transformed the Columbia River landscape. This technology allowed men such as Roger Atwell and Felix Iman to partner in commercial enterprises using Skamania County timber - the two men built the first passenger boat to ply the midColumbia from the Cascades to The Dalles. George Iman described "the big float": "It was huge, it's beam being about 12 or 14 feet and it's length about 40 feet. It was built of slabs, the edges of which were made straight and sized down on the bark side to fit the timbers, the sawed side out [sic]." Iman and Atwell also built the first of several steamboats constructed in the gorge. The partners launched the Mary, a seventy-seven-foot side-wheeler, in September 1853. Mr. Bush paid for the Mary, and Iman launched his own steamboat, the Wasco, in $1855 .{ }^{55} \mathrm{Jim}$ Atwell describes steamboat construction in his Columbia River Gorge History:

One of the first things needed to start building a steamboat was the boat stem. Nowadays a boat stem is laminated into the right curve. Then it was necessary to find a large tree growing on the mountainside, fell the tree, dig out the right shaped large root to be used. This stem, shaped something like boomerang, was then hauled out of the woods with a yoke of oxen down to where the steamer was to be built. ${ }^{56}$

In Skamania County, the lumber industry connected forest to river, rapidly commodifying and transforming the landscape. The steamboats constructed at the Cascades carried wood to The Dalles, where a burgeoning community stood next to a military fort and settlers descended the Oregon Trail. To obtain cash income,

\footnotetext{
${ }^{55}$ Iman in Atwell, Columbia Gorge, 67, 71; Margaret Windsor Iman, "My Arrival in Washington in 1852," Told By the Pioneers (U.S. Works Progress Administration. Vol. 1, Washington Pioneer Project. Printed under WPA Sponsored Federal Project No. 5841, 1937) 196; Iman does not say when the two built the boat, but the launch date for the steamer Mary was September 12, 1853, and Iman arrived in the gorge the previous year, so they must have built the "Big Float" at some time between 1852 and 1853 .

${ }^{56}$ Atwell, Columbia Gorge, 71.
} 
some settlers worked hauling freight on the north shore, and others found employment as woodcutters and stevedores in the developing steamboat business. Well into the twentieth century, most people provided the bulk of their own food by gardening and/or raising cattle to complement their river and forest subsistence. Making a living also included the hard work of cutting enough wood fuel to last through the winter. When farmers cleared their land, they either burned the trees or sold cordwood for cash. Elizabeth Holtgrieve recalled that her father, Henry Shepard, settled his claim where Stevenson is now because "it had the most wonderful timber he had ever seen. . . he could make a good living by cutting the wood and sending it to The Dalles." Men found work in the Columbia Gorge loading thousands of cords of wood for shipment from Shepard's Point, which later became the town of Stevenson. Louis Iman recalled the importance of woodcutting to early settlers: "A lot of people here made their living by chopping wood for fuel for the steamboats. You'd see the banks all lined with piles of cordwood."57

\section{Land Fraud, Agrarian Ethics, and Lumbering in the Wind River Valley}

Washington Territory developed through rapid migration and exploiting a multitude of natural resources - mines, farms, fisheries, and forests, and by developing transportation systems along the Columbia River. As late as 1859 , the portage road on the Washington side extended only from the Upper to the Middle Landing. Competition from a portage road developed by Joseph Ruckel on the

\footnotetext{
${ }^{57}$ Beckham, This Place, 73; "Prindle and Skamania Settled in Early Eighties," in Pioneer, Historical Edition, 5; Atwell, Columbia Gorge, 69, 77, 102.
} 
Oregon side prompted consolidation between the Bradfords, their partners, and Ruckel to form the Oregon Steam Navigation Company (OSN). Through the OSN, the Columbia River settlers partnered with many prominent Portland businessmen to monopolize river traffic during a period when efficient transport resulted in riches. Men like J.C. Ainsworth, Simeon Reed, and William Ladd, among others, benefited from gold strikes in the 1860 s that brought tens of thousands of people to the Columbia Basin interior, via the portages at the Cascades and at The Dalles. Those who lived at the Cascades relied on either employment by the OSN, working on the portage railroad or the OSN wharf, or they worked as wood choppers. ${ }^{58}$

Local prosperity at the Cascades depended on the intersection between river transport and the north shore forests. By 1860 at least thirty-two mills existed in western Washington, and only market access limited expansion. Not until late in the century did mill owners register their businesses, thus the actual number of mills in Skamania County is not clear. What is evident is that logging and lumbering, and the milling of timber became staples of the territory's economy. Owner operators established mills as close as possible to lumbering sites, moving them after depleting the timber. A direct line of the Northern Pacific Railroad across the Cascades in 1887 stimulated lumber production, and in 1888 Washington sent over 24 million board feet of lumber, more than a million lathes, and twenty-four million shingles to the east. Outside capital financed much of the

\footnotetext{
${ }^{58}$ Robbins, Landscapes, 143-144. Boats moving upriver from Portland carried 15,000 passengers in $1861,24,500$ in 1862, and 22,000 in 1863, Robbins, Landscape, 144; Schwantes, Pacific Northwest, 152; Beckham, This Place, 137-138.
} 
production, and lumber shipments reached sixteen different nations. Although domestic use took most of the cut, the export trade increased, and Washington lumber reached as far as Australia, China, and Korea. ${ }^{59}$

Skamania County settlement soon reached beyond the Columbia River and into the north shore forests of the Wind River Valley, where free land and potential prosperity drew early settlers. The DLC provided the initial inducement that encouraged homesteading, but other agrarian legislation augmented the valley's settlement. William Murphy, the first non-native settler in the valley claimed land just east of the Wind River's mouth in 1854. Others soon followed suit. Nonnative settlement began on the west side of the Wind River in the late 1870 s and early 1880 s as Thomas Monaghan, A.S. Estabrook, A.G. Tucker, and Isadore St. Martin, with some other families, settled near present-day Carson, then known as the village of Sprague. In the late 1870s, Estabrook built a water-powered sawmill on Carson Creek. Although settlers used some areas within the Wind River watershed for sheep and cattle forage, timber quickly became the most significant enterprise. According to Elsie Bloomquist, who interviewed early pioneers in 1946, "Their location gave them a short haul for timber products, as the forest then reached to the water's edge." ${ }^{\prime 60}$

In addition to the homesteaders, the budding logging industry brought a transient lumbering and laboring population to the valley. By 1880 , fifty percent of

\footnotetext{
${ }^{59}$ William Stuart Forth, "Wesley L. Jones: A Political Biography" (Ph.D. diss. University of Washington, 1962), 6, 12-14.

${ }^{60}$ Bloomquist, Pioneer Historical Edition, 3.
} 
the working population of Carson made a living in the wood products industry. Twenty-four of sixty-four men enumerated in the 1880 Sprague census worked as either loggers or wood choppers. In addition to typical logging and lumbering jobs, some worked as teamsters and others as coopers, making or repairing casks and barrels, likely for shipment of pickled salmon. Numerous communities of male workers labored for the Milton Weidler Sawmill. Seventeen men lived in a logging camp outside of Carson, with another eighteen who worked as loggers, steam engineers, and laborers living nearby. Native American women headed two of the households. Lucy Weaser lived with seventeen-year-old Sophie and thirty-year-old Jerome, a logger. Twenty-two year-old Lizzie Charlie lived next door, among wood choppers, sawmill workers, and loggers. Sawmill owner Milton Weidler lived with his twelve-year-old son Guy and sawmill clerk Eugene Clark, near the Sawmill Boarding House where another twenty-one men lived, including the mill's cook. A diverse ethnic mix comprised the ninety-four members of the Carson community. A wood chopper's camp housed ten men aged twenty-three to sixtytwo, of Swedish, Canadian, French, Irish, Scot, and American origin. The tenmember Isadore St. Martin family, who settled in the Lower Wind River Valley near a series of hot springs, was of Canadian origin, with German, Norwegian, Irish, Scot, and French neighbors. Of those not directly connected to the logging industry, nearly eighteen percent made a living in the farming industry, and the 
remaining thirty-two percent of men, aside from one sailor, labored to support the farming, wood products, and river trade industries. ${ }^{61}$

Henry Metzger, who often wrote about Carson's early days for the Skamania County Pioneer, arrived on the north shore in 1883. Metzger first lived in a small timber camp one mile west of Sprague, and in 1887 claimed land on the lower Wind River. In 1948 Metzger recalled that a steam sawmill built where Carson now stands had the capacity to saw 30,000 feet per day, and took the timber off of more than 1,200 acres. The farming that did occur took place mainly on tax exempt homesteads, recalled Metzger. The Carson Mill, the portage railroad, a steam mill in the Little White Salmon Valley, "about five miles of flumes (used for floating timber products to the Columbia River) and probably less than 2,000 acres of deeded land, much of it of little value," provided the tax base for Skamania County.

The thriving sawmill in the Wind River Valley initially shaped the community that became Carson. With the help of the mill and about $\$ 200$ from the state of Washington and Skamania County, the citizens of the valley built a school, "a miserable shack. .. of rough lumber, roof and all, braced by putting heavy planks against it on the outside." By donating labor and providing room and board for the teacher in addition to twenty-five dollars a month, Carson residents

\footnotetext{
${ }^{61}$ Watershed Analysis, I-8; Mack, "Past Human Uses," 17; "Henry Metzger Tells Story of Early Days in the Wind River Valley," From the Reminiscences of Henry Metzger, as compiled by Elsie V. Bloomquist, Pioneer Historical Edition, 3-4, 6; Hon. Daphne Ramsay, Skamania County, Washington census records: 1880 . 2nd ed. (Vancouver, WA: Clark County Genealogical Society, 1987), 1-6.
} 
educated their children. It is likely that homesteaders' and the more transient loggers' children would have viewed logging operations on a daily basis. Phoebe Yeo who lived in a regional logging camp as a child just after the turn of the twentieth century recalled that the Coulter Mill logged entirely with horses, huge percherons and clydesdales. "Oh, they just fascinated me. And then the skid road that they hauled the logs on went right by the schoolhouse," recalled Yeo. ${ }^{62}$

During the 1880s and 1890s, Wind River settlers generally applied for land under the 1862 Homestead Act, which stipulated that a claimant be either a head of household or at least twenty-one years of age, and a U.S. citizen, or someone intending to file citizenship. The homestead claimant could acquire 160 acres on any segment of the public domain by living on the land for five years, making certain improvements, and filing fees of about sixteen dollars. The claim period began once the homesteader "entered" the claim at the General Land Office. However, it was also possible to commute the entry and gain title to the land by paying $\$ 1.25$ per acre fourteen months after entry. The commutation clause created conditions conducive to abuse by providing opportunity for those with the funds to purchase lands for timber acquisition and real estate speculation.

While the sawmill helped to develop the community, it also drew timber speculation. Many who settled in the valley, claimed Metzger were "'fake' settlers, claiming the land and living on it just long enough to sell timber to the mill. Elsie

\footnotetext{
62 "Henry Metzger Writes about Early Days in the County," Pioneer, June 1948; Pioneer Historical Edition, 6; Tom and Phoebe Yeo, "An Interview with Tom \& Phoebe Yeo," interviewed by Jamie Tolfree, U.S. Forest Service (16 March 1981), 5.
} 
Bloomquist pointed out that, 'the upland settlers, who came in the late 1880s, had less fertile sod, more difficult clearing problems, and longer hauls to market their timber products." When the mill moved out in 1886, permanent settlers took up the logged over land on the lower flat of the Wind River: the Zurchers in 1885, the Metzgers in 1887, Louis Iman's family, the Glurs, Gattons, and others. By 1889 A.O. Crow, George Olmstead, Horace and C.C. Wetherell and others settled the middle flat of the Wind River. ${ }^{63}$

Long before the end of the twentieth century it became clear that public land laws courted fraud. None of the land laws promoted legal access to timber, leaving sawmill operators and lumbermen with few honest choices. Rarely did operators own enough private timberlands to sustain their operations. They could purchase timber from farmers, but usually found sources inadequate for capital gain and long-term harvest. Timber trespass became the easiest way to provide these mills with timber. To sustain operations, lumbermen went into the unregulated public forests and illegally cut the timber they needed, and false entries proliferated as timbermen entered claims under the Hometead Act. Examples of abuse abounded throughout the West. A proverbial settler could build a toy house and swear that a fourteen-by-sixteen dwelling existed, but neglect to say inches rather than feet, thus laying claim to timberlands. And many did so, under the auspices of their own private interests, or for the benefit of timber companies. Settlers commonly

\footnotetext{
${ }^{63}$ Bloomquist, Pioneer Historical Edition, 3-5; Unfortunately, fire destroyed the 1890 census in 1921, the year that, as the National Archives website points out, may have been among the most critical to historians of immigration, industrialization, westward migration, and characteristics of the general population at this important juncture. That is certainly the case in Skamania County.
} 
squatted on a piece of forested land, stripped it of timber, and then abandoned it before the patenting time elapsed. ${ }^{64}$

Settlers and timber operators in the Wind River Valley took advantage of economic possibilities through these land laws. In the 1890s the Wind River Lumber Company, located in Cascade Locks, obtained thousands of acres of private timberland through timber fraud, as did the sawmill in Carson. Sometimes companies just took what they wanted. Just before the mill on Carson Creek moved to Underwood in 1886 , the company identified a desirable stand of timber half a mile to its west. Because homestead laws disallowed selling timber for commercial purposes, the homesteaders "would not, and could not legally sell the timber." The mill, determined to obtain the wood, sent in fallers, and conflict ensued between the loggers and the homesteader when he attempted to evict them from his claim. "The next morning," according to Metzger, "when they came to work they found the road where it crossed the line fenced, and inside stood the homesteader's wife with a shotgun, threatening to 'shoot to kill' anyone who might attempt to cross the line. They left that timber alone after that. They never knew the shotgun wasn't loaded." 65

As Stephen Dow Beckham has stated: "Central to the settlement of this district. . . was its orientation to the river and the formidable obstacles that the

\footnotetext{
${ }^{64}$ Pinchot, Breaking New Ground, 80, 81; Prior, "Kinship, Environment and the Forest Service," 31 32; Cox, Changing Forests, 161.

${ }^{65}$ Metzger in Bloomquist, 4-5; Mack, "Past Human Uses," 17.
} 
Cascades presented to those seeking to pass up or down the Columbia." ${ }^{, 66}$ In addition, as this chapter argues, the area's orientation to the forests facilitated use of the river as a transportation corridor and commercial waterway, and westside forests provided the infrastructure for taking advantage of the region's possibilities. This strategic orientation made the Columbia's north shore not only desirable, but also necessary to settlement of the Pacific Northwest because this transportation corridor connected the east and west sides of the Cascade Mountains.

The main obstacle to Euro-American control of the region, however, was not the physical, but the social landscape. In an ironic twist of fate, the Americans' disease pathogens cut through the very fabric of native culture, impacting the native relationship to the Cascades and the nearby forests through death and oppression. Estimates of population loss along the mid-to-lower Columbia River range from ninety-two to ninety-eight percent Pestilence demoralized native peoples enough that the government met with only minimal resistance. By destroying the settlers' built environment at the Cascades in the mid-1850s, native peoples demonstrated resistance to two critical elements of Jeffersonian democracy - a capitalist ethos and American progress - both of which ultimately transformed the physical and cultural landscape of Skamania County.

The agrarian ethic visible in land acquisition laws promoted the individual search for a better life, but in the Columbia Gorge timber and water dominated the landscape, and settlers found distinct opportunities. Commercial operations

\footnotetext{
${ }^{66}$ Beckham, This Place, 73.
} 
harvested timber for railroad ties to construct the portage railroad and build steamboats as they milled lumber for export, and to construct homes and towns. Settlers made subsistence use of the forests, harvesting berries, salmon, nuts, and wood for personal use as villages sprouted along the north shore of the Columbia. Wood from the north shore quickly became an export item, and selling cordwood an alternate individual income strategy.

By the end of the century, it had become clear that the landscape of southern Skamania County clashed with the Jeffersonian ethos, with commercial opportunities outpacing the agrarian impulse. The values that formed the American character manifested a dark side as the federal government removed Indian people from their homelands, replacing them with American migrants in a complex reconfiguration of power and place. In the Willamette Valley of Oregon, farms quickly dotted the countryside. In Skamania County, sprouting sawmills transformed the landscape, removing much of the timber along the Columbia and in the lowlands of the Little White Salmon and Wind River Valleys by 1890. Residents used public land laws to access timber, relying on legal entrance into public forestlands until the federal government increased regulation near the end of the century. As rising industrialism, access to world markets, and more sophisticated technology began to reshape western forests, national conservation efforts increased and conflict over resource control developed in Skamania County. The ensuing debate that began at the turn of the century contributed to the 
community character and economy in ways that continue into the twenty-first century. 


\section{CHAPTER THREE: PROGRESSIVE CONSERVATION, TREE FARMING AND THE "IDEA" OF FORESTRY}

\section{The Roots of Forest Conservation}

The idea of abundant, inexhaustible natural resources is among the most persistent notions in American history. Thick flocks of birds, abundant forests, and multitudes of fish astounded seventeenth century New Englanders. When Europeans arrived in the New World, over 850 million acres of forest reached from the Atlantic to the Pacific. This was not virgin land. Indigenous peoples used these forests extensively, and open, park like meadows dotted the wooded lands. However, by the end of the eighteenth century, what environmental historian Carolyn Merchant deems a capitalist ecological revolution had already taken place in the East and the burgeoning lumber industry depleted its own resource base and headed west. By the mid-nineteenth century, the pattern of resource depletion repeated itself in the lake states and Wisconsin. Sawmills sprouted, loggers stripped river banks, and lumber companies moved on to the next stand.

Of greater consequence than the idea of abundance, writes forest historian Harold Pinkett, is the fact that early Americans used resources as though they were inexhaustible. "By the close of the nineteenth century a great drain had been made on this great natural wealth. Much of the depletion had come in the name of national development." Two major aesthetic and social theories dominated Americans' approach to their environment through the first half of the nineteenth century. A sublime romantic notion of nature, rooted in contemplation, provided 
the foundation for a "preservationist" ethic. Emphasis on a productive nature - the Jeffersonian ideal - located democracy and national prosperity in the clearing and cultivation of the wilderness. In addition, by the end of the nineteenth century, science reigned supreme. Thus, a "conservationist" ethic rooted in resource use, a growing sense of diminishing resources, and a scientific approach, constituted what is now referred to as the Progressive Conservation era. ${ }^{1}$

Progressive Conservation actually began mid-century as arguments grounded in science and the idea of interrelated ecosystems gained acceptance. In 1864 George Perkins Marsh published Man and Nature, bringing attention to the scientific need for conservation. Although Marsh's was mainly a social argument, he pointed out that humans are the only animals that exceed their basic needs and destroy the environment in the process. Marsh also brought attention to the complexity of ecosystems. ${ }^{2}$ Although the later conservation approach differed, he asserted some of the primary arguments for forest management. Forests provided flood control, impacted climate, and encouraged rainfall. The General Land Office (GLO), the government agency responsible for public lands distribution, adopted Marsh's approach. In the 1868 GLO report, the land commissioner included twenty-six pages on the importance of forests. He cited Marsh as an authority three

\footnotetext{
' Carolyn Merchant, Ecological Revolutions: Nature, Gender, and Science in New England (Chapel Hill: University of North Carolina Press, 1989), 224; Harold K. Steen, "Forestry in Washington to 1925" (Ph.D. thesis, 1969), i; Harold T. Pinkett, Gifford Pinchot: Private and Public Forester (Chicago: University of Illinois Press, 1970), 7; William Cronon, Changes in the Land: Indians, Colonists, and the Ecology of New England (New York: Hill \& Wang, 1983), 22, 23, 25; Cox, Changing Forests, 156.

${ }^{2}$ Donald Worster, Nature's Economy: A History of Ecological Ideas (New York: Cambridge University Press, 1977, reprint, 1988), 269.
} 
times, recognized the storage capacity of large trees, discussed erosion control provided by forests, and pointed out the importance of maintaining a "proper ratio" between field and forest.

Attention to resource depletion, especially through timber speculation, sparked legislative action and social debate through the last third of the nineteenth century. In 1866, the U.S. Commissioner of Agriculture issued a warning regarding forest demise. Several prairie states encouraged forest planting through tax exemptions and bounties, the "tree planting" movement that brought about Arbor Day in Nebraska in 1872. Reflecting the nation's agrarian impulse, by 1873, the Timber Culture Act allowed homesteaders to plant and grow a forty-acre tract of land for eight years and then receive patent to an entire quarter-section. Unfortunately, the act resulted in claims filed in order to strip land of timber. In the 1870s, John Muir, the well-known Scottish nature lover and wilderness advocate, decried decimation of forests, "most precious and indispensable." Mineral lands would continue to exist and soils could be replenished, but forests, wrote Muir, “.. . are threatened with utter destruction, and when once destroyed, can never be wholly restored." If the government fully appreciated their value, their contribution to climate, flood protection, and formation of the "fountains for the irrigating rivers," they would be guarded rather than left exposed to the vagaries of sheepherders and timber barons. Muir regarded lumber mills as "the centers of desolation," but sheep constituted the root of forest evil. Sheep trampled the ground, ate the forest bare, devoured shrubs, budding leaves, and even small 
conifers; and sheepherders, according to Muir, set nearly ninety percent of the fires that devastated forests beyond repair. ${ }^{3}$

Proposed solutions to forest destruction began with inventories, studies, and calls for government intervention. In the 1870 s, Muir proposed a forestry commission for woodland protection, calling for a halt to forest use above 6000 or 7000 feet. The combined outcry led to Congressional investigation in 1876 . The resulting study of forest conditions under Franklin B. Hough in the Department of Agriculture provided the seeds of national forest administration. With additional support from people like Secretary of Interior Carl Shurz, the study resulted in creation of the Forestry Division in the Department of Agriculture in 1881.

Hough's concern for future generations included recognizing that resources were indeed exhaustible: ". . . the idea of conserviency of forests, or the wants of the future, are entirely overlooked in the anxiety to satisfy the current wants of the present time." Hough advised controlled management of federally owned timber, fire protection, establishing forest experiment stations, and appointing Europeantrained foresters to manage the forests. In his 1877 report of the Secretary of Interior, Schurz pushed for protective legislation for forestlands. He noted that protecting timber was a question of law, and public economy, and that an enormous amount of timber had been stripped from public lands without authority, not only for personal use, but also for commercial purposes. Schurz recommended that in the interests of the future, all timberlands still part of the public domain "should be

\footnotetext{
${ }^{3}$ Cox, Changing Forests, 164, 165; Steen, "Forestry," 5-7; Muir quoted in Robert Engberg, "John Muir's 'Great Evils from Destruction of Forests'," The Pacific Historian (Summer 1981), 12, 14.
} 
withdrawn from operation of the pre-emption and homestead laws, a sufficient number of government agents should be provided to prevent stealing timber, and criminal as well as civil action should be instituted against the depredators. For the 1870s," writes Pinkett, "these were audacious recommendations."4

Harold Steen sums up of the prevailing nineteenth century temperament:

The general view of inexhaustible resources, the prevalent short-term practical view of progress, the belief that good was committed by clearing and settling land, the rapidly growing economy and the ever increasing rate of immigration adding to the population, all contributed to wasteful exploitation of resources, including forest resources. ${ }^{5}$

At the same time, the American emphasis on agriculture created different attitudes toward timber depletion than other resources. "Land was to be cleared and cultivated, not exploited and abandoned." The effects of wasteful lumbering, unlike the absence of beaver or minerals, were visible. Studies concluded that maintaining a favorable climate depended on forests, as did erosion and flood control. Ultimately, and in keeping with agrarian ethics, the government viewed timber as a renewable crop that could produce a continuous supply of lumber. ${ }^{6}$

In 1886, Bernhard E. Fernow, a German-trained forester, became head of the Forestry Division. Fernow's training in scientific forestry, according to historian William Robbins, "heralded the federal government's increased awareness of the importance of the woodland environment and forest products to a modern capitalist

\footnotetext{
${ }^{4}$ Muir quoted in Engberg. "John Muir's Great Evils," 14; Harold T. Pinkett, "Western Perceptions of Forest Conservation" Journal of the West 28, 4 (Oct. 1979), 72; Pinkett, Gifford Pinchot,

Forester, 9, 10; Franklin B. Hough quoted in Steen, "Forestry in Washington, 9; Carl Schurz, "The Beginnings of Federal Concern," in Roderick Frazier Nash, American Environmentalism: Readings in Conservation History (McGraw Hill, Inc., 1990), 59-62.

${ }^{5}$ Steen, "Forestry in Washington," 4.

${ }^{6}$ Steen, "Forestry in Washington," 15-16.
} 
economy." Fernow connected "enormous waste...[a] spirit of speculation... [and] enormous profits" with public lands laws conducive to agriculture, and no regulation for private timber holders. In an attempt to administer forestlands for conservation of resources, and to show private landowners that scientific forestry would be "directly profitable," in 1888 Fernow unsuccessfully introduced legislation to create forest reserves. ${ }^{7}$

These efforts to conserve forest resources and prevent fraud ultimately reframed forest use and management in the west as attitudes toward forest resources and public land management shifted. The critique of the public lands system was part of a broader movement for social reform, Progressivism, that began in the tenements and factories of the east, where tuberculosis killed the poor, corporations and smaller businesses exploited workers, and political machines determined elections. Progressivism started with protest against the industrial order and addressed many areas: the increasing power of corporations, widespread corruption, efforts to increase efficiency in economic and political life, attempts to make business more accountable and government more responsive to the needs of people, and a moral urge to rid society of the evils of prostitution and alcohol. Progressivism also included a movement toward preservation and conservation of forest resources.

\footnotetext{
${ }^{7}$ Ibid; William G. Robbins, "Federal Forestry Cooperation: The Fernow-Pinchot Years" Journal of Forest History 28, 4, (October 1984) 165; Fernow quoted in Robbins, "Federal Forestry, 165, 166; William G. Robbins, American Forestry: A History of National, State, \& Private Cooperation (Lincoln: University of Nebraska Press, 1985), 16; Pinchot, Breaking New Ground, 84.
} 
By 1891, Congress began to reshape political, economic, and social boundaries in the forests of the Pacific Northwest by passing legislation that withdrew public lands for forest reserves. In 1893 President Benjamin Harrison proclaimed the Pacific Forest Reserve, and in 1896 Gifford Pinchot visited the Northwest with the National Science Academy Forest Commission. The report prepared by Pinchot added more than one million acres to the Pacific Forest Reserve in 1897, placing most of Skamania County under federal management. Although national public sentiment favored forest preservation, many local residents in western communities, and in Skamania County, protested. ${ }^{8}$

Two figures more than any others, John Muir and Gifford Pinchot, characterized the schism that had developed in terms of the human relationship to nature by the end of the nineteenth century. In many ways, the two had much in common. Both were passionately committed to defending the natural world, both reveled in outdoor activity and sought to protect the environment from depredation. Both wanted to protect the nation's forests, and at one time the two men were friends. Muir promoted national parks, while Pinchot promoted national forests. Muir founded the Sierra Club to protect natural areas from use, while Pinchot founded an organization to make what he considered efficient and wise use of nature. However, their philosophies differed, ultimately pitting them against one another in a battle over the Hetch-Hetchy Dam in California. By the time he died in 1914, Muir the romanticist had come to epitomize the preservationist arm of the

\footnotetext{
${ }^{8}$ Pinkett, Gifford Pinchot, 41; Pinchot, Breaking New Ground, 107; McClure \& Mack, For the Greatest Good, 12.
} 
conservation movement. Pinchot symbolized the utilitarian sector of Progressive conservation, those who would ultimately triumph in shaping national forest development and use throughout the west, and in Skamania County. ${ }^{9}$

While Muir exerted tremendous influence in the movement to preserve wilderness, it was Pinchot, the passionate, zealous proponent of Progressivism, friend of Theodore Roosevelt, and antitrust advocate, who would wield the most influence over resource use in the twentieth century. Muir's beautiful tomes on the West inspire awe. His writing includes "Steep Trails," a poetic description of western forests including Oregon and Washington. ${ }^{10}$ But Pinchot, who coined the phrase, "the greatest good for the greatest number for the long run," captured and implemented a lasting national utilitarian policy that ultimately Muir disdained. ${ }^{11}$ Pinchot exerted tremendous influence in creating the idea of "practical" forestry, an idea grounded in notions of efficiency, utility, and Progressivism. Pinchot explained his views in his autobiography, published in 1947:

The first Progressive victory was won in a fight to prevent the monopoly of natural resources, and it is one of the proofs of my contention that Conservation is the heart of the Progressive movement. You ask why? Because, for one thing, Conservation is the most effective weapon against monopoly of natural resources, and monopoly of resources is the basis for the conservation of wealth in the hands of a few. In a democracy that is the fundamental evil. That is what Progressives fight. Under T.R. and later under Taft the Conservation issue brought more Progressives together than any other issue. ${ }^{12}$

\footnotetext{
${ }^{9}$ For an excellent overview of the relationship between Pinchot and Muir, see, Char Miller, Gifford Pinchot and the Making of Modern Environmentalism (Washington D.C.: Island Press, 2001), 119144.

${ }^{10}$ See, "Steep Trails," in John Muir: The Eight Wilderness Discovery Books, introduction by Terry Gifford (London and Seattle: Diadem and the Mountaineers, Seattle), 865-1012.

${ }^{11}$ Miller, Gifford Pinchot and Environmentalism, 121.

${ }^{12}$ Pinchot, Breaking New Ground, 464.
} 
Clearly Pinchot wanted to be viewed as a moral crusader against injustice, someone who reserved resources for the use of the people rather than large-scale capitalist monopolies. Pinchot claimed to view conservation essentially as a matter of equity, opting for material benefits for the many through public use, rather than preservation of the natural world for the few. Pinchot spent his life working for conservation, calling for an international conservation congress in 1946. However he passed away and the conference did not take place. Ironically, Pinchot's conservation policies would ultimately contribute to the success of the wealthy resource corporations. ${ }^{13}$

Pinchot's education and study of forestry in Europe, where centuries of resource exploitation had made conservation necessary, helped him to shape a liberal philosophy in which he believed that government management would best protect, preserve, and utilize America's natural resources. Like many young people, Pinchot faced indecision as he headed off to Yale in 1885, deciding between medicine and the ministry. As a boy in the 1860s and 1870s, Pinchot loved camping, fishing, he "loved the woods and everything about them," and when his father suggested forestry as a profession, young Gifford agreed. For his twenty-first birthday he received a copy of George Perkins Marsh's The Earth as Modified by Human Action. At Yale he took courses in meteorology, astronomy, and geology, but, as he later wrote, "as for Forestry itself, there wasn't even a suspicion of it." During the winter of his senior year, 1888-1889, Pinchot went to

\footnotetext{
${ }^{13}$ Miller, Gifford Pinchot and Environmentalism, 141. See Char Miller regarding the political and philosophical schism in the conservation movement.
} 
Washington D.C. and consulted with national heads of forestry including Dr. Bernhard Fernow and Charles S. Sargeant, head of the Arnold Arboretum and forest preservation advocate. Both men became his mentors and encouraged him to pursue a career in forestry. ${ }^{14}$

Warned by Fernow that the study of forestry should be "second fiddle" to a career in botany, landscaping, or gardening, Pinchot decided to go abroad to "find out" about forestry. At a French forestry school in Nancy, he embarked on a field of study including: 1) silviculture or how to grow trees; 2) Forest Organization, or the economics of forestry, "in general with how to get out of the forest the most of whatever you want."; and 3) Forest Law, useful even though it was French law. ${ }^{15}$ After touring Europe and studying German forestry, at the end of 1890 Pinchot returned to the United States to begin his career as a forester. Pinchot recalled that "The Nation was obsessed, when I got home...by a flurry of development," that exploited and appropriated natural resources, and opened new territory at home and abroad. ${ }^{16}$

And still no forestry conservation, only liberal public land laws effectively promoting private ownership of forest lands where the rule was "Get timber by hook or crook, get it quick and cut it quick, " the rule of the citizen. "Get rid of it quick - that was the rule of the Government for the vast timberlands it still

\footnotetext{
${ }^{14}$ Miller, Gifford Pinchot and Environmentalism, 55, 141.

${ }^{15}$ Pinchot, Breaking New Ground, 2, 3, 6, 10.

${ }^{16}$ Pinchot, Breaking New Ground, 23.
} 
controlled."17 The 1890s began without systematic forest management. The Interior Department managed public lands, including forests, while the Department of Agriculture's Bureau of Forestry had only forests to study, but none to manage. Pinchot returned from Europe ready to implement what he had learned. Reflecting the pervasiveness of the agrarian ethic, Pinchot laced his forestry philosophy with agricultural rhetoric:

Forestry is Tree Farming. Forestry is handling trees so that one crop follows another. To grow trees as a crop is Forestry....

.... what the forester gets is a crop - his crop, although he may not live to see it harvested. It takes more time and less attention to grow a crop in the forest than it does on the farm. That is the main difference.

.... A well-handled farm gets more and more productive as the years pass.

So does a well-handled forest. ...

The purpose of Forestry, then, is to make the forest produce the largest possible amount of whatever crop or service will be most useful, and keep on producing it for generation after generation of men and trees. ${ }^{18}$

Pinchot's tree farming evokes the very different haptic sense of garden and forest.

The former is valued for its use, the latter more for spiritual value than material benefit. Pinchot's efforts to create tree farms depended very much on his own perceptions of the forests, a utilitarian view that differed significantly from the spiritual and biotic view of men like John Muir, Charles Sargent, and Bernhard Fernow. $^{19}$

Within only a short time, Gifford Pinchot's tree gardens would begin to take hold. Before implementing "Forestry" as he saw it, Pinchot had to gain credibility as a forester. He quickly put his scientific forestry training to use running the

\footnotetext{
${ }^{17}$ Ibid.

${ }^{18}$ Pinchot, Breaking New Ground, 31-32.

${ }^{19}$ Miller, Gifford Pinchot and Environmentalism, 131-132.
} 
privately owned Biltmore Forest near Asheville, North Carolina when he returned to the United States. Pinchot immediately mapped the 7,000 acre forested estate, trained logging crews in selective cutting methods, and prepared a six-year working plan. He showed a $\$ 1,200$ profit the first year. ${ }^{20}$ By 1905 , as the political climate caught up with his goals, Congress created the U.S.D.A. Forest Service. Gifford Pinchot became the first head of the Forest Service, and he more than any other shaped the controversial use-based forestry practices that lasted until the end of the twentieth century.

\section{Legislating the Forests}

The foundation of a U.S. national forest system that effectively placed fourfifths of Skamania County under federal regulation began with the Forest Reserve Act, or Noble-Bowers Amendment. This act of March 3, 1891 repealed the Timber and Stone Act, and authorized the president to create forest reserves by proclamation. As Harold Steen points out, until the 1878 Timber and Stone Act, Congress did not recognize forest land as distinct: "Land was either agricultural land, or land not suited for agriculture. The first job of the settler was to make ready for his crops. If he could not create a productive farm, then the land was not considered suitable for anything and was generally ignored by Congress."21 However, timber fraud plagued Timber and Stone claims, and large portions of the

\footnotetext{
${ }^{20}$ Pinchot, Breaking New Ground, xvi.

${ }^{21}$ Steen, "Forestry," 19.
} 
public domain had been transferred to railroads, states and individuals. "Thus," claimed Pinchot:

... the natural resources, with whose conservation and wise distribution and use the whole future of the Nation was bound up, were passing under the control of men who developed and destroyed them with one and only one object in mind - their own personal profit. And to all intents and purposes the Government of all the people did nothing about it. ${ }^{22}$

The intent of the Noble-Bowers Amendment, suggested by Secretary of the Interior John W. Noble and special land office agent Edward A. Bowers, was, according to Pinchot, twofold: 1) to stop the unintended redistribution of forest lands for corporate profit; 2) To protect federal lands from fire. Implementing the ForestReserve Act meant informing the public, and notices on forest reserve boundaries stated:

All persons are hereby warned not to settle upon, occupy, or use any of these lands for agricultural, mining, or other business purposes; nor to cut, remove, or use any of the timber, grass, or other natural products thereof, except under such regulations as hereafter may be prescribed. ${ }^{23}$

The immediate effect of "reserving" the forests was to withdraw them from public use until additional legislation made them more available six years later. By September 1893, Presidents Harrison and Cleveland had proclaimed seventeen forest reserves totaling eighteen million acres, but with no method of administration or way for Americans to access lands and resources. Restrictions on mining, agriculture and settlement especially engendered opposition. In addition, many contended that the reserved forests obstructed industrial and domestic power

\footnotetext{
${ }^{22}$ Pinchot, Breaking New Ground, 82.

${ }^{23}$ John Fedkiw, "National Forests and the Performance of the Organic Act of 1897," Forest History Today (1998), 13.
} 
development. As Pinchot declared, no roads could be built, no forage could be grazed, no minerals could be extracted, no timber could be cut, and "without lumbering there could be no development. So they took what they had to have, and public opinion sustained them."24

However, the forest conservation movement had supporters as well. Largescale federal forest policy had its roots in the west. Scenic preservationists petitioned for early withdrawals of national park lands in the 1870 s and 1880 s, and at least three states asked for forest reserves before the Forest Reserve Act: "Colorado in 1876, California in 1885, and Oregon in 1889." Reserves did not come about through executive whim. Most were created as a result of petitions from local citizens. The main dissatisfaction stemmed from lack of legal access to resources. The Progressive Pinchot viewed locking up public resources as unjust. He also realized that without systems in place for industrial resource access, the government courted fraud, and illegal use prevailed. Both Pinchot and President Cleveland remained dissatisfied with the existing system. After 1893 the president refrained from creating any more forest reserves and awaited Congressional management guidance. ${ }^{25}$

In an effort to regulate and assess forestlands for future reservations, President Cleveland called for a forest reserve administration plan. On February 15,1896 , Secretary of Interior Hoke Smith sent a letter to Wolcott Gibbs, head of

\footnotetext{
${ }^{24}$ Pinkett, "Western Perceptions," 72-73, Pinchot, Breaking New Ground, 86.

${ }^{25}$ Lawrence Rakestraw, "Uncle Sam's Forest Reserves" Pacific Northwest Quarterly 44, 4 (October, 1953), 145-146; Fedkiw, "National Forests," 13.
} 
the National Academy of Sciences, asking the Academy to address forest reserves. In response, Gibbs formed a National Forest Commission to determine: 1) who would have ultimate ownership of the forests then part of the public domain, and how much forest land would pass into private ownership; 2) how government forests would be administered so that nearby inhabitants could access resources without affecting the forests' permanency; and 3) what provisions the government would make to manage the forests. The way Pinchot saw it, the first question meant Forest Reserves, the second meant use, and the third meant professional forestry. Commission Chairman Charles S. Sargent, Harvard University professor of botany, and founder and supporter of Garden and Forest, made the 31-year-old Pinchot secretary of the commission. Other participants included Henry L. Abbot, army engineer and an authority on the physics and hydrology of streams, Alexander Agassiz, Curator of the Harvard Museum of Comparative Zoology, Professor William H. Brewer of Yale, and Arnold Hague, a geologist and geologic explorer. ${ }^{26}$ Gibbs and Sargeant chose Pinchot because of his scientific forestry training and experience, and because they supported his career. Although not a member of the National Academy, he had already made a name for himself. In the Biltmore Forests, through paper presentations at American Forestry Association meetings and by publishing in Garden and Forest, Pinchot proved a young man with a vision. He left for the west on June 1, 1896, taking Harry Graves with him at his own expense. Soon, writes Pinkett, Americans "were not to forget his name,

${ }^{26}$ Pinchot, Breaking New Ground, 90-92; Pinkett, Gifford Pinchot, 39. For Pinchot's account of how the Forestry Commission came about, see Breaking New Ground, 86-93. 
because from that time onward through half a century it was to be continually associated with all efforts to protect and manage forests and the related natural wealth of America." 27

He and Graves started on what Pinchot described as a thrilling journey. They studied forests in the Blackfoot region of the Rockies and brought about the Flathead Reserve, and later Glacier National Park. A trip up the valley of the Swan River and between the Kootenai Mountains on the east and the Mission Range to the west, a "fairy land, in spite of the mosquitoes" led to the Lewis and Clark Reserve. On July 16, 1896, Pinchot met the Commission - Sargent, Brewer, Hague and Abbot - in Belton, Montana. John Muir, and Lieutenant George P. Ahern, who taught forestry in Montana, joined them as the Commission set out to examine the Bitterroot Valley, then headed to Portland, Oregon. Through the Willamette, Umpqua and Rogue River Valleys, Pinchot argued policy with Sargent. Pinchot and geologist Arnold Hague felt the forests should be for use, and protection and regulation should be accomplished through a civil service. Sargent, Muir, and Abbott all believed that only by closing the reserves to development could they be preserved, and the army should provide the protection. ${ }^{28}$

Still the commission members enjoyed their western trek. Pinchot recalled that he and Graves traveled with commission members from Ashland, Oregon to Klamath Lake to Crater Lake, "while John Muir and Professor Brewer made the

\footnotetext{
${ }^{27}$ Pinkett, Gifford Pinchot, 41.

${ }^{28}$ Miller, Gifford Pinchot and Environmentalism, 136.
} 
journey short with talk that was worth crossing the continent to hear. ${ }^{, 29}$ As Graves went with Muir to the Oregon Cascades to study the growth rate of Douglas fir and the effect of sheep grazing on the forest, Pinchot headed to the Sierra Nevadas. From California through Arizona, New Mexico, and Colorado, the Commission identified potential forest reservations and studied various ecological zones, returning east to deliver a forestry plan to President Cleveland.

In October, the Forest Commission recommended creating a number of new reserves and the Mount Rainier and Grand Canyon National Parks. Pinchot protested the military forest management plan proposed by Abbot and Sargent, resulting in a lasting split between the men. The young forester wanted to put a forest management system in place, and then create further reserves. However, the Commission voted otherwise, and the draft report sent to Professor Gibbs in January 1897 recommended thirteen new reserves. The report, in turn, went to President Cleveland, who on February 22, 1897, ten days before leaving office, reserved over 21 million acres of forest lands. Just before leaving office Cleveland more than doubled the existing seventeen-and-a-half million acres of reserves without public notice, Congressional approval, or input from western legislators. The reserves included the Priest River Reserve in Idaho and Washington, 645,120 acres; Washington Forest Reserve in Washington, 3,594,240 acres; Olympic Forest Reserve in Washington, 2,188,800 acres; and Mount Rainier Forest Reserve in Washington. The Forest Commission visited the Puget Sound region, traveled

\footnotetext{
${ }^{29}$ Pinchot, Ibid,97-98, 100-101.
} 
down the Columbia River, and saw the forests of Oregon, but they did not visit southwestern Washington. Still, the report prepared by Pinchot added 1,267,200 acres to the previously set aside Pacific Forest Reserve, placing eighty percent of Skamania County under federal management. ${ }^{30}$

"The creation of the thirteen new Reserves in seven states came like a thunderclap," recalled Pinchot. No use could be made of the reserves and it was even illegal to step foot in them. With the vast forests locked up, it was "No wonder the West rose up." ${ }^{\text {31 }}$ A struggle between western congressmen and conservationists ensued. Senator Clarence D. Clark of Wyoming offered an amendment to nullify the Cleveland proclamations and restore the reserves to the public domain. The amendment passed the Senate, but Congressman John F. Lacey of Iowa introduced a substitute into the House. The Secretary of the Interior would be authorized by the Lacey Amendment to:

make sales of timber on any forest reservations, now or hereafter proclaimed, for mining and domestic purposes, under such regulations as he may prescribe, and to make all needful rules and regulations in furtherance of the purposes of said reserves, for the management and protection of the same."

The Lacey Amendment also ordered the elimination from the forest reserves of lands more valuable for agriculture and made the reserves free to mineral development. The fight put the reserves "on the brink," pitting eastern congressmen against western congressmen. The bill passed the House, but the last

${ }^{30}$ Ibid, 102-107; Pinkett, Gifford Pinchot, 41; Richard McClure and Cheryl Mack, For the Greatest Good: Early History of Gifford Pinchot National Forest (Vancouver, WA: Northwest Interpretive Association, 2000), 12.

${ }^{31}$ Pinchot, Breaking New Ground, 109. 
clause removed presidential authority to create reserves. Cleveland vetoed the legislation. As William McKinley came into office in March 1897, the fight renewed in Congress. ${ }^{32}$

McKinley supported the reserves, and in 1897 Congress passed the Organic Act, which opened the forest reserves to use and management, including the sale of timber. The act set forth the paradoxical conditions of protection and use, establishing long lasting national forest management guidance with the following statement:

No public forest reservation shall be established, except to improve and protect the forest within the reservation, or for the purpose of securing favorable conditions of water flows, and to furnish a continuous supply of timber for the use and necessities of the citizens of the United States; but it is not the purpose of these provisions, or of the Act providing for such reservations, to authorize the inclusion therein of lands more valuable for the mineral therein, or for agricultural purposes, than for forest purposes. ${ }^{33}$

The Secretary of the Interior would be in charge of reserve administration, would make rules and regulations to regulate the forests, and would preserve them from destruction. That was, according to Pinchot, "the milk in the coconut" that made forest protection and management possible. The act specifically allowed the Department of Interior to sell "the dead, matured, or large growth of trees," after they had been "marked and designated." The act provided for free use of reserve timber and stone at the discretion of the Interior Secretary "by bona fide settlers, miners, residents, and prospectors for minerals, for firewood, for fencing, buildings, mining, prospecting, and other domestic purposes." Pinchot complained

\footnotetext{
${ }^{32}$ Pinchot, Breaking New Ground, 109-113.

${ }^{33}$ Fedkiw, "Organic Act," 13.
} 
that "firms, companies, and corporations [were] not ruled out," despite earlier efforts to exclude them. Most problematic was the lieu-land clause, which provided for what was essentially a land trade. A "settler or owner" could relinquish lands held within the reserve and select lands outside the reserve "in lieu thereof." This would allow large landowners such as lumber, mining, and railroad interests to get rid of their cut-over, used-up lands in exchange for more valuable lands on the public domain. ${ }^{34}$

\section{Examinations and Boundaries}

With millions of acres of forestland suddenly available for use under government control by the Organic Act, the question remained: how to administer them? Should a military service administer the forests or a civilian, nonpartisan, nonpolitical service? Initially, the reserves remained under keep of the Secretary of Interior, with the General Land Office in charge of on-the-ground administration. The Forestry Division in the Department of Agriculture under Bernhard Fernow, functioned mainly as an information bureau, focusing on scientific forestry, establishing state forestry agencies, educating the public, facilitating silvicultural experimentation, and studying fires. Under the Organic Act, government officials laid plans in 1897 to manage and expand forest reserves. Secretary of Interior Cornelius Bliss hired Gifford Pinchot as Confidential Forest Agent, a position the members of the National Academy of Sciences viewed as a purely political

\footnotetext{
${ }^{34}$ Pinchot, Breaking New Ground, 116-118; Fedkiw, "Organic Act," 13; Pinkett, Gifford Pinchot, 42.
} 
appointment. During the summer of 1897 Pinchot headed west to examine and report on the needs of the suspended reserves, their condition, their future increase or decrease, and to assess their relation to lumbering, mining, grazing, commerce, and settlement. In addition, the Secretary charged him with drawing up a practicable plan for establishing a Forest Service with specific recommendations for individual reserves, a plan that he would be able to implement almost immediately when the time came. ${ }^{35}$

Pinchot began his examinations as Confidential Forest Agent on July 10, 1897, heading first to Priest Lake Forest Reserve in Idaho. From there, he went to Spokane where he met with the editor of the Spokesman Review, Will Cowles, a friend from Yale. "To him I went with my story that the Forest Reserves were made to be used, not just to look at; asked for his help; and got it. Next day appeared a long interview in his paper and an editorial backing up my point of view." From Spokane to Wenatchee, then up the Columbia River on the east side of the Cascades to Lake Chelan and Bridge Creek, Pinchot examined the reserves, hunted, and talked to loggers, miners and settlers. Frederick H. Newell, later head of the Bureau of Reclamation, and Henry Gannett of the geological survey joined him at Bridge Creek. Next they traveled to Horseshoe Basin, stopping to collect a mountain goat, through the Cascade Pass, and down to the Skagit River.

In part, the trip became a publicity tour to gain support for the reserves. Pinchot headed off to Seattle where he discussed Washington State public opinion

\footnotetext{
${ }^{35}$ Robbins, American Forestry, 8-11; Pinkett, Gifford Pinchot, 47; Pinchot, Breaking New Ground, 123; Miller, Gifford Pinchot and Environmentalism, 143.
} 
with Judge Thomas Burke. He claimed he convinced Judge Burke that the forest policy was "wise and right," and the judge took him to the editor of the Post Intelligencer, who "came to the right view" after interviewing Pinchot. Having seen something of both the east and west slopes of the huge Washington Reserve (three-and-a-half million acres), he set out to visit the Olympic Reserve. The number of huge trees - many at least 275 feet high - of the Olympic Reserve amazed Pinchot, and he commented on the Western Hemlock which stood "in crowded rows on nearly every fallen log." The impact of fire most impressed the young forester as it had John Muir the previous year, imbuing the men with a distinct sense of place. Both noted that fire, the "great governing agent," conditioned and controlled the Olympic forests. ${ }^{36}$

Pinchot headed to Montana for further examinations, but never visited the reserved lands in Skamania County. From Custer, Montana, on November 15, he reported to the Secretary "a general change of opinion in regard to the Reserve, both among the ranchers and among those interested in mining. So far I have talked to no one who was not strongly in favor of preserving the timber." All parties in the commission witnessed the impact of fire on the forested landscape, providing further justification for forest reserves. For Pinchot, the main import of the trip was that through contact with local newspapers he learned to direct and create public opinion. This knowledge of the media would serve him well when he took on a new position as first, head of the Division of Forestry and later, first

\footnotetext{
${ }^{36}$ Pinchot, Breaking New Ground, 125-128; Muir, "Steep Trails," 959.
} 
Chief of the U.S.D.A. Forest Service. Fernow, who also disagreed with Pinchot's approach to forestry, and doubted the practicability of forest management by the federal government, resigned on May 11, 1898. Gifford Pinchot enthusiastically became head of the Division of Forestry, still without forests to manage, but with increasing power to shape the administration and jurisdiction of federal forestry. After his western trip Pinchot felt it imperative to establish permanent boundaries for the reserves and a professional forest service to manage the resources. He also recommended eliminating land more valuable for agriculture than forestry from the reserves, but it would take another eight years to develop a forest administration and land classification system to determine agricultural lands. First, the reserves must have boundaries. ${ }^{37}$

The act of June 4,1897 , had appropriated $\$ 150,000$ for surveying and classifying forest reserve lands by the U.S. Geological Survey, with Henry Gannett in charge. A friend of Pinchot's, Gannett allowed the thirty-two year old forester to participate in issues concerning boundary changes. Gannett not only mapped the reserves, he estimated the size of forest stands inside their boundaries working closely with men from the Division of Forestry. In 1901, under the Theodore Roosevelt administration, Congress advanced the Division of Forestry to Bureau status, giving the agency more influence with the Department of Agriculture. The agency remained in the Department of Interior, with forestry education and study as

\footnotetext{
${ }^{37}$ Pinchot, Breaking New Ground, 130; Pinkett, Gifford Pinchot, 45, 47; Robbins, American Forestry, 2; See Char Miller, Gifford Pinchot and Environmentalism on the Pinchot, Fernow, Sargent split, 141-143.
} 
its mandate for another four years. Not until 1905 would the Bureau of Forestry transfer to the Department of Agriculture, and begin to actually manage forests under the new U.S.D.A. Forest Service.

During the reseve period, the General Land Office (GLO) of the Interior Department began to establish concrete forest reserve boundaries in the Pacific Northwest, both to withdraw agricultural lands from the reserves and to add to the existing reserves. Fred G. Plummer of the U.S.G.S. with assistance from Harold D. Langille did the boundary work in Oregon and Washington in the spring of 1900. They examined the Cascade Mountain area of Central Washington between the Mount Rainier and Washington Forest Reserves. "Thus," wrote Langille, "I was inducted into government service, got my first lessons in topography, timber estimating, [and] mapping." Langille described Fred Plummer as "an accomplished chorographer, the only one [he had] ever known who could depict the chorography of a mountain from a single station at the base of one side." $" 38$

Although conflict sometimes existed between the Bureau of Foresty and the General Land Office, Pinchot commended the boundary men:

The boundary work was not easy. On horseback or on foot, their grub and blankets on pack horses or on their own backs, the boundary men went where their work led them, trail or no trail. And they moved fast. They had to, for they were working against as competent a body of land thieves as ere the sun shone on. The field men covered an average of about a township a

\footnotetext{
${ }^{38}$ Pinchot, Breaking New Ground,250-251; Robbins, American Forestry, 12; Harold D. Langille, "Mostly Division 'R' Days: Reminiscences of the Stormy, Pioneering Days of the Forest Reserves," Oregon Historical Quarterly, 57, 4 (Portland: Oregon Historical Society, December, 1956), 304. Chorography is defined as: "systematic, detailed analysis of a region or regions."
} 
day. Some of them even declared that during one field season they could do $3,000,000$ acres to the man. ${ }^{39}$

Langille, untrained but enterprising, learned on the job. His chorographic experience was grounded in an objective view of place, one that systematically analyzed the physical landscape through scientific processes, and that is how boundaries, meanings and use would be ascribed to the landscape. When Gannett asked him to make a topographic map report in the Cascade Range from the Columbia River to the south of Mount Hood, he protested that he had neither the equipment nor knowledge to do so. Gannett assured him that a plane table and telescopic alidade would suffice. "I wouldn't have known a telesopic alidade from a perambulator," wrote Langille. "My need for education as an engineer was immediate. It was urgent. So I hurriedly sent three dollars to the nearest bookseller, received a two-volume set of 'Gillespie's Surveying." From Gillespie's Langille learned that a telescopic alidade had a straightedge with a telescopic sight or some means of sighting parallel to the straightedge of the planing table, and armed with the knowledge he became a surveyor.

Within a couple of years Langille became an inspector in the General Land Office. As an inspector, he had authority to hire and fire personnel, and to interpret Reserve law. As part of his job, Langille focused on timber fraud. In the Pacific Northwest, he seized illegal sawmills, and prevented illegal land claims by those seeking timber. He also attempted to educate honest forest reserve users, "to

\footnotetext{
${ }^{39}$ Pinchot, Breaking New Ground, 252.
} 
inform the concerned people of the effect upon their economy and gain their support and goodwill., ${ }^{40}$

Based on the work of boundary men like Plummer and Langille, in his annual report to the U.S. Geological Survey, Gannett reported the Rainier Forest Reserve contained over 20 billion board feet of timber and about 45,000 acres of "fair farming land," much of it too high or exposed for agricultural crop production.

Table 1: Arable Land in southern portion of Mt. Rainier Forest Reserve, $1900^{41}$

\begin{tabular}{|l|l|l|}
\hline Name of Valley & $\begin{array}{l}\text { Acres of } \\
\text { arable } \\
\text { land }\end{array}$ & Description \\
\hline Wind River & 8,000 & $\begin{array}{l}\text { Low and broad, good land, but difficult } \\
\text { to clear }\end{array}$ \\
\hline Little White Salmon & 2,000 & $\begin{array}{l}\text { Same as Wind River, but smaller } \\
\text { timber already partly removed by } \\
\text { logging and for railroad ties }\end{array}$ \\
\hline White Salmon & 2,000 & $\begin{array}{l}\text { Might be made profitable by irrigation, } \\
\text { but with a short season }\end{array}$ \\
\hline $\begin{array}{l}\text { Klickitat (various regions } \\
\text { divided) }\end{array}$ & 14,500 & $\begin{array}{l}\text { Moist bench lands - short season - of } \\
\text { doubtful value; Bench land supporting } \\
\text { a growth of yellow pine and pine grass } \\
\text { - would be fair land under irrigation; } \\
\text { Bottom and bench lands - fair land, } \\
\text { arable of terminal moraines }\end{array}$ \\
\hline Lewis & $\begin{array}{l}\text { A canyon and high altitudes; not of } \\
\text { much use }\end{array}$ \\
\hline
\end{tabular}

The report identified the Cowlitz Valley in the northern portion of the reserve as the most agriculturally significant, with 12,000 acres of potentially good agricultural land. Most of the land was in the Big Bottom Valley, with twenty-five

\footnotetext{
${ }^{40}$ Langille, "Mostly Division "R" Days," 304, 308-309.

${ }^{41}$ Table created based on Department of the Interior, U.S. Geological Survey, "Mount Rainier Forest Reserve, Washington," by Fred G. Plummer, in Annual Report of the U.S. Geological Survey, 1899-1900 (Vancouver, WA: Gifford Pinchot National Forest Headquarters), 91-92.
} 
percent already slashed and partly cleared. The examination showed that the southern portion of the forest held approximately half the potentially arable land. Plummer determined that most of the land in the Klickitat Valley was of doubtful value to farmers, because it required irrigation. The 8,000 acres in the Wind River Valley, although "good land but difficult to clear," had already attracted many settlers as had the valley of the Little White Salmon River. The Wind River Valley also contained a major portion of the forest's timberland. The examiners divided the forest into three main regions based on the markets for lumber export Tacoma/Chehalis, Portland, and North Yakima - determining how much timber existed in each valley, in millions of board feet (mbf) and in acres.

Table 2: Timber Estimates, Portland region, Mt. Rainier Forest Reserve, $1900^{42}$

\begin{tabular}{|l|l|l|l|}
\hline Watershed & Acres & Total stand & Average per acre \\
\hline Lewis & 189,240 & $2,960,005,000$ & 13,295 \\
\hline Washougal & 3,280 & $86,025,000$ & 26,227 \\
\hline Rock Creek & 6,040 & $380,550,000$ & 63,005 \\
\hline Wind River & 122,030 & $3,749,605,000$ & 25,858 \\
\hline Little White Salmon & 66,820 & $302,570,000$ & 4,223 \\
\hline White Salmon & 76,570 & $539,290,000$ & 5,106 \\
\hline Klickitat & 133,810 & $1,868,000$ & 11,075 \\
\hline
\end{tabular}

The Columbia's tributaries in southwestern Washington, the Washougal, Rock Creek and Wind River, held the highest average per acre timber stands in the entire forest. The Wind River Valley, with nearly four billion board feet of timber, also contained more timber than in any other watershed on the Mt Rainier Reserve. Only the White River (2.9 mbf), the Puyallup (1.7 mbf) and the Cowlitz (1.7 mbf)

\footnotetext{
${ }^{42}$ Plummer, "Mt. Rainier," 116-126.
} 
approximated the amount of timber growing on the Wind River, a region that would become hotly contested. ${ }^{43}$

By 1903, the GLO "lent" Langille to the Bureau of Forestry, where he fixed reserve boundaries and directed examinations of proposed withdrawals of forestland - eliminations - for agricultural purposes in Oregon and Washington. Langille later claimed that he grew to believe the avowed purpose of the Roosevelt administration was to retain forestland in government ownership. He recalled that he "almost broke with Forester Pinchot over the matter of eliminating potential and actual agricultural lands in the valleys of rivers discharging from the western slope of the Cascade Range." It is possible, although not clear, that he meant lands in the Wind River Valley. Some lands, such as in the Cowlitz Valley, would not be eliminated from the reserve until much later. In any case, under the Roosevelt administration, Gannett's recommendations went to Gifford Pinchot, the head of the Bureau of Forestry. Pinchot got his forests, and utilitarian conservation became the "primary philosophy" in this "brave new world" of bureaucratic organization. ${ }^{44}$ Between 1903 and 1909, the area within forest reserve boundaries increased from $62,354,965$ acres to $194,505,325$ acres. Pinchot credited both Roosevelt and the boundary men, later writing: "Had the country been under a different kind of President than Theodore Roosevelt, the area of National Forests would have been

\footnotetext{
${ }^{43}$ Plummer, "Mt. Rainier," 111-128.

${ }^{44}$ Miller, Gifford Pinchot and Environmentalism, 138.
} 
far less than it is today, and so it would if our boundary men had been less enterprising, determined, and effective" ${ }^{, 45}$

\section{Opposition to Forest Reserves in Washington State}

The first major opposition to the national forest reserves came from Washington State. In some portions of the West, reserves came about because of grassroots efforts to preserve the forests for public use. However, very little local support existed for reserves in Washington. The Washington State reserves - the Washington, Olympic, and Mt. Rainier - resulted from the Academy Commission's recommendations. On the Olympic Peninsula and in the counties of the western Cascades, sporadic protests against the reserves continued from 1898 through the early twentieth century. Northwesterners argued that the reserves tied up agricultural land, and petitions came in to the Land Office "praying for relief from the hardships wrought on the poor but honest settler" by the reserves ${ }^{46}$ :

The arguments advanced were plausible and at times heart-rending. Homesteaders who had spent the best years of their lives developing fertile farms in the region found their investment was for naught; Clallam and Jefferson Counties had lost most of the taxable land in their counties; schools would close and road bonds, owned by 'widows and aged people in the east,' would be defaulted; farmers already in the area would sell out for lack of markets and in order not to be caught in enlargement of the reserves. $^{47}$

\footnotetext{
${ }^{45}$ Langille, "Mostly Division 'R' Days," 310-311; Pinchot, Breaking New Ground, 251 -252.

${ }^{46}$ Rakestraw, "Uncle Sam's Reserves," 126.

${ }^{47}$ Rakestraw, "Uncle Sam's Reserves," 130.
} 
The U.S. Geological Survey examined the Olympic Reserve, and despite Henry Gannett's opposition, the Department of Interior acceded to pressure, and eliminated 264,960 acres in April, 1900.

Agitation continued successfully in the Puget Sound area. Washington Senator Addison G. Foster and then-Representative Wesley Jones and Francis Cushman pushed for further eliminations from the Olympic Reserve. By July 1901 agricultural withdrawals had reduced the Olympic Reserve by nearly half a million acres. According to Lawrence Rakestraw, two-thirds of the "agricultural" land in the eliminated portions went to logging companies. A similar series of events took place on the Washington Forest Reserve. Alleged settlers sent in petitions to Congress from Whatcom and Skagit Counties, and the Land Office and Geological Surveys made a series of examinations. Again despite disagreement, "Pressure was so great that the Forestry Bureau decided to sacrifice the timber land for the sake of better public relations. ${ }^{, 48}$

In the southern part of Washington State, where the Rainier Reserve encompassed portions of Clark, Skamania, and Cowlitz counties, fierce opposition came when the boundary report proposed additions to the reserve. First to protest were railroad promoters. The Portland, Vancouver and Yakima Company (P.V. \& Y) proposed a railroad through lands that had become part of the Rainier Reserve. The railroad planned to serve the region between Yakima and Vancouver along the north side of the Columbia River, running north from Vancouver through Yacolt,

\footnotetext{
${ }^{48}$ Rakestraw, “Uncle Sam's Reserves,” 134-135, 144.
} 
and into the Lewis River watershed, then south of Mt. Adams, down to the Klickitat River, through Goldendale, and on to eastern Washington. Not only would the line serve as a transcontinental link on the north side of the Columbia, it would also make available the timber and mineral resources around Mt. Adams and Mt. St. Helens. By 1898 , the railroad extended as far to the east as Battle Ground where timber operations were already underway.

Enlargement of the Rainier Reserve interfered with P.V. \& Y plans. The company president claimed that the proposed reserve addition would close half the mills in Portland, destroy Clark County's prosperity, and disappoint the 150 settlers waiting for railroad service. The Portland Chamber of Commerce, the Vancouver Commercial Club, the Republican City and County General Committee, and the Washington State Commissioner of Public Lands joined the railroad's protest. In 1901, as the North Bank addition to the Northern Pacific began along the Columbia River, the P.V. \& Y charter disappeared. By 1907, the North Bank Railroad provided service through the Columbia River Gorge.

Similar protests came in from Cowlitz County. Residents claimed the reserve took up two-thirds of the county, removed the potential tax base, cut off county roads and trails, and removed valuable agricultural and stock grazing lands. After examining the lands, superintendent of Washington reserves, D.B. Sheller, decided the chief dissatisfaction was "the removal of land from the county tax rolls and the danger of curtailing logging." When a fire in 1902 destroyed much of the valuable timber in southwest Washington, protests over reserve additions died 
down, although final reserve boundaries eliminated the burned over lands in 1907. After the 1902 fire, residents of Yale, Amboy, and Ariel obtained elimination of agricultural lands in the general area. Congress supported their agricultural argument since the 1902 fire killed much of the timber in the region. ${ }^{49}$

Skamania County residents also issued a strong outcry against the reserve by filing petitions to eliminate agricultural lands and writing scathing editorials to the local papers. Lumber interests opposed the expansion more subversively. Throughout the West, "dummy entrymen" filed claims on reserved lands and entreprenurial homesteaders speculated in timber. Skamania County was no exception. The 1897 Organic Act had restored lands reserved by Cleveland to the Public Domain until March 1, 1898, and a flurry of homestead entries ensued in the Upper Wind River Valley.

\footnotetext{
${ }^{49}$ Rakestraw, "Uncle Sam's Reserves," 146-151.
} 
Figure 6: An Abandoned Homestead. Photo courtesy Gifford Pinchot National Forest

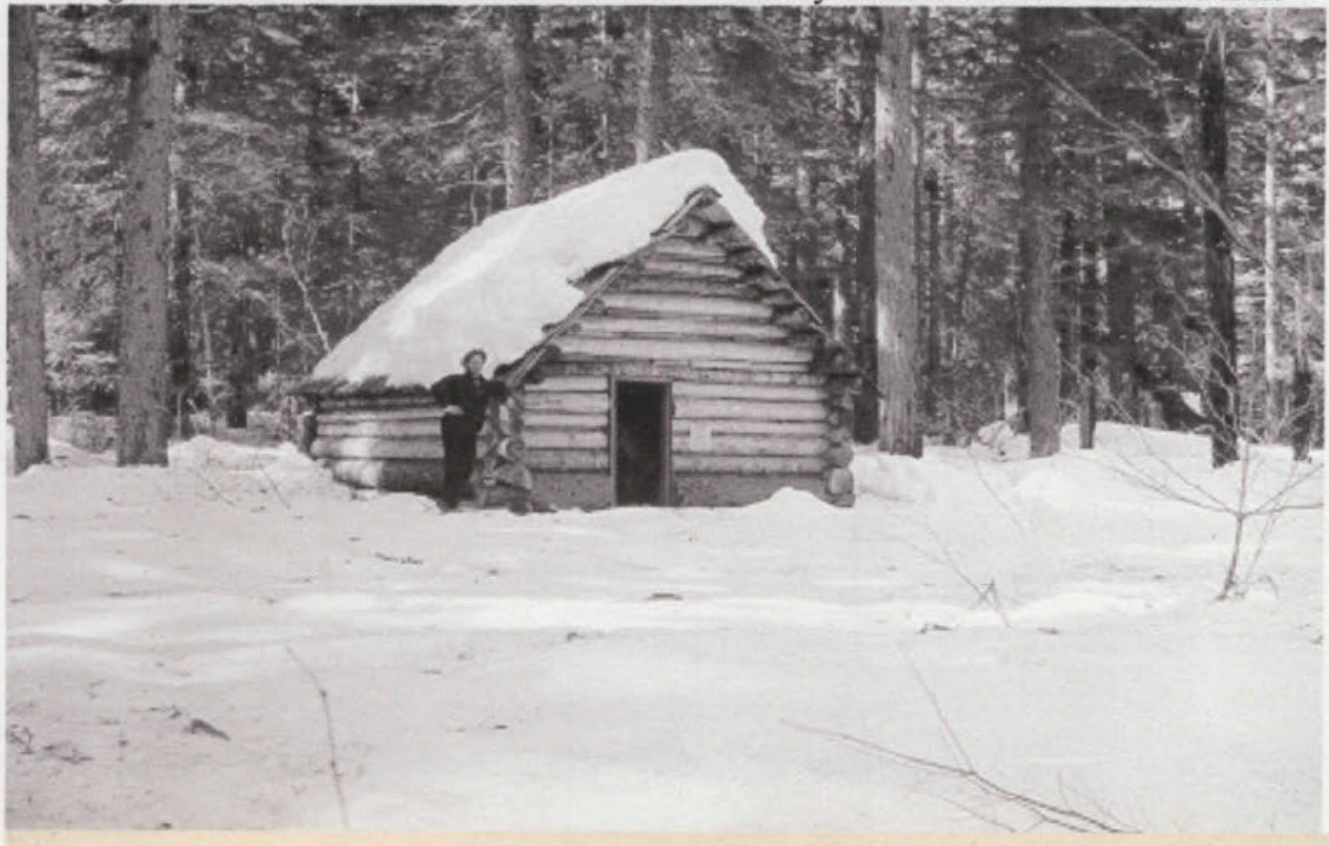

U. S. DEPARTMENT OF AGRICULTURE FOREST SERVICE

\begin{tabular}{|l|l|l|}
\hline PRESBENTKO BY COPYRIOHT. & REPAODUCED. \\
\hline
\end{tabular}

Skamania Co., Washingtor March 18, 1911. An abandoned homestead. commuted after a pretence of residenceint. No clearing or cultivation - Sold to Wind River Lumber $e_{0}$ and sowent by for the larger part of cultivable land in the Wrind River lalley. sprecrs

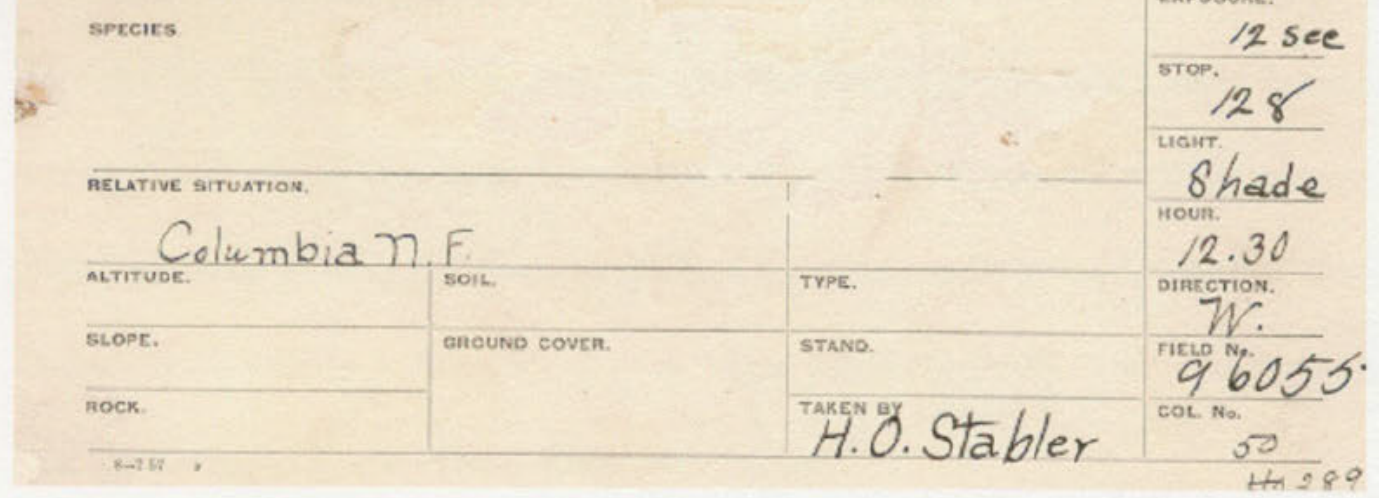


Between September 1897 and May 1898, legitimate and less legitimate homesteaders claimed 3,040 acres in the Upper Wind River Valley. In September 1897, for example, George Warren and Charles Russell each filed 160-acre claims. By 1900 , Charles Russell had transferred 160 acres to F.W. Kale, who within a week sold it to the Wind River Lumber Company. George Warren sold his 160 acres directly to the Wind River Lumber Company a year after patenting in April 1902. October and November 1897 brought a rush of homestead entries to the valley. On October 7, 1897, L.T. Smith filed two 80-acre claims, one in section 23, the other in section 26. Three weeks later, Gianini Pietro became his neighbor, filing a 120 -acre claim in section 26 and a forty acre claim in section 23 . Smith's claims went to the Wind River Lumber Company's subsidiary, the Skamania Boom Company in 1900. Gianini's claims went directly to the Wind River Lumber Company three months after patenting, in March 1904. S.S. Dill and G.A. Agosti followed the same pattern, with some land listed as sold to the Storey-Keeler Lumber Company (purchased in 1902 by the Wind River Lumber Company) even before patenting. In December, Martha and William Hollis filed 80-acre claims in sections 10,15 , and 16, selling them to the Storey-Keeler and Wind River Lumber Companies by 1902, the same year that the Wind River Lumber Company along with Skamania County residents, petitioned for elimination of lands from the forest reserve in Township 4, Ranges 4-9 [See Table 3 and Figure 8]. They claimed these lands were agricultural. The petition was denied. ${ }^{50}$

\footnotetext{
${ }^{50}$ Rakestraw, "Uncle Sam's Reserves," 152; "History of Land in the Wind River Valley," File No.
} 
Table 3: Assessed value, land in Township 4, 1902 petition $^{51}$

\begin{tabular}{|c|c|c|}
\hline Description of land & $\begin{array}{c}\text { entry/patent/transf } \\
\text { er/price }\end{array}$ & 1902 classification \\
\hline T.4 north, R. 6 east & $\begin{array}{c}1902 \text { - county } \\
\text { assessor }-\$ 57,600\end{array}$ & $\begin{array}{l}1902 \text { petition - about half } \\
\text { good timber. All good } \\
\text { grazing land. About } 1 / 4 \\
\text { good agricultural land }\end{array}$ \\
\hline T. 4 north, R. 7 east & $\begin{array}{l}1902 \text { - county } \\
\text { assessor - } \\
\$ 118,560\end{array}$ & $\begin{array}{l}1902 \text { petition - good timber, } \\
\text { but would also make fine } \\
\text { agricultural land when the } \\
\text { timber is removed - } \\
\text { comparatively level and is } \\
\text { the bets part of the Wind } \\
\text { River Basin }\end{array}$ \\
\hline $\begin{array}{l}\text { T. } 4 \text { north, R. } 7 \text { 1/2 } \\
\text { east }\end{array}$ & $\begin{array}{l}1902 \text { - county } \\
\text { assessor - } \\
\$ 5,400\end{array}$ & $\begin{array}{l}1902 \text { petition - a fractional } \\
\text { township one and one-eighth } \\
\text { miles wide - a mountain of no } \\
\text { particular value for timber } \\
\text { or any other purpose except } \\
\text { grazing }\end{array}$ \\
\hline T. 4 north, R. 8 east & $\begin{array}{l}1902 \text { - county } \\
\text { assessor - } \\
\$ 28,800\end{array}$ & $\begin{array}{l}1902 \text { petition - contains } \\
\text { scarcely any timber and is } \\
\text { mainly agricultural land, } \\
\text { contains fine meadows, an } \\
\text { immense huckleberry patch } \\
\text { and only poor timber }\end{array}$ \\
\hline T. 4 north, R. 9 east & $\begin{array}{l}1902 \text { - county } \\
\text { assessor - } \\
\$ 128,000\end{array}$ & $\begin{array}{l}1902 \text { petition - brushland, no } \\
\text { value for timber, but great } \\
\text { value for agriculture - } \\
\text { contains the "fertile valley" } \\
\text { of the Little White Salmon }\end{array}$ \\
\hline \begin{tabular}{|l} 
T. 4 N., R. $7 \mathrm{E}$ \\
Sec. 21 - 120 acres \\
Sec. 22 - 40 acres
\end{tabular} & $\begin{array}{c}\text { entry-11-6-97 } \\
\text { patent-12-1700 } \\
\text { transfer-5-25-00 to } \\
\text { WRLC }\end{array}$ & $\begin{array}{l}1902 \text { petition - good timber, } \\
\text { but would also make fine } \\
\text { agricultural land when the } \\
\text { timber is removed - } \\
\text { comparatively level and is } \\
\text { the best part of the Wind } \\
\text { River Basin } \\
\end{array}$ \\
\hline
\end{tabular}

2700-1 (Vancouver, WA: Gifford Pinchot National Forest Headquarters).

${ }^{51}$ History of Land in the WRValley, File \# 2700-1. 


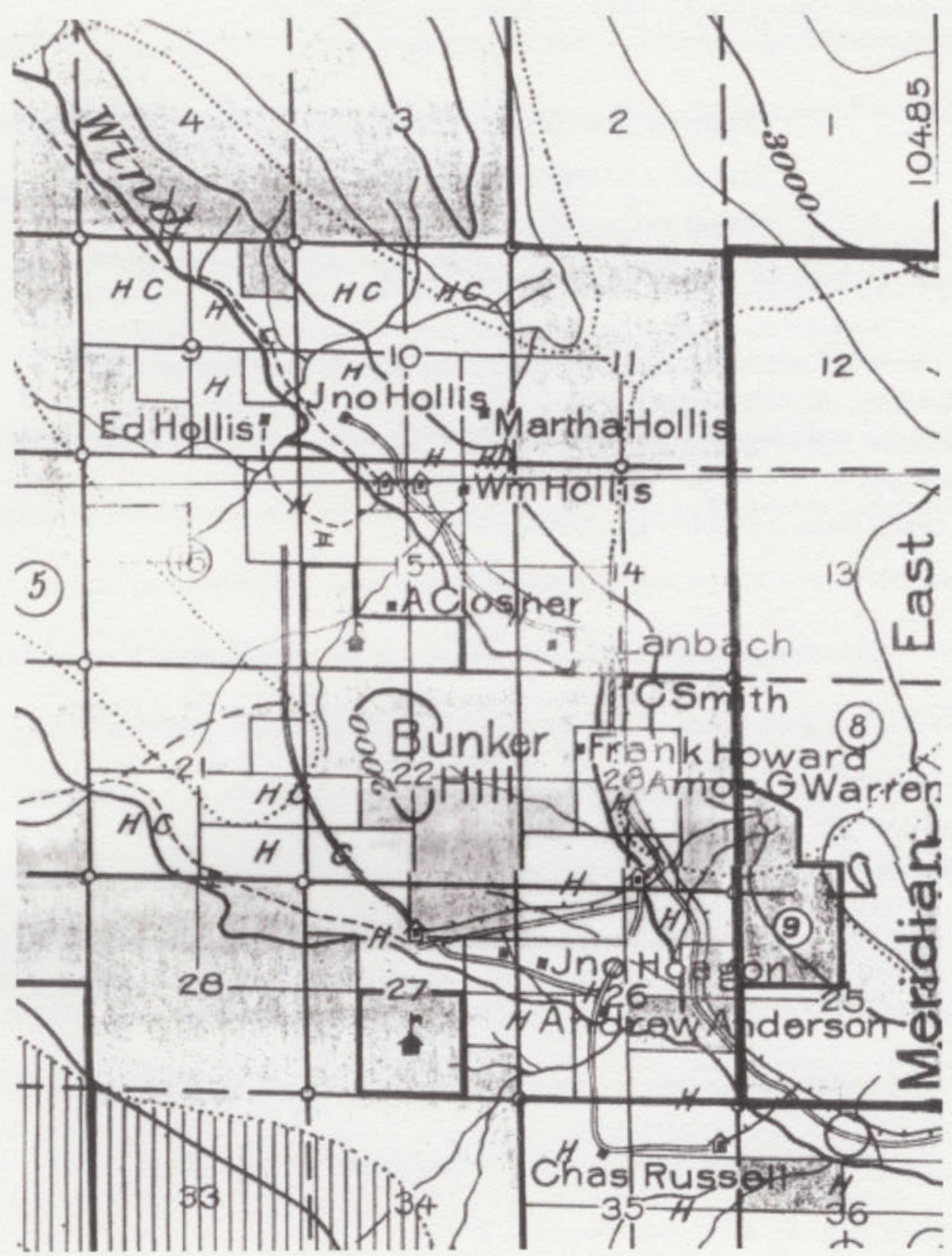

Figure 7: 1908 map showing land claims within Township 4 N., Range 7 E., Wind River Valley. Courtesy Gifford Pinchot National Forest. 
By the end of the nineteenth century, government gained a stronghold through science, via land holding, surveys, and sales. Scientific knowledge became an active determinant in the outcome of resource conflict. In the case of forests, claims Thomas Cox:

Realities came to replace egalitarian concepts as the primary factor shaping forest policy. After the turn of the century, contending interests, battling for implementation of mutually exclusive policies, found it increasingly necessary to cast their arguments in rational, scientific terms. ${ }^{, 52}$

The realities that Cox refers to were scientific, political, and economic. From the seventeenth through the nineteenth centuries, three main assumptions underscored the American perception of resources - they were unclaimed, inexhaustible, and should be used immediately. By the 1890 s, as citizens and legislators began to pay attention to resource depletion, railroad monopolies, and public land theft, conflict ensued over the role of government and the rights of individuals. The government's agricultural ethic and the goal of public land policy to put unused lands into private hands coalesced to create a complex mix of issues during the Progressive era, and many argued that government should regulate social behavior by controlling rampant corporate abuse - of people as well as resources.

For Gifford Pinchot, Progressivism meant systematic regulation of resources, the source of wealth for the few at the expense of the many. Efficient management would be the key to equity. To Pinchot and others, conservation became a struggle for political liberty that could be achieved through rational

\footnotetext{
${ }^{52}$ Cox, Changing Forests, 152.
} 
scientific means with technological decisions made through a central authority. According to Harold Pinkett, Pinchot was "perhaps the only one who knew the road on which the country must march out of the forest wilderness of neglect and destruction., ${ }^{, 3}$ Whether marching out of neglect and destruction is what Pinchot did remains questionable, and certainly many others played significant roles. However, Pinchot's ideas regarding regulated resource use formed the core of forest administration throughout most of the twentieth century. Thus, his perspective and vision is a significant part of forest history. Management of forests would become part of a larger struggle over public lands underscored by issues of private versus public use. Pinchot's promoted a vision of efficiency as a means to equity that would ironically become the route for corporate concentration of resources. $^{54}$

Management of the forest reserves under the General Land Office in conjunction with the specialized functions of the Geological Survey and the Bureau of Forestry, in addition to multitudinous land laws, created a hodgepodge of mismanagement, abuse, and confusion. Some serious and perhaps justified prejudices existed toward the Land Office. Causes for abuse ranged from blatantly ignoring fraud to underfunding and understaffing. Regardless, one thing is clear, rampant abuse benefited corporations more than individuals. The Land Office managed, or from Pinchot's perspective, mismanaged, the timberlands that would

\footnotetext{
${ }^{53}$ Pinkett, Gifford Pinchot, 14.

${ }^{54}$ For an in-depth discussion of the relationship between efficiency and equity, see Clayton R. Koppes, "Efficiency/Equity/Esthetics: Towards a Reinterpretation of American Conservation" Environmental Review 11, 2 (Summer 1987), 127-146.
} 
by 1905 become "his" national forests. According to Pinchot, abuse contributed to inefficient use of forest resources, including water, minerals, and timber. And technical efficiency equaled good forest management. As residents of Skamania County and those with economic interests in the region opposed forest reserves, the national conservation movement gained sway, imposing a new physical and social landscape on Skamania County.

Modifications to the Wind River through blasting rocks and building splash dams, and the establishment of logging camps would soon mark the beginning of another major shift in the forest and community ecosystem of the Wind River Valley. Access to public domain timber facilitated larger investments by lumber companies, and the system of forest administration implemented at the turn of the century eventually allowed the Wind River Lumber Company to harvest millions of board feet of timber from both private and public lands. As logging became an integral part of the economy, the lumber company provided jobs both for local residents and transient forest workers, establishing the roots of a lasting timber culture.

While men like Langille and Plummer surveyed the land, imposing a scientific theoretical structure on the landscape, others engaged physically with place, logging, lumbering, and homesteading. Early logging impacted the forest ecosystem, and public land laws and national legislation at the beginning of the new century re-shaped relations between the community and the forest. The structural changes taking place on the north shore and the on-the-ground activity of 
community members would soon reshape the social landscape. In addition, while the GLO examined lands and added to the reserves, the Bureau of Forestry began implementing long-range plans for a system of "practical" forestry. The new forestry practices would quickly redefine relations between communities, the government, and with the forests of southern Skamania County. 


\section{CHAPTER FOUR: TREE FARMING IN THE AGRICULTURAL EMPIRE Protest, Fire, and Public Improvement}

Big timber, lush meadows, rushing waterways, and abundant wildlife comprised the lands of the Wind River Valley at the turn of the century. For many in Skamania County, the valley constituted one of the county's main routes to prosperity, a seeming goldmine of timber and agricultural potential. The Wind River Valley played a significant role in the development of southern Skamania County, but not in the way community members had hoped. Attempts to gain access to the timber and bottomlands along the Wind created a distinctively cooperative community and an economic development movement in the county. Conflict over the lands of the Wind River Valley drew people together, individually and institutionally. At the same time, it created long term divisions between the federal government and the people. An historical view of events in the valley from the turn of the century until 1913, as people struggled for control of the forest, its resources, and meanings, demonstrates how place is shaped, and its role in shaping community. As Nicholas Entrikin explains, social and economic forces combine to shape places and in turn are shaped by place. Within a specific locale, the perspectives and experiences of individual actors produce unique political and social outcomes because they play out under varying circumstances. ${ }^{1}$ In the case of the Wind River Valley, use of the material landscape had several possibilities. The

\footnotetext{
'Entrikin, Betweenness of Place, 21.
} 
ways in which the valley's resources were accessed, and by whom, are part of a broader political and social narrative.

The struggle for the forest and its resources began in the context of regional development. Like many isolated western communities at the turn of the century, Skamania County residents wanted connections to the outside world. To this end, residents attempted to promote the communities along the Columbia River's north bank, especially Stevenson and Carson. The river provided an important connection to the region, but the county also sought state road funding to tie county communities together. At an informal meeting in Stevenson in 1902, local businessmen formed the Skamania County Road Improvement Association. Skamania County Pioneer editor, Milton Harlan, acted as meeting chair and the board raised $\$ 120$ for a wagon road from Stevenson to the top of the high, rocky ridge leading to the Wind River. The group hoped that the road would begin to make "Skamania one of the most important counties of Southern Washington." But Harlan lamented that a more broadly based organization had not been formed, one that would be able to address opening the forest reserve. A few weeks later the name of the road organization changed to the Skamania County Board of Public Improvement. The objectives of the new organization, headed by Milton Harlan and businessman William L. Gray, were "to construct public roads, open up the agricultural portions of the forest reserve, organize a county fair, or dispose of any other question of public interest that may arise." Eligibility to serve on the board depended on property ownership. Women were barred, the unpaid officers 
served for one year, and the board held regular meetings in Stevenson, the first Thursday of each month. The Skamania County Pioneer deemed the Public Improvement Board "The most auspicious beginning for the rapid settlement and development of Skamania County." In keeping with the sense of potential prosperity and competition for railroads and services throughout developing western communities, some in the community of Carson questioned the Board's motivations, claiming it was a Stevenson association "trying to boss or lead its neighbors."

In February 1902, within a few weeks of the board's formation, Forest Superintendent D.B. Sheller visited Skamania County. The superintendent stayed for three days, inspecting local sawmills in the White Salmon and Wind River Valleys. It is significant that a number of sawmills, both unincorporated and incorporated, operated in the county, considering that boosters would soon push even harder to obtain land they deemed agricultural.

2 "Skamania County Road Improvement Association Formed," Pioneer, 16 January 1902; Pioneer, 20 February 1902. 
Table 4: Incorporated Lumbering Companies or Sawmills, 1850-1921 ${ }^{3}$

\begin{tabular}{|c|c|}
\hline Date of Incorporation & Company Name \\
\hline August 27, 1895 & Spirit Lake Lumber \& Improvement Co. \\
\hline March 8, 1894 & Washougal Land \& Logging Co. \\
\hline December 21,1898 & Fir Tree Flum Co. \\
\hline January 6,1900 & Rock Creek Boom Co. \\
\hline June 24,1902 & Washington Lumber Co. \\
\hline December 19,1902 & Chenowith Boom \& Lumber \\
\hline February 7,1903 & Skamania Boom Co. \\
\hline October 26,1903 & Skamania Lumber Co. \\
\hline November 22,1906 & L.P. McCroskey \& Sons Lbr Co. \\
\hline January 16,1907 & Diamond "L" Lumber Co. \\
\hline September 11,1907 & White Salmon Boom \& Improvement Co. \\
\hline March 20, 1909 & Four Lakes Lumber Co. \\
\hline June 6,1910 & Oregon-Washington Logging Co. \\
\hline April 1, 1911 & Oregon Lumber Co. \\
\hline June 20, 1912 & Washington Logging \& Lumber Co. \\
\hline November 25,1912 & J.K. Lumber Co. \\
\hline July 13,1916 & Rock Creek Lumber Co. \\
\hline August 6,1917 & Little White Salmon Boom Co. \\
\hline October 17,1919 & Wahclella Lumber Co. \\
\hline March 3, 1921 & Crescent Lumber Co. \\
\hline
\end{tabular}

At least five sawmills or lumber companies had incorporated in the county by 1902, although some small mills remained unincorporated. For example, the Colter Mill in Township 3, at the edge of the reserve between the Wind and Little White Salmon Rivers was not among incorporated mills or lumber companies, but it is mentioned more than once in the historical literature, and a number of small mills had operated along the Columbia River since the 1850 s. $^{4}$ By 1906 there would be ten incorporated companies, with another eleven incorporating by 1921 . When the

\footnotetext{
${ }^{3}$ Skamania County Auditor's Office files, "Incorporated Logging Companies and Lumber Mills, Skamania County, 1850-1920."

4 "Elias Wigal Diaries," Draft transcript, Gifford Pinchot National Forest Heritage Program Headquarters, Trout Lake, Washington (January 2004), 52.
} 
Board claimed the reserve was injurious to the county because of the agricultural potential of certain lands, Sheller responded by outlining the procedure for agricultural land elimination. First, a report must be submitted, with truthful land descriptions signed by actual settlers within and outside the reserve. County officers also needed to testify that the reserve impacted the county's available taxable land. In addition, county officials had to report county operating expenses affected by the withdrawal of lands for public use. ${ }^{5}$

On February 22, 1902, J.W. Hill of Chenowith joined the petition for elimination of agricultural lands from the reserve in Township 4, Range 4-9, that had been requested by the Wind River Lumber Company. ${ }^{6}$ Hill's petition went to every post office in the county, and residents from Collins, Home Valley, Stevenson, Cape Horn, and Carson backed him. Hill wrote both to President Roosevelt and Binger Hermann, U.S. Land Commissioner, claiming that citizens generally agreed that the reserve included much agricultural land. It was "a hard proposition to take from a few to give to the many. . for a general public benefit." Without even a survey, the government had closed eighty percent of the county to settlement. In a letter to the Skamania County Pioneer that reflected the significant spatial relationship between forest and river, Hill warned locals to pay attention to their plight, asking: "How detrimental to us is the forest reserve, especially along this great thoroughfare of the Columbia river?" Hill argued that there should have

\footnotetext{
${ }^{5}$ Ibid; Auditor's Office files, "Incorporated Logging Companies."

6"Interested in Roads," Pioneer, 13 February 1902; Lawrence Rakestraw, "A History of Forest Conservation in the Pacific Northwest, 1891-1913," (Ph.D. Diss., University of Washington, 1955), 152.
} 
been twelve miles left along the south boundary instead of six. The boundary should be moved. Then he came to the main impact of the forest reserve: how can we support a county organization "on such limited territory?"”

The Board of Public Improvement contended the county needed two things: a transportation infrastructure, and access to forestlands. As they pushed for the wagon road, the board set out to open the reserve. Local leaders, including company owner J.O. Keeler and company treasurer Clark Thompson of the StoreyKeeler Lumber Company, attended board meetings. By April, a forest reserve committee had written a petition for the Secretary of Interior, including three exhibits, each demonstrating the need for county improvement funds. Using arguments common all over the West, the board claimed that not enough land remained to fund a county organization, build roads, bridges or a county courthouse. The petition identified Township 4 as more useful for agriculture than timber, with an assessed value of $\$ 338,360.00$. [see Table 3]

Residents and businessmen recognized that county development depended on taxes and transportation, and with a decreased land base people became defensive. Skamania County Pioneer editor Harlan attempted to instill hope into the community. The Northern Pacific planned a connection by 1904, which would connect north bank Columbia Gorge communities to Vancouver. When the railroad arrived the Storey-Keeler Lumber Company planned to move its mills to

\footnotetext{
7 "Forest Reserve: Interesting Facts Concerning Its Features and Extent," Pioneer, 6 March 1902;

"The Forest Reserve," Pioneer, 2 January 1902.
} 
the north side of the river. ${ }^{8}$ Storey-Keeler, according to the Pioneer publisher, had done more to open the county to settlement than anyone else. In 1902, with Wind River residents, Storey-Keeler financed a dam requiring more than a million board feet of timber to build. The splash dam allowed the lumber company to get the timber out of the forest. ${ }^{9}$

Using the rhetoric of anti-corporate Progressivism, Harlan wrote an editorial supporting the reserves. It was timber speculators and cattle barons who prompted their creation, and residents should denounce them, not the government. The purpose underlying the reserves, wrote Harlan, was "a righteous one," for the exploitation of Midwest forests had led to denuding timberlands, waste for profit, and ultimately huge forest fires. The problem was land fraud, pure and simple. Railroads and timber magnates took the land "out of the reach of the settler," and "out of the reach of the poor man who needed it for a home and to whom the government intended it to go." Timber syndicates in Oregon had already been formed, wrote Harlan, and the reserves would remedy "this evil," but:

... The chief injury at present noticeable is that much good agricultural land is included in the reserves, which, of course was unavoidable, considering the haste necessary in apportioning them and the fact that they were unsurveyed.

\footnotetext{
${ }^{8}$ Storey-Keeler never did move its mill to the north side of the river.

9 "The Big Dam," Pioneer, 16 January 1902.
} 
In an effort to gain institutional support, Harlan proclaimed, "The government is all right and will open every acre of land that may be needed by the actual settler when the proper showing is made in a proper way." 10

The "proper way" would be to produce concrete evidence that the desired lands were agricultural. Residents continued to argue for the removal of lands from the reserve, and they set out to prove the agricultural usefulness of high elevation lands. P.S.C. Wills, farmer, promoter, and a leader of the Board of Public Improvement, took to the hills in May 1902 to conduct his own agricultural experiment. Three miles above Stevenson, in a burned over area at an elevation of 3,000 feet, the innovative agriculturist, trusty axe in hand, planted turnip seeds. The seeds sprouted and grew quickly, so that within sixty days he not only had sixteen inch turnips from the burned over area, but also fourteen inch turnips from a snow covered area further up the mountain side. The farmer's success prompted an agricultural booster at the Pioneer to declare: "times will prove that the higher elevations are the best farming lands, and that not only vegetables, but fruit, will do better than on the lands near the level of the river." Unfortunately for the agricultural hopefuls, you cannot mill lumber from turnips, and eastern capitalists were unwilling to invest in fields of root vegetables. Timber, however, was a different story. The local paper reported that from one to a dozen men arrived in Stevenson daily looking for homesteads and hoping the forest reserve would be opened. At the same time, Skamania County lumbering prospered. Meanwhile,

\footnotetext{
10 "The Forest Reserve," Pioneer.
} 
the Bureau of Forestry in Washington D.C. geared up for more active management in the western reserves. ${ }^{11}$

The Forestry Bureau would get its wish. In September 1902 a major fire took place that further justified federal forest management. Among the problems facing the reserves, fire proved most immediate. From 1898 to 1905 the General Land Office (GLO) managed the reserves. For the first two years, GLO management occurred without any appropriations for protection or administration, despite fire prevention as a number one assignment. In 1901, Interior Secretary Ethan Allen Hitchcock issued an outline on reserve supervision. "The first duty of forest officers," he wrote, "is to protect the forest against fires." Hitchcock also created a Forestry Division in the General Land Office to administer the reserves, and Filibert Roth, Ethan T. Allen, and other advisers from the Bureau of Forestry transferred to the GLO. In 1902, the GLO published the Forest Reserve Manual and issued a circular describing how to conduct patrols. ${ }^{12}$

That year, disaster struck Oregon and Washington. In late August and early September 1902, huge fires, later collectively called the Yacolt Burn, raged on both sides of the Columbia. Residents of Skamania, Lewis, and Clark counties shook with fear. The Pioneer reported: "At night the skies are aglow with the saffroncolored hues made by flames afar, and at times the smoke is so dense as to obscure the nearest mountains whose base lies at our feet." Fire circled the town of

\footnotetext{
11 "Value of the Reserve," Pioneer, 24 July 1902.

${ }^{12}$ Stephen J. Pyne, Year of the Fires: The Story of the Great Fires of 1910 (New York: Viking Press, 2001), 229-230.
} 
Stevenson and raged through portions of the Wind River Valley. It was "terrible," said one Stevenson resident:

... Many people were burned to death. Many trees fell across the road and blocked the way out. We were hemmed in and couldn't get out. We sat in our yard with our grips packed from Monday night until Saturday morning, expecting every day to be burned to death. We lay on the ground most of the time and we kept the babies there all of the time, because the only air one could breathe was next to the ground. The fire went in a semi-circle around this town (Stevenson) or we would all have died. ${ }^{13}$

Heavy winds spread the fire, destroying homes, property, and trees. Damage in Washington State amounted to nearly $\$ 9$ million, and flames devoured an estimated $\$ 50,000$ in timber, bridges and culverts owned by the Wind River Lumber Company.

The Yacolt burn produced general agreement about the need for a fire protection system. Editor Harlan interviewed J.A. Buckley, who had inspected the burned-over region. The inspector described timber damage from Wind River to the Lewis River in Clark County, a strip of territory about ten miles back from the river and "from ten to thirteen miles wide all the way." It burned timber in eight or nine townships, including much of the area the Skamania Board of Public Improvement wanted taken out of the reserve. Some, like J.P. Gillette, valued the burned over lands more for their agricultural value than for timber. Gillette decided that rather than sell an eighty-acre plot, now that it was cleared by fire he would sow it in grass. He expected a big annual return in hay. Although the fire provided

\footnotetext{
${ }^{13}$ James G. Harris, "Skamania County" Told By the Pioneers (U.S. Works Progress Administration. Vol. 3, Washington Pioneer Project. Printed under WPA Sponsored Federal Project No. 5841, 1938), 74.
} 
justification for elimination of lands from the reserves in some other localities such as the Lewis River region, agricultural arguments did not work in southern Skamania where big timber dominated the landscape. Buckley's conclusion reflected the role played by the Yacolt Burn in retaining Township 4 lands in the reserve: "I think the more timber that the government will preserve," he told Harlan, "the longer it [the reserve] will last." Although the fire destroyed millions of dollars in timber, a significant amount remained harvestable, and the burned over landscape later provided other possibilities. ${ }^{14}$

In 1901, the Skamania Boom Company obtained a charter from the State of Washington to artificially flood the Wind and its tributaries, Trout and Panther creeks. With these "improvements" on the river, it was possible to move logs to the Columbia River and thence to the Wind River Lumber Company's mill at Cascade Locks. Modifications included building splash dams on Wind River, Trout, and Panther creeks, building a boom - a chain, cable, or series of connected floating timbers serving to confine floating timbers - at the Wind River's mouth, and blasting rocks through restrictive areas. When logs jammed, men blasted the rocks with dynamite if they could not free the timber with a saw. They also blasted rocks along the river to prevent the logs from becoming "beat up." The lumber company hired men to "'sack the banks,' the treacherous task of hiking along the banks of the river and pushing the stranded logs back into the river with a peavey, a

${ }^{14}$ Pioneer 11, 18 September, 2 October 1902. 
tool with a heavy wooden handle that has a metal spike point and free swinging hook at one end."15

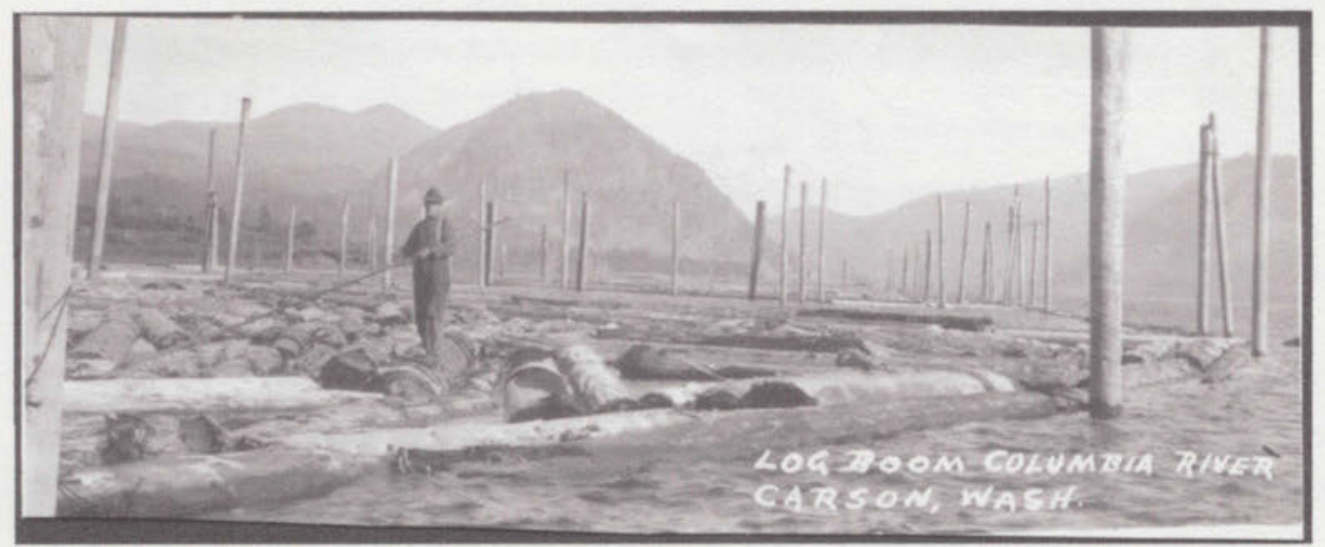

Figure 8: Log Boom, Columbia River. Photo courtesy Gifford Pinchot National Forest

Andrew Millar Lindsay, later superintendent for the Wind River Lumber Company's logging camps, built the first splash dam on Trout Creek in Township $4 \mathrm{~N}$., Range 7E where the Wind River Work Center ${ }^{16}$ is today. At that time, before the Yacolt Burn, "deep, deep forest ... all virgin timber" surrounded the area. The timber was late-succession hemlock and fir in a diverse vegetative ecosystem with numerous animal species and a wide range of fish in the river, including salmon. The logging company established Camp Three at the splash dam on Trout Creek, where the Lindsay family lived that year. For many in the region, the woods were an integral part of family and childhood experience, and Lindsay's daughter Phoebe remembered the dam building:

\footnotetext{
${ }^{15}$ Jamie Tolfree, "History of the Wind River Lumber Company in the Upper Wind River Valley, Part 1, Skamania County Heritage, 13, No. 3, (December 1984), 5-6.

${ }^{16}$ The former site of the Wind River Ranger Station is now used as a work station by the Forest Service.
} 
Made out of logs. Great big logs ... My dad's brother was an expert with a broadax and he squared up the big logs, and Dad went out through the timber and spotted the logs that he wanted for the base of that dam and they brought them in with the donkey [a steam donkey] ... and Uncle Bruce hewed those logs, squared them up. And after they were squared, about four of us kids could walk on them side by side. They were that big ... They looked just like they'd been planed when he got through with them ...

Why, us kids used to ride on the logs when they pulled them across that flat up there with the donkeys. Until our dad caught us. ${ }^{17}$

Figure 9: Splash Dam on Wind River. Photo courtesy Gifford Pinchot National Forest

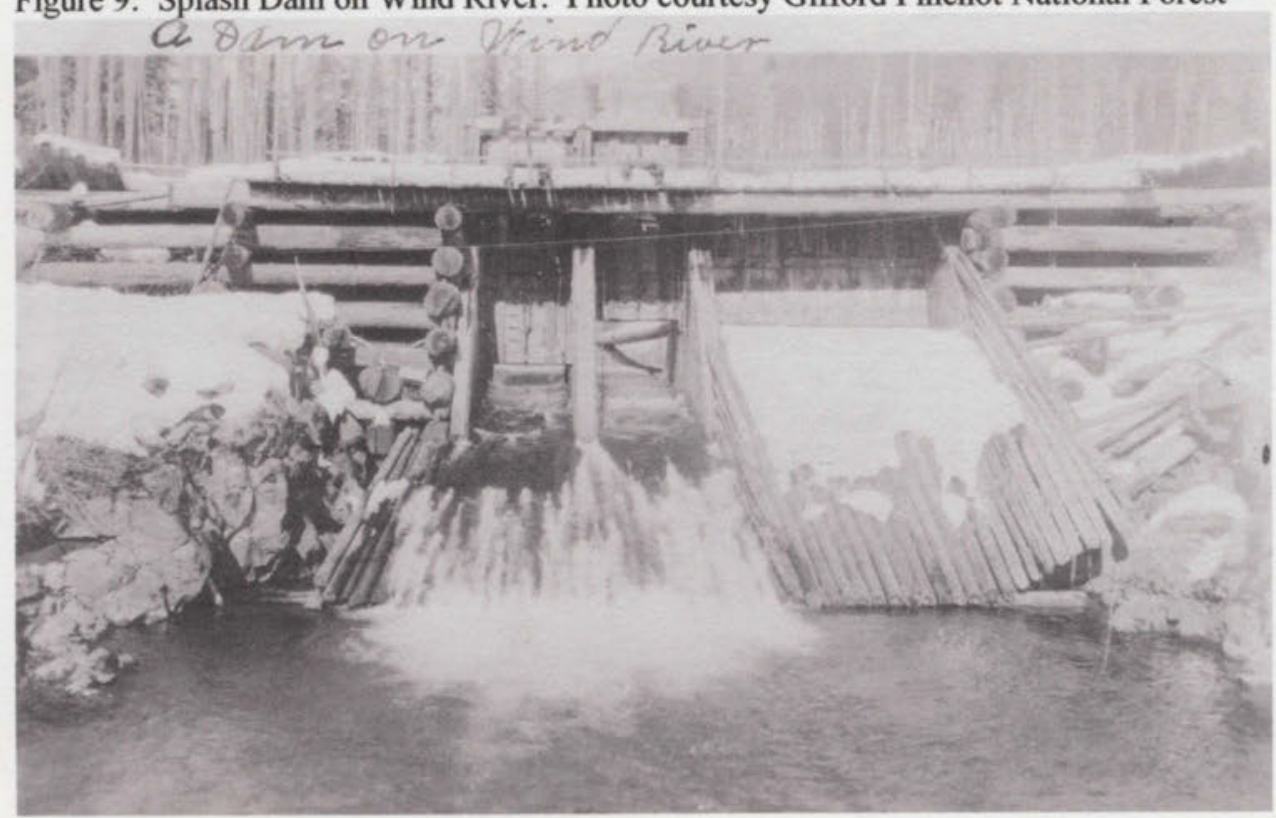

In the early logging days along the Wind River, men cut timber with twoman crosscut saws known as misery whips. The name stemmed from the hard, dangerous work entailed in lumbering. They bucked the logs into lengths and skidded them through the valley to log ponds on Trout Creek and Wind River using a dolly - a "two-wheeled log cart that could haul one or several logs at a time,

\footnotetext{
${ }^{17}$ Phoebe Yeo, "An Interview with Tom \& Phoebe Yeo," Interview by Ivan Donaldson, March 16, 1981, Oral History Collection, Skamania County Historical Society, Columbia Gorge Interpretive Center, 8.
} 
depending on their size"18 - and a team of horses. A "grease monkey," usually a teenage boy, ran ahead with a bucket and swab to lubricate the log skid road as the horses dragged two or three huge trees along it. Loggers timed the release of water at splash dams along the creeks to keep the logs moving to the Columbia where a boom, "in this situation ... a string of logs" stopped them from floating uncontrollably into the big river. From there, men separated the logs, mainly old growth fir and hemlock, and rafted them to the mill. ${ }^{19}$

Figure 10: Log Drive on Wind River. Photo courtesy Gifford Pinchot National Forest

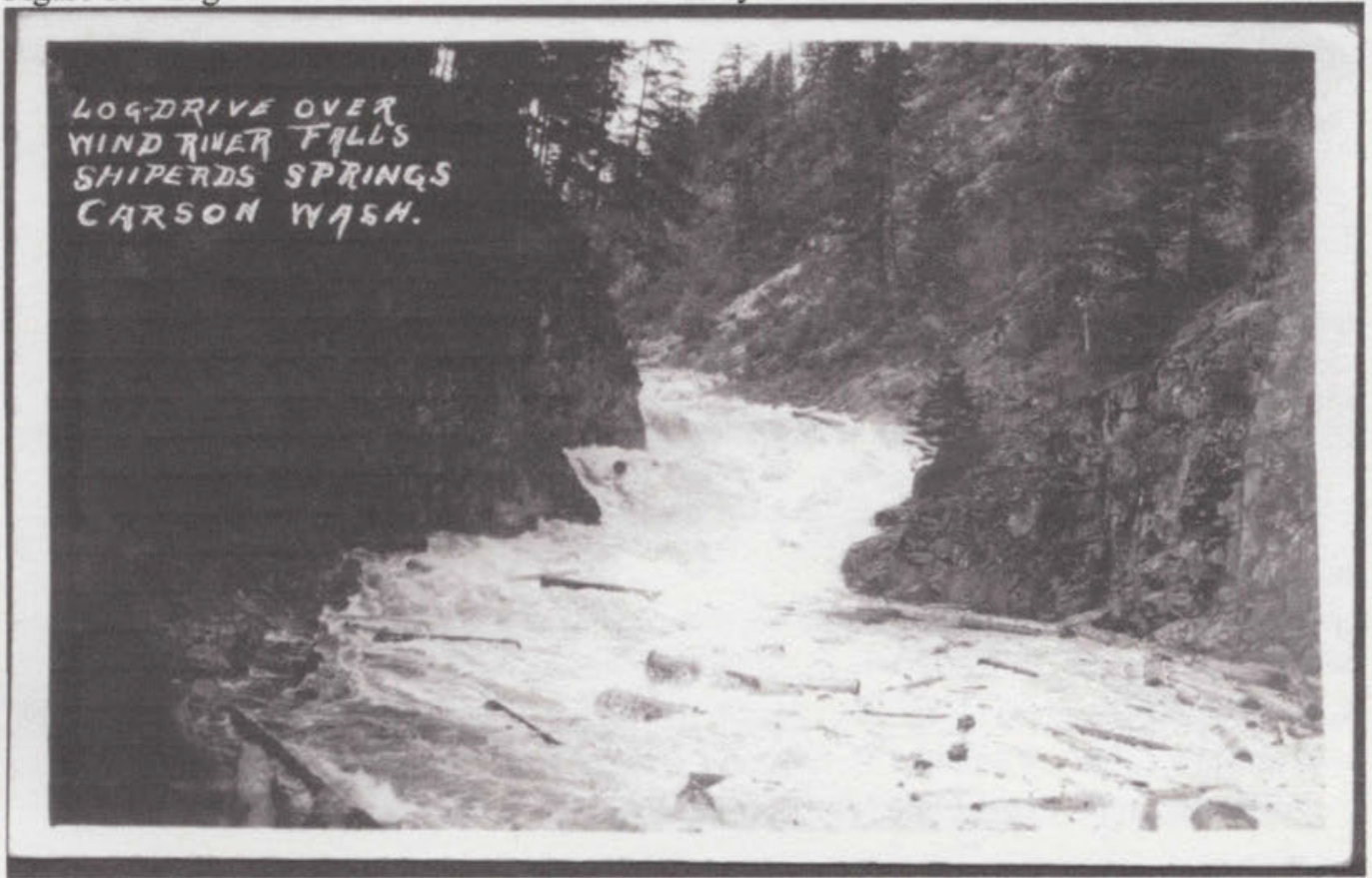

In 1902, the Wind River Lumber Company purchased Storey-Keeler Lumber Company and mill whose holdings included some of the best timber in the Upper Wind River Valley. The company continued appropriating private lands, which

\footnotetext{
${ }^{18}$ Phoebe Yeo interview, 10.

${ }^{19}$ Tolfree, "History of Wind River, Pt. I," 3-6; Auditor's files; Phoebe Yeo interview, 20.
} 
Storey-Keeler had begun along a two-mile corridor on both sides of the Wind River, beginning at the confluence of Trout Creek and extending northward to the confluence of Paradise Creek. By 1904, the Wind River Lumber Company owned the majority of privately owned land in the upper portion of the valley, working closely with the Skamania Boom Company, which had also quietly purchased lands, choosing them carefully at constrictions in the Wind River.

By 1906, the Wind River Lumber Company had established four logging camps along the Wind. The company located Camp Two south of Martha Creek, Camp Three on Trout Creek, and Camp Four adjacent to the Wind. Logging camps included cookhouses, bunkhouses, and in some cases became regular settlements. Camps were composed mainly of single men, but families often lived in them. Mrs. Lindsay cooked for a crew of men at Camp Three, and her daughter Phoebe later remembered a day when her mother, alone in the camp, saved the lives of men blasting rock from the Wind River:

Dad had a crew of men down in that confluence, blasting those rocks. Well, you couldn't hear that water roaring, because they were down there where the water was roaring. And they phoned to Camp Three and told Mama that the dam at Camp One had broken, and the water was coming. And those men were down there, and they would have been caught like rats. There wasn't a soul in there at the camp that Mama could send. So my mother took Irene and ran down there, because ... [Irene] was too little, she couldn't walk ...But she went down there and she got there in time to save those men's lives down in that hole. ${ }^{20}$

The sounds and smells of the forest and camp, the bellow of the water, the smell of dank moss, and the recollection of exploding dynamite, each contributed to the

\footnotetext{
${ }^{20}$ Pheobe Yeo interview, 6, 20.
} 
haptic sense so vividly recalled by Phoebe Yeo. Logging was hazardous work and living in the woods was sometimes treacherous. Falling trees killed men and boys, children drowned, fingers were chopped off, and roaring water threatened lives. But it provided a living, and by the beginning of the twentieth century as nearby communities struggled over who would control forest resources, work in the woods had become a staple of the Skamania County economy.

\section{A Most Efficient Organization}

During the reserve period, the Bureau of Forestry conducted scientific forest studies and expanded reserve boundaries. Thornton T. Munger, who later headed the Section of Silvics in Portland's district Forest Service office, pointed out that the genesis of scientific study and the policy and procedure that provided the "warp and woof" of the Forest Service began during these early days. Forestry studies included observations dealing with growth rates, light, moisture, and soil requirements, reproduction, behavior in pure stands, and competition. The Forestry Bureau also studied the effects of lumbering upon reproduction and market conditions for yellow pine and red fir in the Northwest. Silvicultural studies focused on fire prevention, protection, and insect infestation, and developed lasting scientific forest management practices for the future. These studies, in addition to local publicity and education about the reserves' purpose, ultimately led to support by those with the power to effect change. ${ }^{21}$

\footnotetext{
${ }^{21}$ Pinkett, Gifford Pinchot Forester, 89.
} 
At the American Forestry Congress in January 1905, the forest reserves gained support from the owners of resource-based companies. Various lumbering, mining, stock raising, and manufacturing interests, in conjunction with the Secretary of Agriculture, the head of the U.S. Geological Survey, the United States Reclamation Service, and the General Land Office sponsored the Congress. Others, including senators, congressmen, educators, and editors, attended. The significance of the meeting of leaders was twofold: it drove the transfer of reserve management to the Department of Agriculture, and as Pinchot claimed, it reflected a change in public opinion toward the reserves. While some western timber men agreed in theory that the federal forest reserves would conserve timber and protect watersheds, others believed administration for practical forestry would be "impractical and valueless." Those who recognized the value of Pinchot's forestry practices to the lumber industry, however, quickly shifted from opposition to emphatic support. The Weyerhauser Timber Company in Washington already had an agreement with the Bureau of Forestry for management of 1.3 million acres of the company's timber land. The Bureau provided technical manpower, while Weyerhauser paid for field assistance. In 1903, the company and the Bureau implemented a working plan to log old growth and provide for immediate reforestation. Frederick Weyerhauser attended the American Forestry Congress, where he summed up industry support: "Practical Forestry ought to be of more 
interest and importance to lumbermen than to any other class of men." Pinchot's tree farming would finally have a chance. ${ }^{22}$

What Pinchot had hoped for and worked toward from the day he had entered the Division of Forestry in 1897 had finally come true. The Forestry Congress recommended transferring the Interior's forest reserves to the Department of Agriculture. On February 1, 1905, the U.S. Forest Service under the Department of Agriculture was born. The American Forest Congress identified forest preservation as a national issue by gathering together various interests and creating the Forest Service. In addition, the congress recommended purchasing forest reservations in the East, repeal of the Timber and Stone Act, and amendment of the lieu-land law. ${ }^{23}$ Repeal of the Timber and Stone Act and the lieu-land law amendment would prevent homesteaders from settling a piece of timbered land, and logging it off rather than proving up, then exchanging it for a different piece of public land. Ironically, forest preservation and repeal of public land laws had more to do with gaining legal industry access to resources, the vigor of scientists, and preservation for use, than any aesthetic preservationist purpose, as the nascent forest policy and administration soon demonstrated.

The Transfer Act revolutionized reserve administration. It gave command of over sixty-three million acres of public forest to an agency that had not controlled "so much as a square foot of Government land," thrilling Pinchot. The

\footnotetext{
${ }^{22}$ Timberman, 7 October 1903, quoted in Steen, "Forestry," 111; Steen, "Forestry," 111-112; Frederick Weyerhausuer quoted in Pinchot, Breaking New Ground, 255; Pinchot, Breaking New Ground, 254-255; Robbins, American Forestry, 23.

${ }^{23}$ Pinkett, Gifford Pinchot, 57; Pinchot, Breaking New Ground, 256.
} 
newly created Forest Service could receive money from the sale of any products or the use of any land or resources of the reserves for five years from the Act's passage. This meant revenue from grazing and water-power, and would soon mean revenue from timber sales. Increased funding allowed increased manpower. The Division of Forestry had employed eleven people in 1898, but the new Forest Service employed 821 in 1905.

Gifford Pinchot went to work immediately, putting his long-formulated plans into place. He wrote a letter outlining the forests' administration, and Secretary of Agriculture James Wilson signed it. These instructions set the tone for forest administration. Reserves were "to be devoted to the most productive use for the permanent good of the whole people, and not for the temporary benefit of individuals or companies." Forest resources must be regulated to ensure permanence. Water, wood, and forage should be conserved for use by the homebuilder, and secondly for the benefit of other interests such as agriculture, mining, and livestock. Local issues would be decided on local consideration, and conflicting issues should always be decided from the standpoint of the "greatest good of the greatest number in the long run." On the coat tails of the transfer, the agricultural bill of March 3, 1905, gave Forest Service officers the right to make arrests and to assist in enforcing the laws of the states and territories. Under the same bill, the new agency received permission to export timber and other products. 
It also changed the bureau's name to U.S.D.A. Forest Service, indicating use rather than reservation of resources. ${ }^{24}$

Conservationist use-based policies went immediately into place with the birth of the Forest Service. The 1906 Yearbook of the Department of Agriculture defined the agency's duties:

The Forest Service has charge of the administration of the National forests, and conducts examinations on the public lands to determine the propriety of making changes in the boundaries of existing National forest and of withdrawing other areas suitable for new forests; gives practical assistance in the conservative handling of State and private forest lands; investigates methods of planting and kinds of trees for planting, and gives practical assistance to tree planters; studies commercially valuable trees to determine the best means of using and reproducing them; tests the strength and durability of construction of timbers, railroad ties, and poles, and determines the best methods of extending their life through preservative treatment; and studies forest fires, the effects of grazing on forest land, turpentine orcharding, and other forest problems. ${ }^{25}$

These organizational goals meant scientific experimentation, utility, and rationality above all, objectives that would ultimately change the physical and social landscape in different ways in different places. Through the next several years under Pinchot and Secretary Wilson, the new organization created a foundation for the future. Wilson, who had placed agricultural instruction on a scientific and practical basis, also began cooperative extension programs in agriculture, home economics, and forestry. The Forest Service also conducted turpentine and

\footnotetext{
${ }^{24}$ Pinchot, Breaking New Ground, 257, 258, 260; Steen, "Forestry," 113; Pinkett, Gifford Pinchot, 58-59, 113; Pinkett says there's no reason to doubt the validity of Pinchot's claim that he prepared the letter signed by Secretary Wilson since it espoused basic principles long advocated by Pinchot before 1905. Pinkett, Gifford Pinchot, 59, n.1.

${ }^{25}$ United States Department of Agriculture, Yearbook of the United States Department of Agriculture, 1906 (Washington, D.C.: G.P.O., 1907), 455.
} 
chemical wood treatment studies at its Forest Products Laboratory in Madison, Wisconsin. The laboratory focused especially on testing commercial products other than lumber, especially those related to building the nation's infrastructure; railroad ties, telephone and telegraph poles, cross arms, and fence posts. Tests of timber strength, new woods, product manufacturing from wood, and statistical study of the production and consumption of lumber quickly met the organization's scientific goals. $^{26}$

To maintain use, create revenue, and develop efficiency, the Forest Service allowed the sale of mature as well as dead timber. The job of forest rangers included preventing forest fires and perceived "waste" of overripe timber, and protecting young growth to insure reproduction. Local rangers and supervisors could make timber sales between twenty and one hundred dollars, but sales for more than one hundred dollars had to be advertised and approved by the Chief Forester, Gifford Pinchot. Forest officers issued permits to nearby residents for up to twenty dollars worth of timber yearly for use, without charge, no small benefit since this amount of timber might supply firewood, fencing, and mining but also cordwood for sale or enough wood to construct a home. Up to one hundred dollars annually of free timber went to schools and road districts, churches and cooperative organizations, all within the bounds of regulated cutting to insure a future timber crop. Within its second year, the size of the national forests increased from

\footnotetext{
${ }^{26} 1906$ Yearbook, 67-68; "Biographical Note, James Wilson," from E-Library, Iowa State University, http://www.lib.iastate.edu/arch/rgrp/9-1-11.html [accessed January 15, 2004].
} 
$85,693,422$ acres to $106,999,138$ acres, with a revenue of $\$ 767,219.96$ compared to just over $\$ 60,000.00$ the previous year. ${ }^{27}$

To manage use the new Forest Service gained increased authority, a revolutionary change. "Before the Forest Service came into our hands, all we could say to whoever controlled a forest, public or private, was 'Please," wrote Pinchot. By July 1, 1905 Forest Service officers received The Use Book, written by Pinchot, which laid out Forest Service policy in less than 100 pages of general information, directions, regulations and special instructions, ranging from issuing permits to writing letters. One of the most significant policy directives in The Use Book was solving local questions on local grounds, a policy the Forest Service often found difficult to uphold. ${ }^{28}$

Gifford Pinchot has been called the Father of the Forest Service, and for good reason. He not only implemented forestry practices, but he also implemented organizational principles that extended from coast to coast, many of which have lasted for nearly a century. Pinchot's contagious enthusiasm for forestry, organization, and conservation imbued the service, which became known as one of the most efficient agencies of its day. The rigid directives of the Washington D.C. Forest Service office reached far into the field through The Use Book; however, matters such as selling timber or buying fire-fighting tools had to be cleared through the Washington Office. In keeping with advice received from long time mentor Professor Dietrich Brandis, Pinchot successfully established an organization

\footnotetext{
${ }^{27}$ Pinkett, Gifford Pinchot, 59-60; Pinkett, Gifford Pinchot, 59.

${ }^{28}$ Pinchot, Breaking New Ground, 258, 267, 281-282.
} 
with "a healthy feeling of professional pride and confidence, and esprit de corps." This could only be achieved through professional training, "both practical and theoretical," in an agency governed by a "working plan," through free discussion between officers. To this end Pinchot decentralized Forest Service administration.

District decentralization began in 1905. Grenville Allen, a Yale educated engineer and first Forest Supervisor of the Mt. Rainier Forest Reserve appointed his brother, E. T. Allen as district inspector. Men who had worked under the GLO before 1905 staffed many of the supervisor and ranger posts, and some like Harold Langille moved into other positions. By 1908 , the decentralization policy created further district independence in the interest of solving local problems on local grounds. Reorganization in December 1908 divided the forests into six independent districts under charge of district foresters. "Each was to be a Washington in miniature," writes Lawrence Rakestraw, "with the Washington functional organization, and the district forester was given practically full authority to run his district." To increase efficiency, the Forest Service reorganized northwest forests into twenty-six smaller national forests. The southern portion of the Rainier National Forest in Skamania County was cut off and renamed Columbia National Forest with headquarters in Portland, Oregon. ${ }^{29}$

Herbert O. Stabler, a graduate of the Yale Forestry School established by Pinchot, became Forest Supervisor of the Columbia National Forest, remaining from November 1908 to 1913 . Stabler's earlier career included traveling

${ }^{29}$ Pinchot, Breaking New Ground, 107; Rakestraw, “A History,” 215, 224. 
throughout the West surveying forest reserve boundaries, and working with the Washington Office staff of the Forest Service under Gifford Pinchot. The new Forest Supervisor's office in the Beck Building, a modern edifice with large, airy offices, was one floor up from the regional National Forest Headquarters where E.T. Allen worked. There, George Cecil became Assistant District Forester, C.J. Buck, Chief of Operations, Fred Ames, Chief of Silviculture, and Howard O'Brien, Chief of Grazing.

Secretary Agnes Scannell, one of many women who worked in Forest Service administration during its early years, recalled the opportunity to head west. Scannell trained in the Washington D.C. office, and in 1907 she recalled receiving a call for volunteers to work in the newly-established district offices. The western volunteers would receive a salary increase of up to $\$ 900.00$, paid fare, "the opportunity to cross the continent," and they would bring the rational efficient goals of the Forest Service to specific locales. The young woman decided to try her luck in Portland where she began to learn about the northwest forests. Her duties included dictation which she soon welcomed, "for I learned so much about the trees of the "Northwest." She remembered that the men she worked with were "well-trained for the work to be done," as most came from the Biltmore or Yale Forest Schools established by Pinchot. Scannell recalled the early years of the Forest Service with a sincerity that reflected the feeling in the offices and in the field during the agency's early years: "We were all young! Almost everyone in the 
Forest Service was young! And everywhere there seemed to be that vigor, that onward-push, that dauntless spirit that goes with youth ..." she declared. ${ }^{30}$

Youth, energy and scientific vigor for conservation, study, and use of the national forests imbued the Beck Building, where the men and women who had worked closely with Pinchot implemented the Chief Forester's vision. Placing eastern-trained men like Stabler in supervisory positions established the practical forestry goals of the Forest Service. It also made it possible to implement the chief forester's vision even at far off outposts. But most compelling was Pinchot's charismatic ability to sway Forest Service workers to his way of thinking. As Agnes Scannell recalled:

In the year 1906, conservation was a new concept in American national life; few there were who really grasped the connotation of the word. It became a familiar, everyday word to me in the Forest Service. It was conservation which saved America from a threatened timber famine that was coming so swiftly, had it not been halted by Gifford Pinchot's vision and his concern for future generations.... Naturally, while working in such an atmosphere, one could not help placing a great value on trees. I began to think of them as something almost human, for after all, they are something alive, something growing, something reproducing, something serving men. ${ }^{31}$

Scannell's reference to trees as seemingly human beings draws out both a descriptive and emotive sense of events and their context. ${ }^{32}$ Trees would almost consciously serve mankind, and the newly-created Forest Service would insure their service by implementing its practical vision.

\footnotetext{
${ }^{30}$ Lawrence Rakestraw, ed, "Documents: Gifford Pinchot, Agnes V. Scannell, and the Early Years of the U.S. Forest Service," Oregon Historical Quarterly 92, 1 (Spring 1991), 63-64.

${ }^{31}$ Rakestraw, ed, "Agnes V. Scannell," 68-69.

${ }^{32}$ Entrikin, Betweenness of Place, 11.
} 
One of the most significant elements in imposing forestry values on the northwest was hiring local men for forestry work so that local problems would be solved on local grounds, directed by strict Forest Service policy. Rangers "were to be selected 'when practicable, from the states in which they are to be employed,"' for the ranger would deal with the everyday details of forest administration.

Figure 11: Elias J. Wigal. Wigal hired men to assist him in building this cabin at Hemlock Ranger Station. Bunker Hill at left. Photo courtesy Gifford Pinchot National Forest

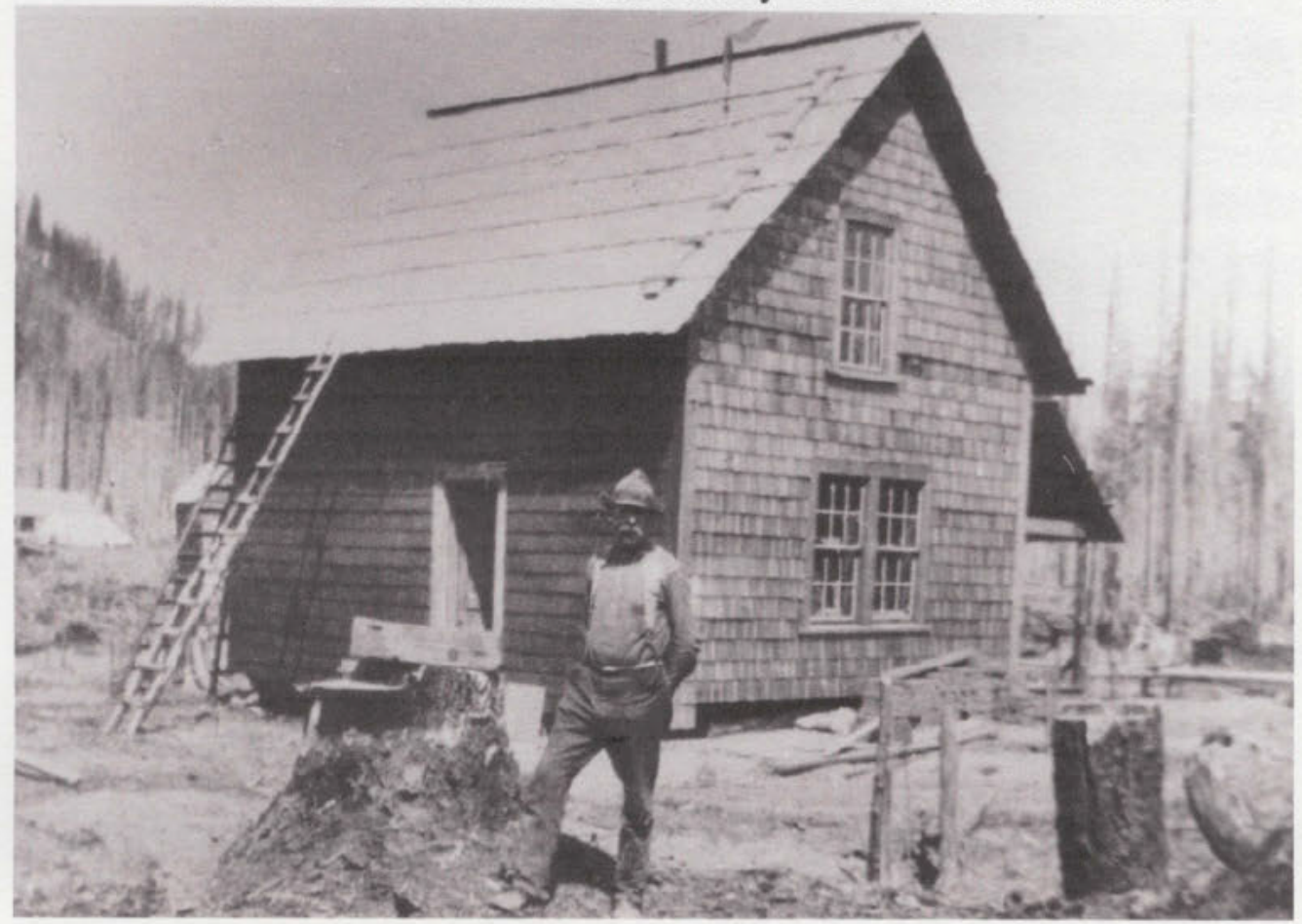

At the Hemlock Ranger Station, Wind River homesteader Elias J. Wigal became deputy forest ranger, and W.F. Jebe acted as scaler. Wigal had settled on unclaimed public land north of Carson in 1891, and had replaced the first ranger hired by the GLO, Horace Wetherell. Wigal served as a Forest Reserve ranger on the Mt. Rainier Reserve from 1904 to 1908, and administered the first timber sales 
on the forest. He also held at least two official positions with the Forest Service, Deputy Forest Ranger, and Assistant Forest Ranger. Wigal spent much of his time putting out small scale fires, making arrangements and scaling logs for timber sales, and maintaining efficient relations with the Portland office. Part of his duties included maintaining regular correspondence with Supervisor Stabler and regularly carrying the mail into town for transport. In turn, Stabler directed events on the forest by regular visits, and through daily correspondence. Wigal also spent much of his time maintaining the ranger station, issuing permits, and acting as firelookout. ${ }^{33}$

The Forest Service immediately worked toward a self-sustaining economic policy, and within two years began to pay for itself. Although grazing generated some revenue, timber provided the majority of the U.S.F.S. income. In 1906, Wigal administered the first federal large scale timber sale on the Columbia National Forest. At least two other timber sales occurred in 1906, but not as large as the Wind River Lumber Company sale. In keeping with recommendations by Secretary of Agriculture James Wilson, this was a three-year sale, and under new legislation the state would receive ten percent of the gross receipts from the sale, for the benefit of the county. Income from the reserves, Wilson determined in the 1906 Yearbook of Agriculture, "is as yet but a small fraction of what may be expected as they approach full utilization." By this time the Wind River Lumber company operated four logging camps in the forest and controlled nearly all of a

\footnotetext{
${ }^{33}$ Pinchot, Breaking New Ground, 280-181; Mack, Cheryl, ed., "Wigal Diaries," 1.
} 
two-mile corridor on the Upper Wind River. The complete sale yielded 14,626,520 board feet of timber for just under $\$ 13,000.00$. With access to federal forestlands and over 3,000 acres of private lands in the valley, the company became a major employer in the area and worked closely with the Forest Service during the three year sale. ${ }^{34}$

In 1907, the Wind River Lumber Company's Cascade Locks Mill burned and the company replaced it with an "up-to-date plant. . . in the face of the fact that they would practically have to depend upon National Forest timber for their supply." The new mill, dry-kiln, and other amenities at Cascade Locks represented a $\$ 250,000$ investment. Private timber, river improvements, camps, and machinery cost the company another $\$ 100-150,000.00$, giving it a large stake in the outcome of Wind River Valley struggles over resources. The company had the valley virtually "bottled-up," wrote Forest Supervisor Stabler. Any other interest would have to pay right of way to access the nearly 1.5 million board feet of timber standing in the Wind tributary valleys of Panther, Trapper, and Trout Creeks. By the end of the sale the company still owned 75 million board feet of standing timber, including a small portion on the White Salmon River. But the Forest Service controlled the remainder, and the new mill at Cascade Locks could cut 25

\footnotetext{
34 "Lost in Forest Fires," Pioneer, 6 November 1902; Rakestraw, "History," 152; McClure \& Mack, For the Greatest Good, 15, 22; Tolfree, "History of the Wind River, Pt. I," 6; Pinchot, Breaking New Ground, 293; 1906 Yearbook, 62, 63.
} 
million board feet of timber annually. To recover their investment, the Wind River Lumber Company kept on cutting. ${ }^{35}$

And to maintain credibility and appease local antagonism, Stabler worked to help the forest become self-supporting "and then some." To that end plans for another sale began immediately. The Forest Service opened some lands in sections fourteen and twenty-seven to settlement soon after the Wind River Lumber Company removed the timber in the 1906 sale, and the Forest Service recommended two small tracts in Section 26. Meanwhile, as the battle raged over agricultural lands, the Forest Service extended its control over the valley. ${ }^{36}$

\section{Homesteading in the Forest}

Agricultural lands within the forest reserves became available for settlement just as the Bureau of Forestry began selling timber from federal timberlands. Throughout the nation many of the forest reserves contained agricultural lands, mainly in river valleys "where the narrow and irregular tracts are good for grass or cultivation, usually irrigated, and yet not suitable to the growth of timber." These lands could be fenced and farmed under permit, but no more than forty acres could be occupied. A Public Lands Commission, investigating amendments to the land laws, especially those applying to timber, reiterated that “... the purpose of the

\footnotetext{
${ }^{35}$ H.O. Stabler to District Forester, 14 November 1910, Forest Service File 2400-10, Gifford Pinchot National Forest Headquarters, Vancouver, Washington, Wind River Lumber Company, 217-12, Columbia Sales, 3.

${ }^{36}$ Stabler to Forester, 14 November 1810 ; H.O. Stabler, "Homesteads in the Columbia National Forest Sold to the Wind River Lumber Company," 3 January 1913, Forest Service File 2400-10, Wind River Lumber Company, 3.
} 
forest reserves is for the benefit of the people." ${ }^{37}$ The Committee proposed a bill in

March 1904 recommending that forest reserve lands should be disposed of to "actual" settlers:

... with a view to permitting the occupation under the homestead law of such tracts as are chiefly available for agriculture and yet necessarily surrounded by the forest reserves. It is provided that such tracts may be ascertained and desribed by the Land Department and open to homestead entry only. The tracts not to exceed $11 / 2$ miles in length and not to exceed in area 160 acres. The bill provides that homesteads of this character shall not be commuted nor be subject to exchange under the lieu-land laws. It is thought that such homesteads should not be commuted because anyone who goes into a forest reserve to occupy a homestead should go in with the intention of remaining for at least... five years. ${ }^{38}$

Amendments by the Forestry Bureau prompted recasting the bill so that tracts could not exceed one mile in length. Passed on June 11, 1906, the legislation considered multiple forest issues, including: forest experiment stations; power plants; new reserves; game preserves; and restrictions on appropriation or destruction of American antiquities. In addition, legislation prohibited cutting, chipping, and boxing trees on public lands and forestlands opened to agricultural settlement. On June 11, 1906 the Agricultural Settlement Bill passed. Known as the Forest Homestead Act, or simply June $11^{\text {ths }}$, the bill made up to 160 acres available for settlement, subject to approval by the forest supervisor. Forest homesteads could not be commuted, meaning settlers had to actually live on the

\footnotetext{
${ }^{37}$ United States Congress, House, Committee on Public Lands, Entry of Agricultural Lands Within Forest Reserves, report submitted by Mr. Carter, 59th Congress, 1st sess., Report No. 3291, 2; Pinchot, Breaking New Ground, 268; United States Congress, House, Committee on the Public Lands, Entry of Agricultural Lands In Forest Reserves, report submitted by Mr. Lacey, 58th Congress., 2d sess., Report No 2078 (31 March 1904), 1.

${ }^{38}$ Lacey, Entry of Agricultural Lands, 1.
} 
land for five years. ${ }^{39}$ Gifford Pinchot laid out the terms for "valid" claims for bona fide settlers in The Use Book. Those holding legal title in forestlands:

....are free to occupy and enjoy their holdings, but must not interfere with the purposes for which the reserves are created, and must not cut timber or make use of forest-reserve land without a permit, except within the limits and for the actual development of their claims. Any other use will constitute trespass. ${ }^{40}$

Part of the job of a forest ranger became protecting valid claims, identifying illegal holdings, and examining lands deemed agricultural by potential settlers, a sometimes complex proposition. In the Cowlitz Valley, for example:

Some of the homesteads there had been made by local boys on timberlands. Their economy was a mixed one; they would clear a garden spot, split cedar shakes for sale, and work out part of the year. Such lands were not, within the meaning of the June 11 act, homestead lands, yet the occupants were engaged in genuine homestead activities. On the other hand, listing such lands as homestead lands would logically make all level timbered lands subject to alienation or settlement. ${ }^{41}$

Forest Homestead fraud took place often. Many classifications of fraudulent homesteaders existed, according to Alfred L. Thayer: "the person who deliberately sets about to defraud the government out of 160 acres of land, and the party who has been the victim of a professional locator, working in the interest of some large corporation." In "The Fraudulent Homesteader," Thayer described a forest homesteader who claimed land in the Cascade Mountains forty miles from his Everett, Washington, home. When Thayer explained that regulations required

\footnotetext{
${ }^{39} 1906$ Yearbook of Agriculture, 532; Carter, Entry of Agricultural Lands, 3.

${ }^{40}$ United States Department of Agriculture, Forest Service, Gifford Pinchot, Forester, The Use Book: Regulations And Instructions For The Use Of The National Forest Reserves (Washington, G.P.O., 1906), 20.

${ }^{41}$ Rakestraw, "History," 258-259.
} 
living on the claim, the man replied astonishedly, "Why, hundreds of people in this country have taken up claims back in these mountains, and have never been on the land." Refusing to relinquish his claim, the man explained:

My boss [a mill owner] sent me out with the company cruiser to see the land, go over it, stay out there for a couple of nights, and then the lawyer fixed up the papers and told me what to say when I went to the land office. I tell you right now, I ain't going to give it up, for the boss has been to big expense, and if I back down, he may fire me. ${ }^{42}$

The man finally relinquished his claim to the General Land Office, and Thayer went on to describe the fraudulent locator. The man he called Cascade Bill took advantage of hundreds of people, mainly hard-working immigrants seeking the American dream. Not only did he charge a $\$ 325.00$ locating fee for illicit claims, sometimes on his own land, but he also regularly swindled settlers out of money to repair a bridge that was not damaged. ${ }^{43}$

Due to potential land fraud, the difficulties in land classification, and forest boundary work, rangers rigorously examined claims in the following years. E.T. Allen restored some forestlands to entry in the Rainier Reserve, based on a letter from Pinchot's Associate Forester Overton Price, urging liberal interpretation of the agricultural law on the grounds of political expediency. Price later decided future doubt should be resolved on the side of the Forest Service. In a March, 1910 Supervisor's meeting at least one forester urged conservatism regarding forest homesteads. There was:

\footnotetext{
${ }^{42}$ Alfred L. Thayer, "The Fraudulent Homesteader," Conservation, 15, 11, (November 1908), 580.

${ }^{43}$ Thayer, "Fraudulent Homesteader," 579, 581-584.
} 
... ample underdeveloped farm land outside the forests. Of the total area of $15,713,280$ acres in Washington, 5,970,670 was not available for agricultural use, being in national forests, parks, or military reservations, or city and farm lots. Of the remaining $9,735,610$ acres, 415,600 was improved farm land; 267,360 prairie land; $2,168,040$ cut over land; and $5,549,410$ timbered land. Thus there was $9,320,000$ acres awaiting development outside the forest. ${ }^{44}$

The main considerations for determining agricultural lands should be whether the public needed the land for forest protection, whether the area was mineral land, if it was valuable for timber, and finally, whether the land was valuable for agriculture. $^{45}$

By 1911, confused administration, unclear guidelines, and mistaken listings prompted the Columbia National Forest's Acting District Forester C.J. Buck to determine specific objective criteria for land classifications. Only complete, detailed reports should be submitted to the Forester. They must include a table of forestry values, market worth for the particular tract of land, type maps, statements regarding the necessity or lack of necessity for public services such as highways or water power, the percentage of grazing lands, the need for irrigation, soil borings, and very careful timber estimates. Determinations should be made on the basis of the "chief value" of the land, whether for a reservoir, agriculture, or timber. Such statistics and public consideration meant little to those claiming lands along the Wind River. What really mattered to county boosters, despite the incipient timber culture, was the idea of building an agricultural empire on the Columbia's north shore. The conflict that would soon take place between community members and

\footnotetext{
${ }^{44}$ Rakestraw, "History," 260.

${ }^{45}$ Rakestraw, "History," 261.
} 
the Forest Service reflected a polarity between worldviews, as well as each party's attempts to serve its own self-interest. The Forest Service imposed an external objective vision on the landscape, a sort of uniformity based in specific scientific spatial realities. For community members, as Entrikin puts it, place was "a condition of human experience," an experience shaped as much by their behavior toward, and ideas about, place as the material environment. ${ }^{46}$

${ }^{46}$ McClure \& Mack, For the Greatest Good, 33; Ibid; C.J. Buck to Forest Supervisor, Columbia National Forest, 1 November 1911, "settlement," Gifford Pinchot National Forest Headquarters, Vancouver, Washington, File \#5027, Homestead Claims, Wind River; Entrikin, Betweenness of Place, 1 . 


\section{CHAPTER FIVE: PINCHOT'S MIDNIGHT OF INFAMY IN SKAMANIA COUNTY}

\section{Scientific Forestry and Community}

In 1900 , the census enumerated 1,688 people in Skamania County. Within a decade, the number climbed to 2,887, with 387 in the town of Stevenson. As the Spokane, Portland and Seattle Railway entered the Columbia Gorge in 1907, southern Skamania County prepared to boom. While the Forest Service took hold of the Reserve and the Wind River Lumber Company planned its profits, residents promoted the agricultural bounty of their county. As the apple orchards of Hood River, Oregon, prospered on the Columbia's south bank, community members on the north side of the river developed grandiose dreams of their own mighty apple growing region.

The first step was a county fair, held in October 1908, the first in Skamania. The Pioneer credited the "reliable mildness" of the climate with the success of displays of nuts, grasses, grains, vegetables, and fruits at the fair. It also brought out intertown rivalries when residents of other communities claimed only Stevenson would benefit from the county fair. The Pioneer editor responded to complaints, writing that "Stevenson is not a foreign city; it is the county seat," and boosters went hard to work to take Skamania apples to the Hood River Apple Show. Roswell Shelly and helpmate assisted in setting up the Skamania apple display and P.S.C. Wills, using conservationist rhetoric, "found them most agreeable and efficient workers for the great good to the greatest number. .." 
According to Wills, not only did the display receive second prize, but "All agreed that for color, rich smell, juicy crispness, flavor and melting deliciousness, our sorts now ripe were perfect in every way," with a future as promising as the world-wide reputation earned by Hood River. Despite demonstrations of the purported agricultural wonderland in the heart of the gorge, the elimination of agricultural lands from the forest remained controversial. Meanwhile, the Forest Service planned its next endeavor on the same lands desired by community members in the Columbia National Forest. ${ }^{1}$

The development of scientific forestry emphasized silviculture and studying forest conditions. In 1906, the Forest Service had six planting stations with an annual capacity of six million seedlings, and the Secretary of Agriculture decided nursery sites should be developed at every ranger station. ${ }^{2}$ By 1909 the Forest Service planned a nursery on the Columbia National Forest, with reforestation of areas affected by the Yacolt Burn of 1902 its primary purpose. In particular, the new nursery would supply seedlings to the city of Portland's 8,000-acre Bull Run watershed and other burned areas. Forest Supervisor Stabler decided that planting would be a good financial investment, and that the nursery should be located within the 160 acres withdrawn for Forest Service purposes comprising the Hemlock Ranger Station in the Wind River Valley. The nursery land stood in part of township 4, Range 7 E, bordering Trout Creek, and consisted of portions of the

\footnotetext{
${ }^{1}$ State of Washington, The Washington State 1999 Data Book (State of Washington: Office of Financial Management, 1999), 278, 280; “Zig Zag Zephyrs," Pioneer, 22 October 1908.
} 
former Wind River Lumber Company sale. It also comprised a portion of the land sought by Chenowith in the 1902 petition for the elimination of agricultural lands. Stabler chose this location, which sat on a broad flat about 50 feet above the level of Trout Creek at about 1,300 feet altitude, because it had "a first-class soil for nursery purposes." and numerous other desirable qualities:

The area is protected on the west and south by hills, but open toward the Wind River valley on the east and north. The climate is mild and adapted to raising general agricultural crops. The growing season is long, extending from the middle of April or May to well into September.... The nursery is very accessible both to labor and supply markets and to the various planting sites. Ash, Washington, the nearest station on the Spokane, Portland \& Seattle Ry. is 55 miles from Portland, and 14 miles by wagon road from the nursery. The town of Carson, $1 \frac{1}{2}$ miles from Ash on the road to the nursery, contains several general stores from which small supplies can be obtained....The Wind River Lumber Company, which operates its camps within a mile of the nursery site, is contemplating building a logging railroad up the valley from Ash. This will make the Station still more accessible. $^{3}$

Brush covered the ground near the Hemlock Ranger Station, with burned stands of denuded timber reaching to the sky. Within the next few years rangers established buildings, planted trees and orchards, and brought dozens of men and women to work at Hemlock during spring planting season.

During the winter of 1909, Assistant Ranger Wigal received a letter from Stabler authorizing him to hire a few men to start clearing ground for the nursery site. Wigal and the men blasted blackened tree stumps and by May 1910 began sowing. The first orchards were composed of unexpected varieties of trees for

21906 Yearbook of Agriculture, 67. 
experimental purposes. The ranger and his temporary assistants sowed hardwoods such as walnut and hickory, with Douglas fir and western white pine providing the majority. In addition, the Bureau of Planting sent fruit trees, and the nursery crew planted a grove of apple trees, a pear tree, a chestnut tree, and some cherry trees.

Similar trees went to other regional stations so the Bureau of Planting could assess the adaptability of varieties in a wide range of stations with similar climates. The dry season of 1909 and 1910 prevented much growth in the first batch of trees, but the Forest Service persisted. ${ }^{4}$

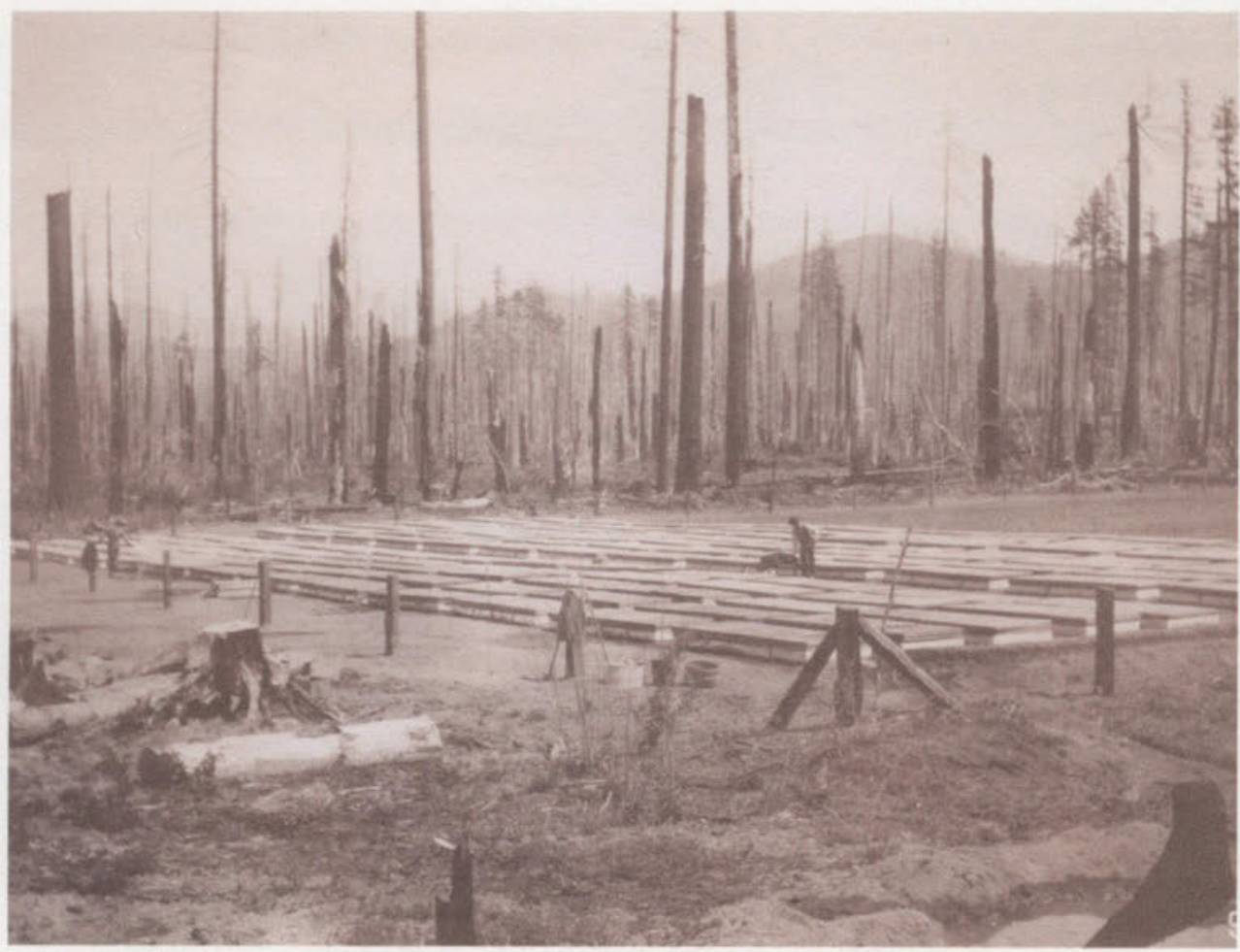

Figure 12: Wind River Nursery, ca. 1909-1911. Burned snags reveal the haptic sense that prevailed at the nursery during the early twentieth century. Photo courtesy Gifford Pinchot National Forest

${ }^{3}$ H.O. Stabler report on the Wind River Nursery, Gifford Pinchot National Forest, Wind River Training Center, Unnamed File, Early Forest Service Wind River Collection, 3, 4.

4 "Forest Ranger Fruit and Ornamental Gardens," Gifford Pinchot National Forest, Wind River Training Center, File 5038, Studies - Fruit Trees. 
Within the next few years the nursery expanded rapidly, providing seasonal work for locals and others around the region. Thirty-two year old Charles Miner came to head the nursery in 1910 . Two buildings stood on the grounds and the nurserymen and rangers boarded in the same house. Eilert Skaar, a seasoned, moustached Wind River homesteader and Spanish-American War veteran who smoked a Merschaum pipe, acted as district ranger and cook that year. Twenty-nine year-old Arthur Wilcox acted as Forest Assistant at the nursery, and two other men boarded with them - Harvey Lickel and Truman O. Kellog, both in their early twenties, acted as station guard and scaler. A second small building housed laborers, usually single men who found temporary employment with the Forest Service. In 1911, rangers and laborers cleared the remainder of the 10-acre site and installed a water system at Martha Creek. The same year the first large shipment of seedlings arrived, 99,000 fir trees, and nurserymen planted them at Warren's Gap, just north of present-day Stabler. Additional clearing took place that year and with the help of hired men staff added a warehouse and a combined residence and office building. They added four more varieties of apple trees in 1912, but none did well. The Warren's Gap trees also failed quickly. When examined, rangers found that less than half a dozen seedlings had survived. ${ }^{5}$

\footnotetext{
5 Lynn Andrews, “An Interview with Lynn Andrews," Interview by Rick McClure and Cheryl Mack, 17 June 1999, transcript, Heritage Program, Gifford Pinchot National Forest, Trout Lake, 5, 17; 1910 Census, "Columbia National Forest - Wind River Precinct" (April 19, 1910); Forest Assistant to District Forester Stabler, 28 August 1911, Gifford Pinchot National Forest, Wind River
} 
Despite the rough start, word about temporary work at the nursery got out fast. John Strong, temporarily employed on a steamer between Cascade Locks and The Dalles inquired about work at the nursery in February 1911, asking, "How soon are you going to start up the area in the spring let me no iff you want eney good men and How meny you will neade this year [sic]."

Assistant Forest Ranger Miner responded, telling Strong there would be work, but he could not guarantee when: "We expect to transplant about a million seedlings in the nursery and there are probably 35,000 hardwoods to set in the Forest. The size of the crews will depend somewhat on the arrangements to be made for board and accomodations..." A month later Miner told Strong he could not promise work for more than a few weeks and that Strong might be better off finding work elsewhere. Others inquired about work at the ranger station, and Miner hired some locals from nearby Home Valley to assist rangers in transplanting seedling beds in the fall. ${ }^{6}$

Ranger duties varied greatly at Hemlock. Sometimes the men assisted other districts around the forest. During the 1911 fire season, Ranger Fritz Sethe took a trip to Vancouver to join Forest Guard Freudenburg to act as fire look-out on the

Training Center, File - Columbia-Planting, Warrens Gap; "Wind River Nursery timeline, 1933," Gifford Pinchot National Forest, Wind River Training Center, File 5016; "Fruit Trees," Gifford Pinchot National Forest, Wind River Training Center,File 5038. The trees were not received in good condition. They had "very short, poor roots on them. Wrapped in oiled paper and were in very good condition," when sent, that is. (Note at bottom of Memorandum for Forest Rangers from Bureau of Plant Industry, April 18, 1912).

6 John Strong to Charles Miner, 15 February 1911, Charles Miner to John Strong, 23 February 1911, Charles Miner to John Strong 12 March 1911, Charles Miner to Andrew Frost of Home 
Gumboot-Copper City Trail, near the East Fork of the Lewis River. Sethe traveled on horseback to Cougar, Washington to locate a trail, then back to Hemlock by way of Woodland. Meanwhile, Miner assisted Forest Supervisor Stabler in preparing the annual planting report from Portland. By 1911, the Forest Service had built thirty-nine miles of wagon roads and 329 miles of trail systems, and private and Forest Service telephone lines covered thirty-five miles within the forest. Eight rangers cabins were in use along with pastures and fencing at Hemlock. The Forest Service had determined that the land at Hemlock was ideal for many uses, including a nursery and experiment station. As the Forest Service became more firmly established in the Wind River Valley, the battle between the federal government and the Skamania County Board, now known as the Board of Trade, heated up. ${ }^{7}$

Valley, 7 September 1910, Gifford Pinchot National Forest, Wind River Training Center, File SPZ, Columbia-Nurseries, Wind River. 


\section{The Battle Thickens}

In 1911 Portland businessman Loren Grinstead wrote a letter to former senator and Chairman of the Committee on Agriculture, Charles Scott. Grinstead described a visit by Governor Hay of Washington to the town of Stevenson in southern Skamania County:

we showed him about one hundred thousand acres of meadow and brush land which is chiefly valuable for agriculture and has no commercial timber to speak of. This was included in the blanket proclamation as a part of that midnight of infamy when Pinchot and Roosevelt conspired to defeat a law of Congress by railroading a lot of farming land into forest reserves 'to be eliminated later,' if found valuable for agricultural purposes.

Skamania County was under attack, Grinstead claimed, the government supporting timber monopolies rather than enterprising farmers:

for miles and miles of cut over land there is not a tree big or little left standing. They get dead timber for half price and it is a strange coincidence that about the time one dead tract is denuded, the fires 'break out' and destroy about as much as can be cut during the next year. It is the rottenest deal ever perpetrated on any people. No wonder all the big lumber concerns are all for 'conservation' as she is understood by Pinchot, Weyerhauser, Walker, Tom Shevlin, Smith, et al. ${ }^{8}$

Grinstead's letter, exemplifying the antagonism felt by many county residents

toward the government, was part of the ongoing argument over the Wind River Valley. Differences between an internal view of the Wind River Valley as a

${ }^{7}$ H.O. Stabler to Fritz Sethe, 2 September 1911, 27 May 1911, H.O. Stabler to Charles Miner, 6 February 1911, Gifford Pinchot National Forest, Wind River Training Center, Disbursements file; P.S.C. Wills, "Zig-Zag Zephyrs," Pioneer, 22 October 1908; Pioneer, 9 February 1911.

${ }^{8}$ H.O. Stabler and W.G. Hastings, "Report on Agricultural Development and Possibilities, Alienations and Timber Sales Within the Wind River Valley of the Columbia National Forest," 20 October 1911, Gifford Pinchot National Forest Headquarters, Vancouver, Washington, File 2700-1, LB Boundaries, Stevenson Memorial Data. 
community resource and an external perception by those who laid claim "for the greatest good," resulted in a long term struggle between the Forest Service and county residents.

As the Forest Service expanded its operations, the Board of Trade focused on promoting north shore gorge communities. The contest for lands in southern Skamania County heated up. ${ }^{9}$ William P. Christensen, a former state senator and land office registrar in Minnesota moved to Stevenson in 1908 and formed the Bank of Stevenson, serving as its cashier. In 1911, as Chairman of the Board of Trade and a state legislator, Christensen pushed House Joint Memorial 4 through the Washington State Legislature. The Memorial, calling for the elimination of over 100,000 acres of land, nearly the southern half of the Columbia National Forest, passed the State Legislature in February 1911. By the end of the year, the memorial went to the Secretary of Agriculture, the President of the United States, and Congressional members. ${ }^{10}$

As the contest for lands in southern Skamania County heightened, the hopes of Stevenson businessmen soared and news editorials became increasingly sharp. When acting Secretary of Agriculture Willis L. Moore declared the desired Wind River Valley tracts "practically worthless for agricultural purposes," the Pioneer retorted:

\footnotetext{
9 P.S.C. Wills, “Zig-Zag Zephyrs,” 22 October 1908; Pioneer, 9 February 1911.

10 "Death of William P. Christensen," Pioneer, 14 May 1914; Memorial of the Legislature of the State of Washington and Petition of Skamania County for Elimination of Lands from Columbia
} 
We should like to know how a man sitting in a armchair in Washington, who has never been within 3,000 miles of that land can know whether or not it is worthless for agricultural purposes... How do they expect the people of Skamania county to be good loyal citizens and have a deep veneration for their country and its institutions and give the administration their patriotic support when they wring in their same old lie on us every time we try to do something for ourselves? 11

The county fathers viewed self-promotion as the key to success. Carson, located twelve miles north of the Columbia River at the south end of the Wind River Valley on the North Bank Railroad, was hailed by the Carson Journal as the "coming metropolis of Skamania County." Local promoters tried to evoke an open attractive sense of place to draw newcomers to the town. The Carson Valley would provide an "Ideal Home and Prosperity" for those willing to settle in this "... beautiful valley embosomed among the protecting ridges of the Cascades. The soil and climate," declared an ad for homesteaders:

are unexcelled for the production of the extra choice grades of fruits produced in the Columbia Valley. Carson Valley is located fifteen miles west of Hood River Valley and forty miles east of Portland, and extends north from the Columbia for a distance of thirty miles on a water grade. 20,000 acres choice land now available.An irrigation ditch is now under construction which will furnish 4,000 acres which can be extended as needs require."12

Again, community promoters used agricultural rhetoric to expound the virtues of the good life in Carson, and to shape their own identity. County boosters and real estate developers boasted the region held more opportunity than anywhere

Forest Reserve, December 30, 1911, Gifford Pinchot National Forest Headquarters, Vancouver, Washington.

11 Pioneer, 19 June 1911. 
else in the Northwest. Put initiative and hustle to work and a man could launch new enterprises in this town of electric lights, and sparkling piped spring water. Community services included a church and "graded" school, two barber shops, and a newspaper. Retail and business services included a steam laundry, two general stores, a drug store, a hardware and furniture store, cigar factory, shoe and harness shop, and a confectionery. For recreation, the town touted two mineral hot springs health resorts. The natural landscape of the St. Martins Hot Springs and the Mineral Springs Hotel Co. drew tourists to the area and Government Mineral Springs, ${ }^{13}$ under development in the National Forest, was "one of the best mineral springs on the continent," claimed the Carson Valley Development Company. ${ }^{14}$

12 Carson Journal, 20 January 1911.

13 Interestingly, Government Mineral Springs was not among the many mineral springs identified by Plummer in the 1900 forest survey. The resort that was built at Government Mineral Springs attained a regional reputation as a sophisticated city getaway, replete with dinners, dancing and much revelrie. The hotel burned down in 1936.

14 Carson Journal, 20 January 1911. 


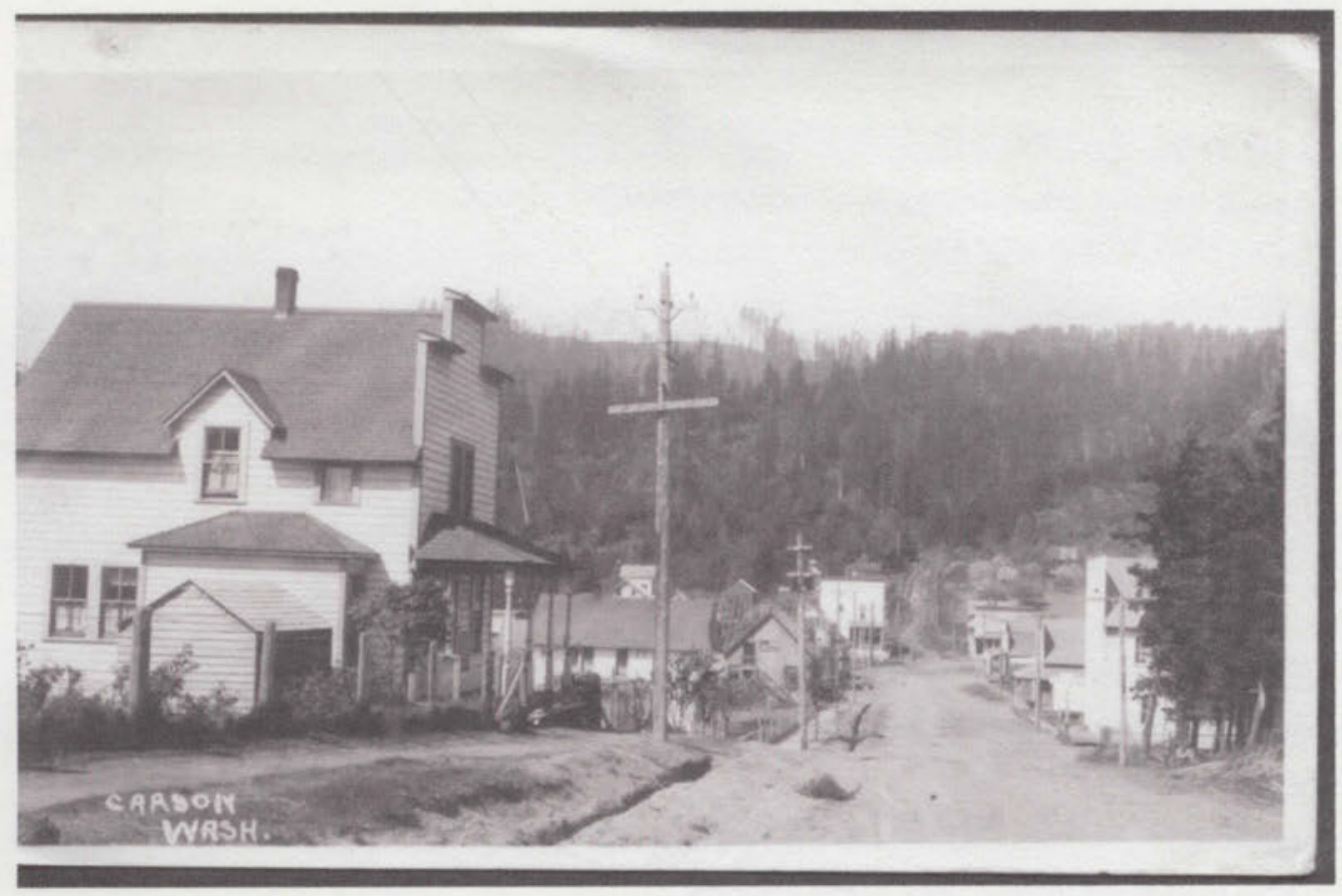

Figure 13: Carson, Washington, ca. 1915. Photo courtesy Gifford Pinchot National Forest

In April 1911, the Board of Trade printed one thousand copies of a promotional article touting apple lands, cherry lands, truck farming lands, pear lands, berry lands, and poultry ranches. The newly formed Northwest Development League, a regional organization created to promote the northwestern "Zone of Plenty," applauded the Board's efforts. The promotions were not completely invalid. That year, the Skamania County Board of Trade, with its new leader, took second place at the Spokane Apple Show. Promoting the climate, soil, and location, the Board of Trade declared that "From now on Skamania county is going to grow ... Land is selling here from $\$ 100$ an acre down as low as $\$ 25$ per acre and there is no land in Oregon or Washington superior to it for fruits and vegetables." 
The Board of Trade also took an active role in community development. In 1910 women became enfranchised in Washington State and the following year the Board decided to either form a ladies auxiliary or take women into full membership. They chose the former, and women from the auxiliary went to monthly meetings and provided food baskets for fundraisers. The Board held social meetings and with the ladies' assistance held a Spring Ball. The Stenon Orchestra played "excellent" music, and card games, singing, recitations and speeches accompanied a banquet. "Food [was served] that had been prepared by the Ladies Auxiliary and was fit for the gods," declared the Pioneer, "....and everybody enjoyed themselves and inquired when the next social meeting would be held" In June, the Board of Trade held "an entertainment" at the Stevenson Opera House. The newspaper declared the card party, recitations, singing, dancing, strawberry supper and skit titled "Dodging for a Wife. . just a little too delicious for anything."15

As the Board of Trade forged community bonds, it continued to promote the region's agricultural potential. Professor H.W. Sparks of the Washington State Agricultural College set up a demonstration station a mile west of Stevenson, and local settlers learned about removing stumps by the char pitting method. That the method was so successful, according to a local rancher, was just more evidence of

15 Pioneer, 13 April 1911; Douglas Edwards, "Advertising the 'Zone of Plenty': The Northwest Development League and the Incorporation of Regional Identity," Unpublished paper presented at the 39th Annual Conference of the Western History Association (Portland, Oregon, October 6-9, 
the region's agricultural vitality. Settlers cleared more land that year than any other year in the county's history. During the summer, the Board set up an agricultural exhibit near the train depot, sporting a limb of seedling cherry "so loaded that nothing could be seen but the fruit." A branch from a cherry tree donated to the Pioneer the week before caused the paper to declare: "the wonder is that one small branch can give nourishment to so many cherries and how it can sustain such a load. . . This is surely the gratest place in the world for cherries"16

Promotional agricultural efforts soon connected to creating a transportation infrastructure to access forest resources. William L. Richmond of the Board of Trade called for a good road north of Stevenson and into the National Forest in 1911, when John Sweeney discovered ore - copper, gold, and silver, just east of the city of Stevenson. Joe Douthitt ${ }^{17}$ and Neil Williamson unearthed the same vein sixteen miles northwest, and Richmond claimed that the discovery was yet another opportunity for the county seat to become "the greatest and best town on the Columbia River." A road entering the national forest would bring "thousands of people" to Skamania County, and Richmond declared that the government would soon be compelled to throw open the reserve and remove the over mature timber. That would leave the soil exposed, "the true wealth. . . soil that cannot be surpassed by anything in the northwest." In addition, a road to the $\$ 50,000$ hotel under

1999), 1; "Board of Trade Meeting," Pioneer, 12 January 1911; Pioneer, 6 April, 18 May, 22 June 1911.

16 Pioneer, 6 April, 22 June, 13 July 1911; “A Demonstration Station,” Pioneer, 28 February 1911. 
construction at Government Soda Springs would bring tourists and their money to the forest. The Board held a meeting to discuss the road and Richmond admonished "everybody" to come out for this matter of "vital importance." However, few attended due to preparations for the upcoming Fourth of July holiday.

Even without full community participation, the Board viewed agricultural success in Skamania County as just a stone's throw away in the national forest. Seeking to fulfill its mission, on July 12, 1911, the Board held a special meeting and made arrangements to photograph desired areas of the reserve and to collect grasses and soils to augment their argument. The Board chose thirty-year resident C.J. Moore to spend the next several weeks surveying the forest. Moore examined the valleys of Wind River, and Trapper, Trout, and Dry creeks, collecting evidence that "many thousands acres of superior agricultural land have been wrongfully included in the Columbia forest reserve and should at once be eliminated therefrom." 18

17 The spelling for Joe Douthitt's name varies in the historical record from Douthitt to Douthert to Doumitt.

18 Pioneer, 6 April, 13 July 1911; Memorial and Petition, 4. 


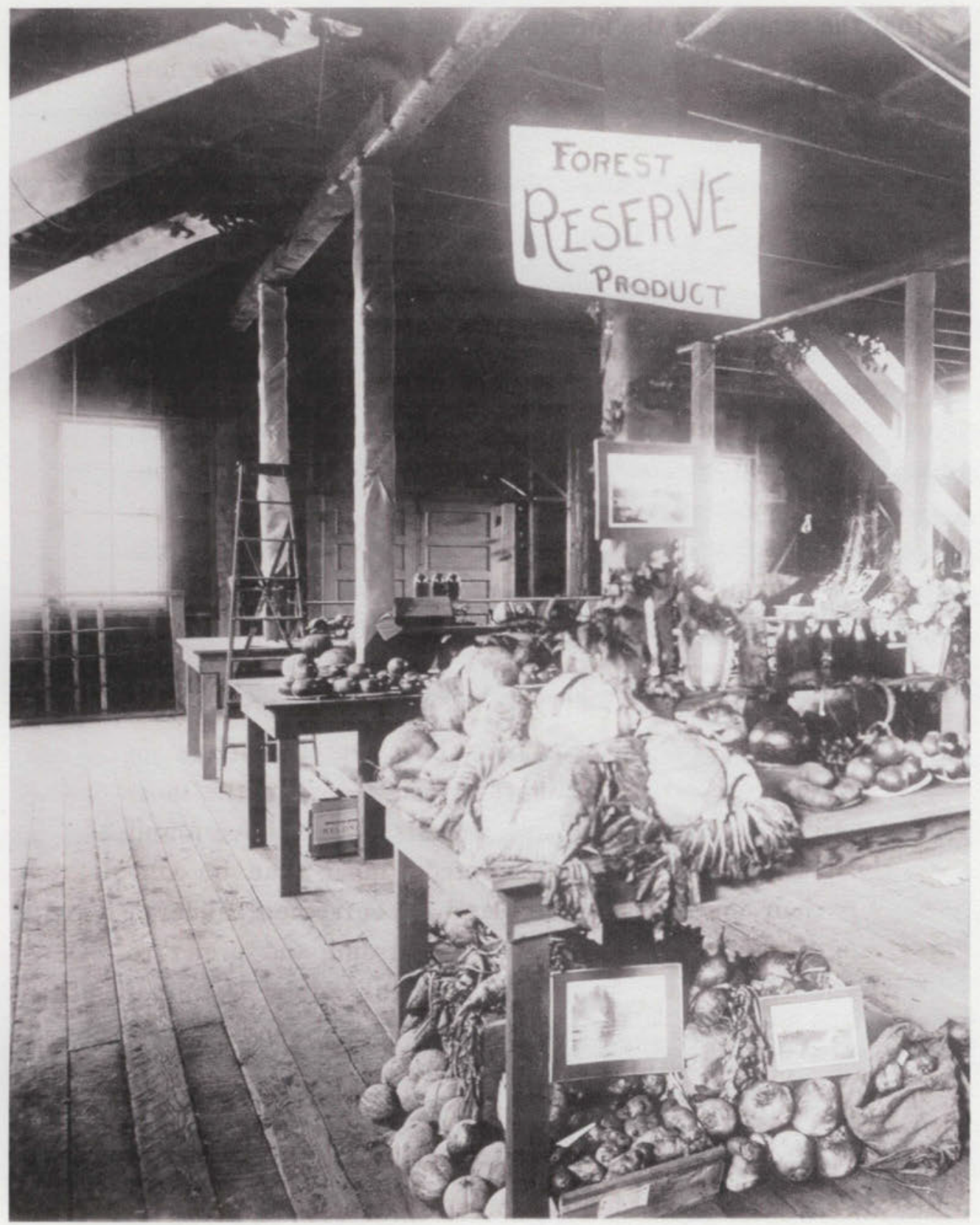

Figure 14: Forest Reserve Products, 1911 photo from Memorial \& Petition for elimination of lands from the Columbia National Forest. Photo courtesy Gifford Pinchot National Forest. 
The 1911 county fair included a special forest products exhibit with prizewinning specimens produced in the Columbia National Forest. In October 1911, the Board of Trade claimed the forest products exhibit probably the most attractive feature of the fair:

It was certainly a stunner - taking into consideration the official statement of the Forestry Department that this great empire Skamania county is 'absolutely worthless.' It was a remarkable demonstration of the great fertility of the soil and unlimited variety of products that can be grown to perfection in the beautiful and fertile valleys of the reserve in this county. ${ }^{19}$

P.S.C. Wills also proclaimed the exhibit's success. He pointed out to readers that while apples and pears were from some of the older homesteads, many of the grains, clover and vegetables came from newly sowed stumplands, just one more reminder that the reserves should be opened. The Board of Trade noted that exhibit products all came from elevations between 300 to 1,600 feel above sea level, all produced in the Columbia National Forest. ${ }^{20}$ The Board proclaimed:

The righteousness of our position is seen when it is understood that what is here shown as the product of a few bits of cultivated land in the reserve are but samples of what can be produced on one hundred thousand acres of similar land now locked up and forbidden to the people. ${ }^{21}$

The stakes for the Wind river lands rose as politically savvy members of the Board of Trade made a public attempt to gain access to the forest. William P. Christensen invited Governor Marion Hay of Washington to Stevenson. The governor accepted, and with the state highway commissioner and John E. Chappell,

19 "Letter from the Board," Pioneer, 26 October 1911.

20 "Zig-Zag Zephyrs," Pioneer, 18 September 1911. 
state senator for the district, the governor accompanied members of the Board of Trade in a survey of the roads and forests of the southern portion of the Columbia National Forest. Christensen, Colonel A.R. Greene, businessman E.P. Ash, Sam Sampson, and John Grinder, editor of the Skamania County Pioneer, took the governor to Soda Springs, approximately eighteen miles north of Carson and twelve miles inside the reserve, where a large hotel and health resort were under construction by lease from the Forest Service. Next they visited the Hemlock Ranger Station where rangers were hard at work growing young firs to replant burned over areas. There, claimed the author of an August 31, 1911 editorial, “... the level land stretches for miles on both sides of the road, covered with stumps and snags and grubs, awaiting only the removal of these when it would be rich agricultural land and besides the entire valley could be irrigated." As the party headed back to Stevenson for an evening banquet, songs and accolades, editor Grinder quoted the governor having viewed the land in the reserve as "An empire lying dormant and inhabited only by the wild beasts and birds and a few loggers and forest rangers." 22

Within a month the proverbial logs hit the river. Chairman of the Agricultural Committee, Charles Scott, received the letter claiming inequity, fraud, and a "midnight of infamy" from Portland businessman Loren Grinstead who sided with the Board of Trade. Scott immediately sent the letter to Henry S. Graves who

21 Memorial and Petition, 11. 
had become Chief Forester the previous year when President Taft fired Pinchot because of his squabble with Secretary of Interior Richard Ballinger over leasing coal mines in Alaska. Scott vouched for Grinstead's integrity and suggested looking into at least one allegation, "That the reduced price at which burned over timber is sold may have something to do with the number of fires in the forest." Associate Forester A.F. Potter sent Grinstead's letter on to the Portland District Forester, calling for "a very strong reply."23

Forest Supervisor Herbert O. Stabler was just the man to do the job. Although Stabler had come from the East and worked in the fancy Beck Building, he could ride with the best of the Service's rough and ready rangers. The Pinchot acolyte spent time in the forest as well as the city, and had fought fires, and built trails like the rest. He worked on the ground with Wigal, and knew the southern portion of the forest well; and he was smart. Within two weeks he refuted all assertions of Forest Service misconduct, declaring it impossible to see 100,000 acres of land of any description on the ride from Stevenson to Soda Springs. The lands were not agricultural "in the most liberal and inclusive sense of the word," and most of the "miles and miles of cut over land" were already owned by the Wind River Lumber Company. The most insidious accusation of all, that "feasting and

22 H.O. Stabler and W.G. Hastings, "Report on Agricultural Development and Possibilities," Pioneer, 31 August, 14 September 1911.

23 H.O. Stabler, "Report on Agricultural Development and Possibilities,"; Charles. F. Scott to H.S. Graves, 1 October 1911, A.F. Potter to District Forester, Portland, October 6, 1911, Gifford Pinchot National Forest Headquarters, Vancouver, Washington, Forest Service File 2700-1, LB Boundaries. 
cajoling" scalers led to low priced stumpage was irrefutably denied through the records of the Wind River Lumber Company sale of $1906 .{ }^{24}$

In March, Stabler traveled to Washington D.C., where he composed a revealing handwritten note outlining the report he would submit to Congress. Stabler summarized the method he would use - a description of topographic, soil, and climatic forest conditions, a short history of agricultural development and what had become of the lands, and then he concluded: "After showing the land useless for any other purpose. if that should be the conclusion. show forest value, and demonstrate that it can be economically used only for the practice of forestry." Stabler conducted an intense, rapid, and thorough investigation. He felt that he knew best regarding the community, the forest, and the Forest Service, which convinced him not to open lands to agriculture. He furiously documented past abuses of homestead claims in the Wind River Valley, and set out to refute, acre by acre, the images and assertions contained in the Petition to Congress. ${ }^{25}$

Stabler's landscape assessment differed significantly from that of the Board of Trade. He authoritatively and scientifically discounted the petition's assessment of elevations, soils, and vegetation found in the southern half of the forest. If the locations given in the Memorial were correct, then Forest Service maps and timber cruises proved they were wrong about the land's value. He determined that

\footnotetext{
24 Stabler \& Hastings, Report on Agricultural Development and Possibilities, 2-6.

25 F.W. Reed, Acting Assistant Forester to District Forester, Portland, Oregon, March 2, 1911, "handwritten memo signed H.S.,"Gifford Pinchot National Forest Headquarters, Vancouver, Washington, Forest Service File 2700-1.
} 
approximately eighty-nine percent of the requested elimination was above 2,000 feet, with ninety-five percent above 1,500 feet. Lands at lower elevations were enclosed in narrow, v-shaped valleys making cultivation impossible. Although grasses, grains, and vegetables could grow, they often didn't mature. Where the petitioners photographed brushlands and open fields, Stabler showed "distant views," giving what he said was "a far clearer representation of the country as it actually exists than the photographs contained in the Memorial." The most significant element, Stabler pointed out in agricultural lingo, was the value of the land for "growing timber." The Wind River Valley held approximately one billion two hundred thousand board feet of timber. According to the scientifically trained forest supervisor, it would be possible to attain an annual cut between twelve and fifteen million board feet "for all time to come" through timber conservation. And that, Stabler wrote, was "in accord with the best interests of the people of Skamania County..."26

Stabler synthesized his conclusions in a Congressional report in May. He refuted the memorialists' claim based on his assessment of climate, topography, past land fraud abuses, and the inability of those who had claimed alienated land to make a living. Although sixteen applicants filed for lands under the Forest Homestead Act, only four patented the lands. Two of the four later relinquished the land for lack of school or church services, or because "the soil was a thin, rock

26 Memorial and Petition, 3; Stabler \& Hastings, "Report on Agricultural Development and Possibilities," 3-4, 12-13, 16, 19. 
strewn, volcanic ash, unfertile and nonproductive, located in a narrow, shut-in valley, the elevation of which was from 1500 to 2000 feet..." Although grazing was possible in some areas, the land was already at full capacity, with tree seedlings restocking burned over areas. Rather than agriculture or stock rearing on the high altitude burned lands, wrote the Forest Supervisor, "every means possible should be taken to foster the growth of a second crop of timber."27

As for past and future income to Skamania County, the forest reserve did comprise four-fifths of the county, resulting in minimal tax revenues. Only two timber sales of any value had yet been made on the Columbia Forest, both in the Wind River Valley and both to the Wind River Lumber Company. ${ }^{28}$ The company had been logging its own lands for a number of years, but would soon have the capacity to remove ripe timber from the lands proposed for elimination. The Agricultural Appropriation Act of 1909 allotted twenty-five cents of every dollar from forest revenues to the counties, and, proposed Stabler, "in comparatively few years, because the life of a county or state is by no means comparable to the average human life, the income from the natural resources included within the Columbia Forest will be far greater than the residents of Skamania County can now

27 H.O. Stabler, "Report on Elimination From the Columbia National Forest" Requested by House Joint Memorial No. 4 of the Washington State Legislature (15 May 1911), 6, 10-13.

28 The Wigal diaries indicate that there were two earlier timber sales, probably around 1904 during the Department of Interior, G.F. Allen administration. The sales were relatively large, covering several sections, at least one of which was adjacent to what would become the first Wind River Lumber Company sale in 1906. Wigal refers to them as the Douthitt and Gropper Timber Sale and the Reynolds Timber Sale. 
appreciate." Besides, once logged, lands appropriate for agriculture would be opened for settlement. Stabler concluded:

The request made in Joint Memorial No. 4 of the Washington State Legislature, to the effect that practically the southern half of the Columbia Forest Reserve be eliminated, should not be granted because the needs of the County of Skamania, the State of Washington, and the country at large will be better served by the administration of the land under the National Forest policy. 29

Stabler's report caused a stir, with Skamania petitioners next calling upon Senator Wesley Jones.

Washington citizens viewed Jones, a self-declared errand boy of the people and "conservatively progressive" Republican Senator from Washington, as a staunch supporter of settlers. Jones, who had grown up on an Illinois farm had begun his legislative career in Washington's House of Representatives, worked on public land and farmers' issues throughout World War I. Jones introduced legislation to extend homestead laws to soldiers of the Spanish-American War and Philippine Insurrection, prohibit the establishment or extension of forest reserves except by Act of Congress, provide relief for settlers on public lands, and proposed giving settlers free land on the Colville Indian Reservation. ${ }^{30}$ Although none of his early bills passed, agricultural hopefuls identified Jones as an ally. At the same time, writes Jones' biographer, Washington viewed itself as the "heir presumptive... to the fabled riches of the Orient, [and] he could be expected to

29 Stabler, "Report on Eliminaton," 16-19, 21. 
promote the fullest utilization of land and forest resources, [and] the development of commerce and shipping. In Jones' public land reports, written to accompany bills to limit the control of federal government over creation and expansion of forest reserves, he points out the "arbitrary" nature of reserve inception and the lack of consulation of local settlers when reserves were created. ${ }^{31}$

Jones seemed a good choice to assist the Skamania Board of Trade since he had supported citizens in Jefferson and Clallam counties, and in the Methow, Cowlitz, and Skykomish valleys with agricultural land eliminations. ${ }^{32}$ Within weeks of the request by the Board of Trade, Jones wrote to Secretary of Agriculture James Wilson enclosing a letter from William P. Christensen. Christensen claimed Stabler's assertion that only five percent of the lands were agricultural was untrue, that he had measured elevations without going into the valley. Jones told Wilson he would like to visit the lands and asked that final action be withheld until winter. "Personally," wrote Jones:

I believe that every acre of land that is suitable for a home or for agricultural purposes should be made available for those purposes and, while I am in favor of the conservation of our forests, I do not believe that no hundred and sixty acres of timber land that can be made suitable for agricultural purposes can be of the same value for timber in the aggregate... 33

30 In 1903 Jones was able to get this bill passed and free homesteads were provided to bona fide settlers on the Colville Reservation in 1903. William Stuart Forth, "Wesley L. Jones: A Political Biography" (Ph.D. diss., University of Washington 1962), 79.

31 Forth, "Wesley Jones," 56, 59-60, 66-67.

32 Forth, "Wesley Jones," iv, 56, 57, 59-60, 66-67; Rakestraw, "History," 261, 267.

33 Wesley L. Jones to James Wilson, May 25, 1912, File 2700-1, LB Boundaries. 
The Senator, described by Lawrence Rakestraw as "a man with a quick ear to the complaints of constituents against the Forest Service," 34 visited Stevenson in October, but the Board, having anticipated a chance to make their case, remained disappointed. Jones toured the forest with Forest Supervisor Stabler as guide. When the senator did not appear at a reception hosted by the Board of Trade, the community protested and the Pioneer declared:

He had been hobnobbing with the forest rangers out in the reserve for a couple of days and probably got the information he desired and thought there was no use in meeting with the people of Stevenson. . . No excuse was made whatever for his non appearance ... What kind of an unbiased report would he expect to get from men whose jobs depend on the forest reserves not being thrown open? 35

However, when the Pioneer editor later interviewed Jones, he assured him he would do everything in his power to open the reserve.

The forest reserve issue quickly brought about intertown rivalries. The Carson Journal declared there was plenty of open land around the town of Carson without opening the reserve. In response, the people from Stevenson accused Carson residents of protecting the Wind River Lumber Company from interference. Belying the Board ot Trade agenda, the Pioneer editor asked whether the people from Stevenson realized that stumpage prices would go to settlers rather than the government if the reserve were opened? And besides, the reserve handicapped the entire county. Now even the Carson Journal aided and abetted the government in

34 Rakestraw, "History," 261.

35 Pioneer, 3. 10 October 1912. 
stealing "the vast empire of Skamania County... in order to give a bunch of forest rangers a job. $" 36$

\section{The Forest Service Takes Hold}

Did the lands desired by the Board of Trade possess agricultural potential? By no means was it a clear-cut case. When the first timber sale to the Wind River Lumber Company ended, the Forest Service immediately planned another, despite the lumber company's complaints over the price of stumpage. The company did not want to pay more than $\$ 1.50$ for stumpage. Stabler insisted on $\$ 1.75-\$ 2.00$ minimum. In 1910, the Forest Supervisor assured the District Forester that another sale would take place within the next couple of years for two reasons. First, the Service had a large body of timber to sell, and secondly the company "all-but must have" timber from the National Forest because its private holdings would only keep the Cascade Locks mill operating for approximately three years. Regular and sustained annual income into the county treasury provided another reason for ensuring a sale. Stabler pointed out that overcoming ill feeling in the county:

$\ldots$ is decidedly in the interest of the Service and the country at large. . . because it has a very close relationship to the Forest fire question. Bad feeling toward the Service results in the shortsighted belief that if the entire forest burns up we 'the people' have nothing to lose. In this as in so may other things 'the people' can be made to understand by means of the almighty dollar so I consider that the receipts of a yearly school and road

36 Pioneer, 14 September 1911. 
fund from the Service will be a leaven that will work for good among the people of Skamania County." 37

Stabler determined the timber company would rely on National Forest timber for a very long time in order to cut the 25 million board feet per year the Cascade Locks mill could handle. He ordered a survey of the land, and a 2,500 acre timber sale went through in 1912. While parts of the sale area were "exceedingly rough," over half of it was in the "smooth river bottom land," and would not be difficult to log. The soil report determined the forest soil was similar to the soil near the Columbia River communities. In neither case was it particularly fertile, but depending on the topography some crops grew, and nuts and apples were particularly promising. A month before heading to Washington D.C. in March of 1912, Stabler examined the area of the proposed timber sale to the Wind River Lumber Company. He described the valley's soil as:

.... deep, fresh, sandy loam, varying from almost pure sand and gravel in places to a dry, porous clay in others, and in depth it ranges from very deep to shallow. It is fertile, well drained, and bears evidence of being well adapted for the growth of Douglas fir.

As for the agricultural potential of the soil, it was "problematic":

Some of the land, notably the bottoms, could be farmed to advantage, and the climate and soil are not ill adapted to fruit growing. The agricultural possibilities of the area resolves itself into a personal opinion in the mind of each investigator and it is believed by the present writer that the area should remain closed to settlement until high agricultural possibilities are proven by the successful tillage of the adjoining alienated lands, and in the

${ }^{37}$ H.O. Stabler to District Forester, November 14, 1910, 7. 
meantime the tract could be put to excellent use as an experimental and demonstration area for silvicultural practices. ${ }^{38}$

Clearly, thought Stabler, the Forest Service could make the best use of the Wind River Valley. The fire-fighting capabilities of the Forest Service, the Wind River Nursery, the attainment of school and road funds by Skamania County, and establishing a Forest Experiment Station would provide jobs, protection, and bolster the economy, hastening community support of the National Forest.

\section{The Community and the Forest}

By 1912, the Wind River Nursery had been firmly established, providing jobs for locals and bringing rangers to the region. Roland L. Cline joined the "Hemlock Gang," of Eilert and Chris Skaar, Fritz Sethe, Harry DeVoe, and those like Harvey Lickel who worked temporarily in the Wind River District. Cline first became a Forest Guard on a temporary contract for $\$ 900$ a year. He took an oath of office and reported for duty to the District Forester and Columbia Supervisor in Portland. By February, Cline had replaced Miner for one year with an annual $\$ 1,000$ salary. After a probationary period, Cline obtained an "absolute" position, working at the nursery until 1920 .

The nursery kept rangers and locals busy. Despite early failures, the nursery's rated capacity increased to one and one-half million trees yearly in 1912. Work typically started in the latter part of March and lasted for about two months,

38 H.O. Stabler, "Report on Examination," Gifford Pinchot National Forest Headquarters, 
and the nursery soon exhibited its own community character. Rangers and laborers built a mess house and planted a Norway Spruce hedge along Chapman Avenue, so named for the District Forester in 1910. Ranger work in 1912 consisted of constructing the Overland Trail and telephone line, and a cabin at Hemlock. That year, Stabler determined the following men would work through October: Fritz Sethe, Eilert Skaar, Dan Lewis, Axel Erickson, Charles Ross, Claude Wetherell, Alex Simpson, and Jas. Hutchings. The cook, Marshall, should be retained through October, but the packer would be let go. As the rangers waited that fall for word from Senator Jones regarding elimination of lands from the forest reserve, they hauled hay and lumber and attempted to finish the new house at Hemlock. 39 In 1913, the Forest Service established a Forest Experiment Station at Hemlock similar to those throughout the nation. The duty of the Experiment Station was to carry on "... experiments and studies leading to a full and exact knowledge of American silviculture, to the most economic utilization of the products of the forest, and to a fuller appreciation of the indirect benefits of the forest." In order to develop a regional scientific basis for forest policy, each station would deal with problems peculiar to the area. Thorton T. Munger of Silvics, the tree-growing department of the Forest Service, identified the Wind River Valley as

Vancouver, Washington, File 2400-10, WRLC, Columbia Sales (17 February 1912), 5-6.

39 Andrews interview, 5; Appointment Sheet, 12 June, File K, Appointment Sheet, 6 September 1912, File 5014, Gifford Pinchot National Forest, Wind River Training Center; Timeline, File 5016; Acting Forest Supervisor M.E. James to H.O. Stabler, September 4, 1912, Memo for Mr. Sethe from Stabler, Hemlock, Sept. 15, 1912, Memo for Mr. Cline from H.O. Stabler, Sept 15, 1912, Gifford Pinchot National Forest, Wind River Training Center, H\&S file. 
an area that could address regional complexity. The valley's transitional location on the Willamette Meridian placed it in the midst of seven district timber areas, each with distinct problems. But the most pressing was artifical reproduction of Douglas fir. ${ }^{40}$ According to Rakestraw:

The Wind River Valley had several assets. It had a climate typical of the Douglas fir; not so humid as the coast or the Snoqualmie areas, but more moist than the Santiam or Cascade forests. The area was accessible, eleven miles by road from Carson, which was fifty-eight miles by rail from Portland. Its location in the center of the Yacolt Burn made it handy for fir studies of all kinds of reproduction, at all altitudes and in all varieties of soil. In addition there were other silvical studies that could be made in the area, such as natural reproduction in the 1902 burn; studies of 75-90 year old second growth Douglas fir, and test plots of various kinds. ${ }^{41}$

With the experiment station established, work continued at Hemlock with Julius V. Hofmann in charge. Temporary laborers hired by Mr. Cline worked at both the nursery and the experiment station. That year the Forest Service recruited men from Portland to work at Hemlock. The men traveled on the North Bank Railroad to Carson and either walked or took a wagon to the ranger station, where for between six weeks and two months they received $\$ 2.50$ a day and paid .60 daily for board. Forest Officers at Hemlock remained busy during wintertime with administrative work, clearing land for nursery and experiment stations, cutting wood, cleaning seed shipped from other forests, making seed tests, completing

40 Rakestraw, "History," 254-255.

41 Rakestraw, "History," 256. 
sewer systems, installing fixtures, conducting general repairs, preparing for the following spring, and preparing for a bright future at the nursery. 42

In the following years, the Forest Service became an integral part of the local and regional community, hiring students from the Oregon Agricultural College, locals, and recruiting people from around the region for temporary work at the nursery. In 1915, the Forest Service pack train participated in the Portland Rose Festival Parade. Chris Skaar took six road mules to Portland, while Eilert Skaar did the scaling for timber sales during his absence. The scaling performed by the Skaars, who lived at the Hemlock Ranger Station and worked for the Forest Service in one capacity or another for years, was all for Wind River Lumber Company sales. The Forest Service and the Wind River Lumber Company negotiated the terms of the company's second large-scale timber purchase on the same day Stabler completed his report on agricultural lands in the Wind River Valley, February 17, 1912. The following year, the lumber company built a railroad into the upper valley to access timber along 1,000 acres of flat river bottom adjacent to the Wind River, and 1,500 acres of mountainside.

42 Acting District Forester, C.S. Judd to to Forest Supervisor Cohoon, April 4, 1914, Gifford Pinchot National Forest, Wind River Training Center, File 5006; Acting Forest Supervisor Arthur R. Wilcox to recruits, April 3, 1913, File SP, Correspondence, File S, Assistant District Forester F.E. Ames to Forest Supervisor October 11, 1915, File S, Gifford Pinchot National Forest, Wind River Training Center, Columbia - Nurseries, Wind River. 


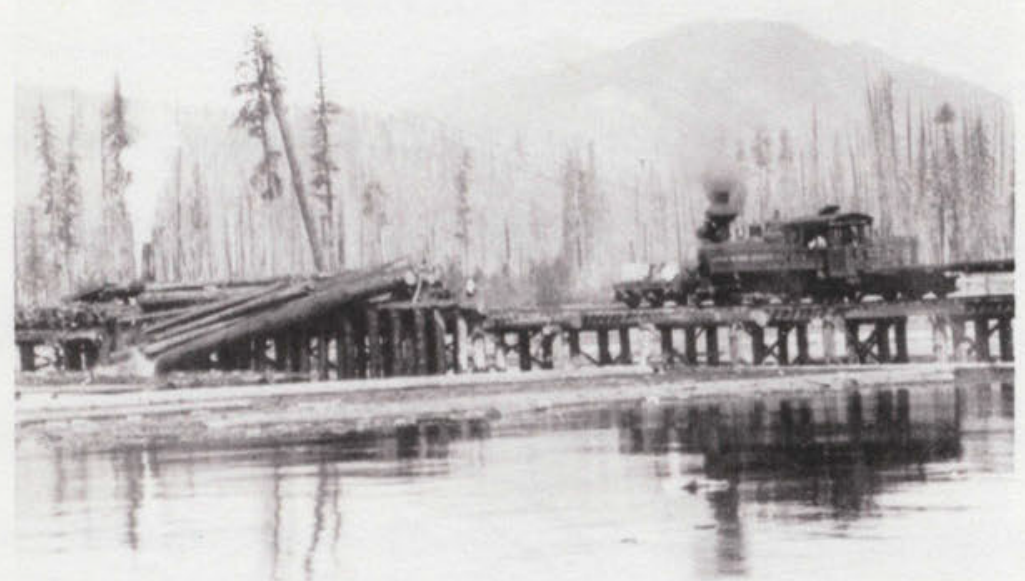

Figure 15: Wind River Lumber Company Railroad, ca. 1913-1925. Photo courtesy Gifford Pinchot National Forest

William Christensen had a stroke in 1913, and within the year the Skamania County Board of Trade disappeared from the local newspaper. By June 1914, the Wind River Lumber Company employed 120 men, put out 900,000 board feet weekly, and extended the railroad line into the areas previously desired by the county. Three steam-powered yarding donkeys and other new technologies facilitated the logging output. Logs came by rail to a $\log$ pond near Camp 8 . Once in the pond, men sawed the logs into 16-40 foot lengths with a gasoline cut-off saw, Chris or Eilert Skaar scaled them. After several hundred thousand board feet accumulated in the pond, the men opened the gates of the splash dam, driving the logs down the Wind. The railroad line continued to expand as the Forest Service made extensions to the February 17,1912 sale, with railroad spurs constructed off the main line to access remote areas. 
In 1914 , his job completed, H.O. Stabler left the region and nearby residents named the town next to the ranger station for him. The town of Stabler had a schoolhouse attended together by rangers' children, homesteaders' children, and loggers' children. The following year, the new Forest Supervisor, Anson E. Cohoon ordered a large sign -"COLUMBIA NATIONAL FOREST" - painted and sent to Hemlock for posting. He directed rangers to place the sign at Wigal corner, facing the road from the town, on two round cedar posts painted white, about nine or ten feet above the ground . . “ By 1925, additional main railroad lines extended as far north as Paradise Creek, and the Wind River Lumber Company had logged the federal lands of the valley for nearly twenty years. In July 1925, an extensive fire wiped the company out, destroying five donkey engines, the last three miles of railroad line, other equipment, and four and a half million board feet of felled timber. The huge loss prompted the company to abandon its most recent 27 million board feet sale, and it pulled out of the Wind River Valley. 43

Both the newly created "National Forests" and the Forest "Service" implied rational use rather than reserving resources. ${ }^{44}$ This, writes Harold Pinkett, typified Pinchot's consistent attitude "toward the purpose for which he deemed forests are

43 Acting District Forester F.E. Ames to District Forester Cohoon, March 7, 1914, Forest Supervisor, File S, Gifford Pinchot National Forest, Wind River Training Center, Columbia Nurseries, Wind River; Anson Cohoon to Forest Ranger Cline, June 3, 1915, Supervision file, Gifford Pinchot National Forest, Wind River Training Center, Columbia - Nurseries, Wind River; Jamie Tolfree, "History of the Wind River Lumber Company in the Upper Wind River Valley, Part 2" Skamania County Heritage, 13, No. 4, (March 1985), 4; Letter from Cohoon to Forest Ranger Cline, April 19, 1915, Supervision file.

44 Breaking New Ground, 257; Pinkett, Gifford Pinchot, 59. 
managed - to secure the conservation of an essential natural resource in the national interest." Such a statement sounds boosterish and altruistic, yet in many respects it was true. At heart Pinchot was a forester and a woodsman, and throughout Breaking New Ground he is his own best promoter as an advocate of poor man's politics. He was also a scientist who came from an elite background. Two things, according to Pinchot, would conserve the forests for the future, scientific forestry and industry backing. Just as Pinchot thought he could develop a practical forestry for the future, he felt he could create an administrative policy that would satisfy all interested parties, from Frederick Weyerhauser to William Christensen.

The year that William Christensen had a stroke and the Board of Trade disappeared from the local newspaper, 1913, Skamania County residents participated in the Clark County Fair rather than holding their own. In 1914, a Bureau of Soils report assessing Panther Creek in the Wind River Valley designated nearly 900 acres potentially agricultural. However, only 60 acres would be listed for homesteads. Another 58 acres went to the Forest Service for ranger stations. Since the Wind River logging railroad needed a right of way through the valley, listing homestead lands would effectively "bottle up" 13,520.6 acres of ripe timber "only waiting for the exploitation of more accessible tracts before it becomes marketable." The Forest Service withheld the remaining agricultural land "to 
insure economic logging and complete utilization of the valley." The Memorial and Petition to Congress from the Board of Trade had failed. 45

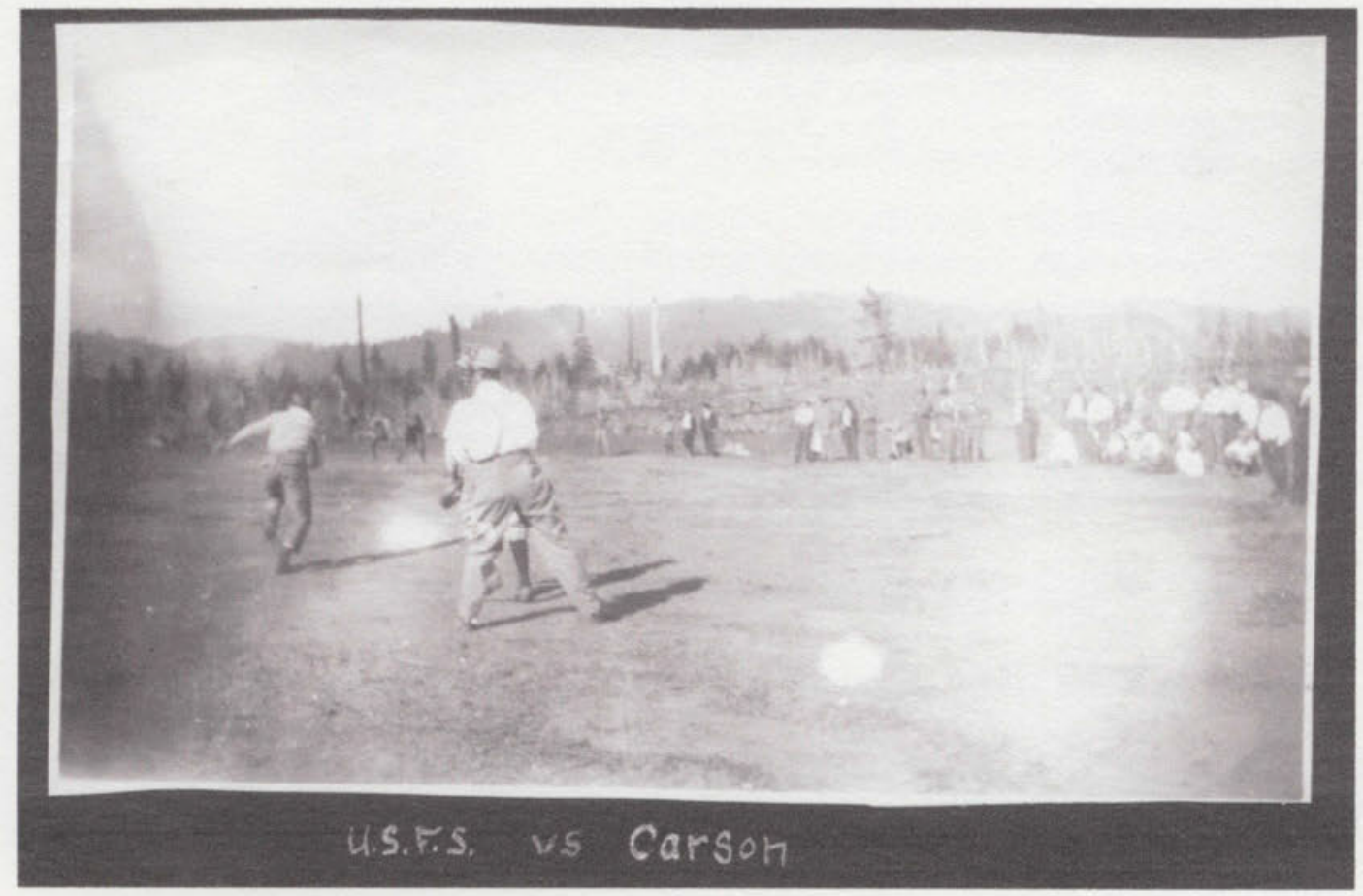

Figure 16: Forest Service/community competition. U.S. Forest Service vs. Carson. Photo courtesy Gifford Pinchot National Forest

45 W.G. Hastings, "Land Classification Report on Panther Creek Project," March 1914, Gifford Pinchot National Forest Headquarters, Vancouver, Washington. 


\section{CONCLUSION}

Opposition to the reserve in southern Skamania County was important for a number of reasons. The contest over the Wind River Valley is an example of the way in which belief systems can shape behavior and consequently impact the material world. Ideals of Jeffersonian democracy, with private land ownership assuring liberty, dignity and economic security, clashed first with an existing belief system and pattern of common resource use and then with an imposed public conservation ethic in the Wind River Valley. Visions of the landscape's utility and value shifted dramatically during the latter nineteenth century as an increasingly unrestrained market economy and a solidifying scientific ethic impacted human behavior. In Skamania County the forest provided a catalyst for creating the Board of Public Improvement, an organization reflecting community character while promoting the primacy of private property. Renaming itself the Board of Trade more accurately reflected the principles underlying its formation.

Congressional debates over individual access to public forests raged near the turn of the century. These debates stemmed from opposition by American citizens to locking up resources for the benefit of big business. ${ }^{1}$ Although elimination efforts in Skamania County failed, similar opposing forces throughout the West led to the restoration of over 10 million acres to the public domain between 1908 and 1912. Most importantly for Skamania County, opposition to the

\footnotetext{
${ }^{1}$ Paul Hirt. A Conspiracy of Optimism: Management of the National Forests Since World War Two (Lincoln: University of Nebraska Press, 1994), xvii.
} 
reserve highlights the roots of federal dependence in a place deemed by the $1980 \mathrm{~s}$ the most timber dependent in the state. As the Forest Service asserted its authority at the turn of the century "for the greatest good," community members driven by agrarian ideals, the free market, and the potential for community prosperity, unrealistically extended their vision. The value of the Wind River Valley to members of the Board of Trade was shaped more by ideas of what should be, and a perceived self-determination without government interference, than it was by the landscape. As Stabler put it, "No 100,000 acres of agricultural land" was available in the valley. Neither was timber the only crop that could be grown. ${ }^{2}$

Contests between public and private control over land and resources have historically influenced Columbia Gorge communities. Native people accessed resources through family ties and usufruct rights, trading resources up and down the river for subsistence and to develop social connections, but not for a capitalist accumulation of wealth. A clear distinction exists between the native accumulation of social wealth, such as slaves, art, and prestige, and the Euro-American commodification of goods wrested from the natural environment. Early non-Indian settlers immediately brought a market economy to the banks of the Columbia, and quickly imposed a built landscape. Settlers saw opportunities to create new lives and thriving communities in the midst of regions of resource abundance, and their differing views of nature caused struggles for control of the land, its resources, and its meanings. Patterns of work, economy, and forest use shifted as later settlers

\footnotetext{
${ }^{2}$ Congressional Record, 48, 7 (May 16, 1912).
} 
recognized the potential of the forested lands to the north. By the time the North Bank Railroad plied the north shore in 1907, the system of forest administration created during the Progressive Conservation Era had facilitated development of extractive industry as the county's economic foundation.

Yet some residents, either truly grounded in agrarian ethics or using agrarian arguments in their own self-interest, boisterously maintained an alternative view of the landscape. To the members of the Skamania County Board of Trade, agriculture and property taxes seemed the foundation of community building. They viewed the forested lands as a means of stretching their gardenic visions and obtaining revenue. Like the native inhabitants, early settlers used the forest for subsistence, making most everything from wood and harvesting numerous forest products, from berries to medicinals. Indians at the Cascades traded beargrass for wapato dowriver, and early settlers sold cordwood to those in arid communities upriver. Some viewed the forests as a main source of income, building sawmills and providing jobs. And still others viewed the forestlands as potential gardens. First build a home, cut the timber and sell it, then sow and reap the bounty of cutover lands. This was the dream of the American farmer, a dream propelled by government rhetoric, myth, and flawed categories.

In many ways, the government used the same process that artificially bounded the land to impose false categories on native people. Arbitrary geographic divisions between Oregon and Washington sent native people to the coast at Grande Ronde or to the east side of the mountains to Yakama, outside of their 
traditional homeland. Although they retained rights to fish and gather at usual and accustomed sites, fundamental flaws existed in the ways that the U.S. government grouped native people. Many groups comprised the river people of the Cascades, with the Chinookan Gahl'xishachk, "people of the rapids," most prominent in the region where Beacon Rock and Stevenson now stand. ${ }^{3}$ However, delineating tribal boundaries between groups was difficult. In some ways the transitory zone at the edge of the Columbia and into the forests of the Cascades hosted a social manifestation of the ecotone. The Klickitat, Yakama, Taitnapum, Wishram, Wasco, White Salmon, and Cascade or Watlala people all used the resource dense river and forest in this region, one of the most food-rich areas of the Northwest. ${ }^{4}$ The experience of the Cascades, a group now deemed extinct by the federal government, demonstrates just how tenuous such arbitrary social and geographic distinctions are. Today because of the uninformed categorization of groups, those of Cascades descent must essentially deny their own heritage. In order to enroll on one of the reservations, they must claim they are Yakama or Grande Ronde, or some other "recognized" group, thus becoming part of the imposed category in order to be acknowledged. In 2001, the Clinton administration recognized the Chinook as a tribe. In 2002, two days after inviting Chinook tribal members to dine at the White House, the Bush administration rescinded recognition. The administration officially declared the tribe "extinct," although many Chinook descendants are members of reservations - Shoalwater Bay, Quinalt, Grande

\footnotetext{
${ }^{3}$ Chuck Williams, Bridge of the Gods, Mountains of Fire, 50.

${ }^{4}$ McClure and Mack, "Data Recovery Excavations," 15.
} 
Ronde, and Chehalis. According to the Bureau of Indian Affairs in July 2002, "the Chinook petitioner...consists predominantly of non-reservation Chinook descendants." Because they had not continuously functioned as a political entity, the government decided they no longer existed. ${ }^{5}$

Such paradoxical outcomes applied to public land laws as well. Although the law seemingly upheld dreams of the independent American, rampant land fraud through the last half of the nineteenth century produced contradictory consequences. In many ways the land laws locked up resources while opening them to corruption. For some, attaining western prosperity meant making use of every possible avenue, legal or illegal. Railroads, timber magnates, and a few dishonest individuals like "Cascade Bill," benefited from public land disposal policies while the true family farmer often encountered disappointing realities. Crops grown in cutover lands at high altitudes didn't do as well as those on the river bottoms, and few could eke out a living without alternate sources of income such as fishing, selling cordwood, or working in a sawmill.

True economic prosperity came in relation to the landscape, the national economy, and American ethics. Men like Felix Atwell found success by bringing forest and river together with a toolkit, because the river tied the land to the outside world and made it possible to benefit from forest resources. Until 1897 when the government imposed a new set of boundaries through the Mount Rainier Forest

\footnotetext{
${ }^{5}$ Lewis Kamb, "Tribe that aided Lewis and Clark now seeks help," Seattle Post Intelligencer 2 June 2003, from http://www.seattlepi.nwsource.com/local/124653 chinook02.html [accessed January 5 , 2004]; Bureau of Indian Affairs Press Release, "Final Determination Declines Chinook Recognition," 5 July 2002, from http://www.doi.gov/news/chinook.htm [accessed January 5, 2004].
} 
Reserve, settlers on the north shore of the Columbia saw opportunity all around, in rivers, the bubbling hot springs, and especially in the forest. Imposing a conservationist ethic on the landscape changed those dreams.

A number of issues lie at the core of the battle over meaning at the Cascades and in the Wind River Valley - private versus public property, market capitalism, and an agrarian ethic. These have been the foundation of a private property-owning independent citizenry. As Americans moved west, at times the landscape itself seemed insignificant, for they could impose their own realities upon it. With a plot of land, an axe and a plow, a man could carve a living from a piece of rock, or so it seemed to the members of the Board of Trade in Skamania County. Turn of the century Pacific Northwest immigrants held deeply embedded dreams about what constituted the good life, and private access to resources was key. Ironically, although locking up the forest seemed "a hard blow," prompting some to consider disbanding the county, government projects in Skamania County sustained development. $^{6}$ In the 1890 s, building Cascade Locks on the Columbia's south bank to open river passage kept people employed for years. The 1907 North Bank Railroad provided jobs, using National Forest timber to produce the ties. If a man from Skamania County had not gone to fight in Europe during World War I, then he likely worked at the Wind River Lumber Company's mill at Cascade Locks. The Pacific Northwest harvested more than 143 mbf of Sitka Spruce, Douglas Fir and Cedar for airplane production during the war, of which nearly half, $66.5 \mathrm{mbf}$,

\footnotetext{
6 "Henry Metzger Writes About Early Days in the County," Pioneer, June 1948.
} 
came from private sawmills. ${ }^{7}$ By 1933 , the largest government projects to reach the state, construction of Bonneville Dam, and the Civilian Conservation Corps, brought people to work from all around the nation.

Public lands management lies at the core of the relationship between county and federal government, and affects community identity. The first forest reserves, created in 1891 , completely prohibited the individual from access to forest resources. With the 1897 Organic Act, settlers could access forest resources for private use, and by 1905 lumber companies could access forest resources for timber. U.S. Forest Service management shifted meanings of the landscape in the southern portion of the forest. Some settlers saw dual opportunity through timber harvest, cordwood production, and agricultural subsistence. The Forest Service viewed the landscape as a key to economic self-sustenance. Timber provided one economic avenue for the Forest Service. The landscape in Township 4 where Elias Wigal sited the ranger station, provided another. This land, valued by the Board of Trade for agriculture, became valuable to H.O. Stabler for placement of the Wind River Nursery and the Forest Experimental Station.

Ironically, Forest Service employment contributed to community identity as the work patterns of the twentieth century became established in the county. Men worked as loggers, in sawmills and construction and women worked on the periphery, cooking in logging camps, and running hotels and restaurants. Even

\footnotetext{
${ }^{7}$ Gail Evans and Gerald Williams, Appendix D in "Over Here, Over Here: The Army's Spruce Production Division During 'The War To End All Wars,"' Revised version of a paper presented at the Washington Military History Conference (Camp Murray, Washington, March 30, 1984.

Revised June 1998).
} 
children helped with mens' work. Phoebe Yeo recalled, "I know I handled sticks of cordwood that weighed more than I did." Phoebe Yeo's father used a flume to float cordwood down the river, and she and her brother Bruce took care of it. Then, when the railroad was built, they loaded boxcars and sent the cordwood as far as Spokane. The North Bank Railroad gave the county a "lift," claimed Henry Metzger in 1948 and the county prospered from that point onward. ${ }^{8}$ Carson homesteaders like Elias Wigal and Eilert Skaar developed long-term family connections with the Forest Service, and for many years the Wind River Nursery provided temporary seasonal employment to many people around the region.

Prior to the first timber sale on the Columbia Forest Reserve, there were numerous small mills taking a lot of timber off the land. Forest Service policies, shaped by Gifford Pinchot and many others, upheld sales to companies like the Wind River Lumber Company because they had the means to extract large volumes of timber, which could then be replaced through scientific forestry methods. Pinchot's contribution lies mainly in his dogged efforts to create a utilitarian system of administration that would allow access to public resources. According to Pinchot, these public resources should serve two purposes - providing the industrial infrastructure for national growth and allowing the individual user to meet his or her needs. Unlike Aldo Leopold who defined a land ethic in the 1940s based on a biotic, land-based ecosystem perspective, or John Muir, who privileged the spiritual value of the landscape above all else, Gifford Pinchot took an

\footnotetext{
${ }^{8} \mathrm{Ibid}$; Phoebe Yeo interview, 7-8.
} 
anthropocentric approach to land management. For Leopold, "a thing is right if it preserves the integrity, stability, and beauty of a biotic system. It is wrong when it tends otherwise." Ironically, Pinchot's moral goal was to prevent monopoly of natural resources, but according to Samuel Hays, "conservation, above all was a scientific movement. ... It is from the vantage point of applied science, rather than of democratic protest, that one must understand the historic role of the conservation movement."

What Pinchot intended, in keeping with his training and values, was to farm trees and study forests. Technicians rather than legislators should deal with resource issues. As a Theodore Roosevelt conservationist and, most importantly as a forester, Pinchot felt that he knew better than anyone what was good for the forests of the people of the United States. As Harold Langille succinctly put it: "The controversy was not between the residents affected. It was bitter, outspoken opposition to a governmental policy that contemplated curtailment of the timehonored privilege of grab and take." ${ }^{10}$ From 1906 until 1913, as Pinchot's approach to scientifc forestry became entrenched and the lumber industry gained legal access to forestlands, Skamania County entered a state's rights controversy that in some form continues today. The Board of Trade called on Senator Wesley Jones because he espoused the belief throughout his career that the "little man"

\footnotetext{
${ }^{9}$ Aldo Leopold, "Aldo Leopold Proposes a Land Ethic," in Carolyn Merchant, Major Problems in American Environmental History: Documents and Essays (Berkeley, CA: University of California Press, 1993), 458; Samuel Hays, "Conservation as Efficiency," reprinted by permission of the publishers from Conservation and the Gospel of Efficiency by Samuel P. Hays, Cambridge, Mass: Harvard University Press, 1959, in Merchant, Major Problems, 359.

${ }^{10}$ Langille, "Mostly Division R Days," 308.
} 
should benefit from the resources held by the federal government. “... conservation without development had no substantial reason for existence." Jones agreed with Governor Hay and other westerners, that the individual states should control their own resources, "but like states-righters from 1789 on, Jones felt the federal government should help the states whenever called upon." "11

Pinchot did not intend to uphold the corporate status quo. However, by World War II, bolstered by new technologies such as chainsaws and trucks, with roads to get the wood out, the outcome of scientific forestry was the annual harvest of billions of board feet of timber "to fuel an expanding economy."12 From 1906 until 1925, only the Wind River Lumber Company harvested large amounts of timber from federal lands in the Wind River Valley. Smaller operators also cut timber on an ongoing basis, but not at the same scale. In 1948, the Forest Service began intensive management of commercial forestlands for high yields of timber, wildlife, fish, water, and recreation. By mid-century, Skamania County received $\$ 108,350$ from timber revenues for school and road funds, prompting Carson resident Henry Metzger to declare:

... we should now be able to "Balance the Budget."

On account of the money we now receive from timber sales in the Forest Reserve (and will probably receive for many years to come in greater or lesser amounts) we could, and should, have a reasonable tax rate in our county. That card would be a good drawing card to attract industry and homeseekers to this area. ${ }^{13}$

\footnotetext{
${ }^{11}$ Forth, "Wesley Jones," 158.

${ }^{12}$ Watershed Analysis, III-3-15.

13 "Henry Metzger," Pioneer, June, 1948.
} 
During the $1950 \mathrm{~s}$ timber yields escalated nationally from 3.5 billion board feet to 9.3 billion board feet, averaging 10-15 billion board feet for the next thirty years. Forest policy changed in the 1960s with the Multiple Use Sustained Yield Act, initiated by protests regarding the visual and aesthetic effects of clearcut logging, even as allowable cutting rates rose. Forest Service policy under the Multiple Use Sustained Yield Act called for raising mitigating programs related to timber sales at the same time it called for a seventy-five percent increase in timber sales. The maximum allowable cut soon became the minimum sustained yield goal. ${ }^{14}$ From 1950 to 1993 the Wind River Ranger District sold between 40 million and 100 million board feet of timber annually:

The preferred method was regeneration patch clearcuts followed by artificial reforestation by planting. The objective was to produce fast growing stands that maximized the production of saw logs. By 1995 over 32,000 acres of mature forest within the Wind River watershed had been regenerated and converted to early-successional plantations. ${ }^{15}$

Where once fire shaped the landscape, clearcutting reshaped it into even-aged stands of early to mid-successional forests creating single-species monocultures with little species diversity. ${ }^{16}$

As scientists, legislators, and the public learned more about ecosystems a political movement took hold in the United States. Major pieces of environmental legislation passed through the last third of the twentieth century affected forest management including the 1969 National Environmental Policy Act (NEPA), the

\footnotetext{
${ }^{14}$ Hirt, Conspiracy of Optimism, 131-132, 195.

${ }^{15}$ Watershed Analysis, III-3-15.

16 Watershed Analysis, III-3-16.
} 
1972 Clean Water and the 1973 Endangered Species Acts, and the 1976 National Forest Management Act (NFMA). These pieces of legislation mandated clean water, citizen input, and plans to manage forests for uses other than timber sales, making habitat health a priority. By the end of the 1980 s in the Pacific Northwest, the northern spotted owl had become symbolic of overcutting and habitat loss. As environmental historian Paul Hirt points out:

After decades of unbalanced, commodity-oriented management. . . ecosystem deterioration in the Northwest reached calamity proportions - or so claimed environmentalists and many scientists. Conservation groups accelerated their legal challenges to Forest Service management plans and timber sales. They had been suing for decades, but in the late 1980 s they started winning big. These 'wins' in fact indicated that the federal judicial branch found substantial merit in environmentalists' claims that the Forest Service had been systematically and deliberately violating environmental protection laws to get the cut out. ${ }^{17}$

In 1989, a federal judge told the Forest Service "to go back to square one and draw up a 'scientifically credible' plan to protect minimum viable populations of native wildlife as the National Forest Management Act requires."18 In 1990, the Gifford Pinchot National Forest published its Forest Plan developed under NEPA and NFMA. In 1993, President Clinton held a forest conference in Portland, Oregon. One outcome was reduced timber harvests on the Gifford Pinchot and the closure of some of the last sawmills in southern Skamania County, including Stevenson Co-Ply. In 2004, only one sawmill operated in the county, the Wilkins, Kaiser, \&

\footnotetext{
${ }^{17}$ Hirt, Conspiracy of Optimism, 288-289.

${ }^{18}$ Hirt, Conspiracy of Optimism, 289.
} 
Olsen, Inc. (WKO) mill in Carson employed 125 people. The High Cascade veneer mill in Home Valley employed an additional twenty-five. ${ }^{19}$

As in many western communities, a paradoxical relationship with the federal government has shaped values and identity in Skamania County. Because most of the county is federally managed, ideals of Jeffersonian democracy, autonomy, and civil liberties in Skamania, have government dependence as their very foundation. County residents railed against the designation of forest reserves in the county at the turn of the century. With the implementation of the National Scenic Area Act of 1986, nearly the entire county is now under the influence of federal agency management to some degree. During the last forty years of the twentieth century, urban in-migration, national recessions and environmental legislation seriously affected logging communities in Skamania County. With the 1993 closure of Stevenson Co-Ply, an era of perceived autonomy ended. Skamania Lodge, built through funds provided by the Scenic Area Act, became the county's largest employer and the wood products industries turned to manufacturing sailboards, using the internationally known gorge winds to derive a living.

In 1997, because of diminished cuts, the Wind River Nursery closed after operating as a pioneer in forest nursery practices for nearly ninety years. The need for reforestation no longer existed, because environmental legislation and consequent lawsuits prohibited clearcuts in the Gifford Pinchot National Forest. Only private lands are now subject to clearcutting. In 1998, Skamania County

\footnotetext{
${ }^{19}$ Personal Communication, Richard McClure, February 16, 2004.
} 
agreed to convey all "right, title and interest" to 120 acres of land on Table Mountain in the Columbia River Gorge National Scenic Area. The Forest Service would also receive thirty acres on Wind Mountain and a small easement in the Mt. St. Helens area. In exchange, the Forest Service agreed to convey to the county "the Wind River Nursery Site lands and all interests therein." The conveyance to the nursery site took place in February 2002, when the Forest Service signed title to 187.5 acres and eighteen buildings over to Skamania County.

The events in the Wind River Valley and on the Columbia's north bank provide the context for a deeper understanding of place. Yi-Fu Tuan describes place as a reality to be understood from the perspective of those who have given it meaning. Meaning in Skamania County was assigned by a variety of actors. The physical and social landscape of the gorge contributed to the layering of human experience and "changeability" of place. A different sense of place emerges for native people and early emigrants than for nineteenth century loggers or early twentieth century businessmen and Forest Service employees. The former lived in an animated world. The latter rationalized the world through objective structures in an attempt to maximize the general welfare and productivity. ${ }^{20}$

We cannot ask those who have historically assigned meaning to place to tell us about it. We can only try to tease out the threads of meaning that exist in the relationship between place and culture, to gain a historic sense of place. By drawing out the haptic sense of place, one can imagine what it feels like to live in a

\footnotetext{
${ }^{20}$ Entrikin, Betweenness of Place, 8, 10.
} 
particular time and space, and how place has been recreated. The haptic sense ranges from the sounds and smells associated with the non-human environment, to the sense of place one has when theoretical boundaries have been established, for example in J.W. Hill's "limited" territory. The boundaries created by the Forest Service and resisted by the Board of Trade were mental constructs, and yet they had specific outcomes. As Entrikin puts it: "Places take on meanings of events and objects that occur there, and their descriptions are fused with human goals, values, and intentions. Places and their contents are seen as wholes."21 By listening carefully for the emotive quality of language, one can understand how perception can be deliberately manipulated and less consciously absorbed. By asking questions about how the material world is used and perceived, it may be possible to mediate the tensions between an objective scientific reality and an existential subjective reality. Thus it is possible to better understand community identity through the layers of meaning encapsulated in a synthesis between time and space. As Dan Flores explains, "Human cultures alter their places to shape them in accordance with their ideological visions, and in turn cultures are shaped by the power of their places." 22

Through the kinds of questions of perception, symbol, and meaning of place posed for environmental historians by William Lang, it is possible, as he points out, to better understand human actions and reactions, and their relationship to environmental change. Both forest and river have changed drastically since the

\footnotetext{
${ }^{21}$ Entrikin, The Betweenness of Place, 11.

${ }^{22}$ Flores, "Argument," 42.
} 
mid-nineteenth century and history is often fraught with ironic twists. As of 2004, Skamania County had not determined how it would use the Wind River Nursery site. Some discussed placing a housing development where once rangers and community members planted the fir tree seedlings that created a monoculture of Douglas Fir around the Pacific Northwest. The land exchange granted the county the most desirable property sought by the Board of Trade in 1902 and 1911. In return, the lands on Table Mountain, the remaining bare-faced half of the Bridge of the Gods, became part of the Gifford Pinchot National Forest. ${ }^{23}$

\footnotetext{
${ }^{23}$ United States Congress, House, Congressional Record (October 19, 1998) [from the Congressional Record online via GPO access, wais.access.gpo.gov]; Lang, "Sense of Place," 85.
} 


\section{BIBLIOGRAPHY}

\section{Primary Sources and Unpublished Materials}

Andrews, Lynn. "An Interview with Lynn Andrews." Interview by Rick McClure and Cheryl Mack, 17 June 1999, transcript. Heritage Program, Gifford Pinchot National Forest, Trout Lake, Washington.

Belyea, Barbara, ed. Columbia Journals: David Thompson. Canada: McGill-Queen's University Press, 1994.

Brown, Nelson Courtland. Forest Products, Their Manufacture And Use: Embracing the Principal Commercial Features In the Production, Manufacture, And Utilization Of The Most Important Forest Products Other Than Lumber, In The United States. New York: John Wiley \& Sons, Inc., London: Chapman \& Hall, Limited, 1919.

Bunnell, Clarence Orvel. Legends of the Klickitats: A Klickitat Version of the Story of the Bridge of the Gods. Portland, OR: Metropolitan Press, 1935.

Dart, Anson. "Letter from Anson Dart to the Bureau of Indian Affairs in 1851." Reprinted in McChesney, et. al. The Rolls of Certain Indian Tribes in Washington and Oregon. Fairfield, WA: Ye Galleon Press, 1969.

Edwards, Douglas. "Advertising the 'Zone of Plenty': The Northwest Development League and the Incorporation of Regional Identity. Unpublished paper presented at the 39th Annual Conference of the Western History Association. Portland, Oregon, October 6-9, 1999.

Forest Service Files. "Columbia Boundaries - File 2400-10 - Wind River Lumber Company." Heritage Program. Gifford Pinchot National Forest Headquarters. Vancouver, Washington.

Forest Service Files. "L-Boundaries-Land Exchange - File 5027 - Homestead Claims - Wind River." Heritage Program. Gifford Pinchot National Forest Headquarters. Vancouver, Washington.

Forest Service Files. "Early Forest Service, Wind River Collection. Heritage Program. Gifford Pinchot National Forest. Wind River Training Center. Wind River Ranger Station. 
Gibbs, George. "Tribes of Western Washington and Northwestern Oregon." In Contributions to North American Ethnology. Vol. 1. U.S. Geographical \& Geological Survey of the Rocky Mountain Region (Washington: Government Printing Office, 1877): 163-208.

Harris, James G. "Skamania County." Told By the Pioneers. U.S. Works Progress Administration. Vol. 3, Washington Pioneer Project. Printed under WPA Sponsored Federal Project No. 5841, 1938, 72-74.

Iman, Louis F. "Skamania County." Told By the Pioneers. U.S. Works Progress Administration. Vol. 3, Washington Pioneer Project. Printed under WPA Sponsored Federal Project No. 5841, 1938, 68-70.

Iman, Margaret Windsor. "My Arrival in Washington in 1852." Told By the Pioneers. U.S. Works Progress Administration. Vol. 1, Washington Pioneer Project. Printed under WPA Sponsored Federal Project No. 5841, 1937.

Mack, Cheryl, ed. Elias Wigal Diaries. Heritage Program. Gifford Pinchot National Forest Headquarters. Trout Lake, Washington, January 2004. [Draft Transcript].

Moulton, Gary E., ed. The Journals of the Lewis \& Clark Expedition, July 28-Nov. 1, 1805. Vol. 5. Lincoln: University of Nebraska Press, 1988.

. The Journals of the Lewis \& Clark Expedition, March 23-June 9, 1806. Vol. 7. Lincoln: University of Nebraska Press, 1991.

Pinchot, Gifford. Breaking New Ground. New York: Harcourt, Brace and Company, 1947.

Ramsay, Daphne Hon. Skamania County, Washington census records : 1860, 1870, 1880, 1885, 1887. 2nd ed. Clark County Genealogical Society, 1987.

Ross, Alexander. Adventures of the First Settlers on the Oregon or Columbia River. ed. with historical introduction and notes by Milo Milton Quaife New York: Citadel Press, 1969.

. Fur Hunters of the Far West. ed. Kenneth Spaulding. Norman: University of Oklahoma Press, 1956. 
Settle, Raymond. ed. The March of the Mounted Riflemen: First United States Military Expedition to travel the full length of the Oregon Trail from Fort Leavenworth to Fort Vancouver, May to October, 1849, as recorded in the journals of Major Osborne Cross and George Gibbs and the official report of Colonel Loring,. Reprint. Originally published: Glendale, CA: Arthur H. Clark Co., 1940. Lincoln: University of Nebraska Press, 1989.

Sheridan, Philip. Personal Memoirs of P.H. Sheridan. Volume 1. New York: Charles L. Webster \& Company, 1888.

Skamania County Auditor's Office Files. "Incorporated Logging Companies and Lumber Mills, Skamania County, 1850-1920.” [typescript prepared for author from auditor's files].

"Treaty between the United States and the Indians of the Willamette Valley" (10 Stats 1143, January 15 - April 10,1855). University of Washington Digital Collections, American Indian Collection.

United States. Congress. House. Committee on the Public Lands. Entry of Agricultural Lands In Forest Reserves. Report submitted by Mr. Lacey. 58th Cong., 2d sess. Report No. 2078.

. Entry of Agricultural Lands In Forest Reserves. Report submitted by Mr. Carter. 59th Cong., 1st sess. Report No. 3291.

United States Congress. Senate. Committee on Indian Affairs. A Bill Authorizing the negotiation of treaties with the Indian tribes in the Territory of Oregon, for the extinguishment of their claims to lands lying west of the Cascade mountains and for other purposes. $31^{\text {st }}$ Cong., 1st sess. S.B. 90.

United States Congress. Senate. United States Office of the Commissioner of Indian Affairs. "Report of A.P. Dennison, agent for the Indians of the northeastern district of Oregon." Report No. 94. August 1, 1858. In Report of the Commissioner of Indian Affairs (1858): 262-265. University of Washington Digital Collections, American Indian Collection.

. "Report of A. Townsend, local Agent at the White Salmon reservation." Report No. 143, June 30, 1857. In Report of the Commissioner of Indian Affairs (1857): 348-349. University of Washington Digital Collections, American Indian Collection. 
. "Report of R.H. Lansdale, agent for the Indians north of the Columbia River and east of the Cascade Mountains." Report No. 99, August 1, 1858. In Report of the Commissioner of Indian Affairs, (1858): 275-276. University of Washington Digital Collections, American Indian Collection.

. "Report of R.H. Lansdale, agent for the Klickitat, Wisham, Columbia River, Yakima and Wenatch Indians." Report No. 188, August 1, 1859. In Report of the Commissioner of Indian Affairs, (1859): 409-413. University of Washington Digital Collections, American Indian Collection.

United States Department of Agriculture, Forest Service. Gifford Pinchot, Forester. The Use Book: Regulations And Instructions For The Use Of The National Forest Reserves. Washington, G.P.O., 1906.

. Yearbook of the United States Department of Agriculture, 1906. Washington, D.C.: G.P.O., 1907.

. Yearbook of the United States Department of Agriculture, 1911. Washington, D.C.: G.P.O., 1912.

. Yearbook of the United States Department of Agriculture, 1920. Washington, D.C.: G.P.O., 1921.

United States Geological Survey. "Mount Rainier Forest Reserve, Washington." By Fred G. Plummer in $21^{\text {st }}$ Annual Report of the U.S. Geological Survey, 1899-1900. Gifford Pinchot National Forest Headquarters. Vancouver, Washington.

Williams, Chuck. "An Interview with Chuck Williams." Interview by Kathy Tucker, 26 April 2000. Interview 2773.1, transcript. Columbia Communities Oral History Collection. Oregon Historical Society. Portland, Oregon.

Yeo, Tom and Phoebe Yeo. "An Interview with Tom \& Phoebe Yeo." Interview by Ivan Donaldson. March 16, 1981. Transcript. Oral History Collection. Skamania County Historical Society, Columbia Gorge Interpretive Center. 


\section{Articles and Anthology Book Chapters}

Cox, Thomas R. "Changing Forests, Changing Needs: Using the Pacific Northwest's Westside Forests, Past and Present." In Northwest Lands, Northwest Peoples: Readings in Environmental History. Edited by Dale G. Goble and Paul W. Hirt (Seattle: University of Washington Press, 1999): 462-478.

Crumley, Carole L. "The Ecology of Conquest: Contrasting Agropastoral and Agricultural Societies' Adaptation to Climatic Change." In Historical Ecology: Cultural Knowledge and Changing Landscapes, ed. Carole L. Crumley (Santa Fe, NM: School of American Research Press, 1994): 183-201.

Engberg, Robert. "John Muir's 'Great Evils from Destruction of Forests." The Pacific Historian (Summer 1981): 10-14.

Evans, Gail and Gerald Williams. "Over Here, Over Here: The Army's Spruce Production Division During 'The War To End All Wars.'" Revised version of a paper presented at the Washington Military History Conference (Camp Murray, Washington, March 30, 1984. Revised June 1998).

Fedkiw, John. "National Forests and the Performance of the Organic Act of 1897." Forest History Today (1998): 12-17.

Flores, Dan. "Place: An Argument for Bioregional History." in Northwest Lands, Northwest People: Readings in Environmental History. ed. Dale D. Goble and Paul W. Hirt (Seattle: University of Washington Press, 1999): 31-50.

Gifford, Terry. John Muir: The Eight Wilderness Discovery Books (London and Seattle: Diadem and the Mountaineers, Seattle, 1992): Introduction.

Hays, Samuel. "Conservation as Efficiency." In Major Problems in American Environmental History. ed. Carolyn Merchant. (Lexington, Massachusetts, 1993): 358-359.

Koppes, Clayton R. "Efficiency/Equity/Esthetics: Towards a Reinterpretation of American Conservation." Environmental Review 11, 2 (Summer 1987): 127-146. 
Lang, William L. "The Sense of Place and Environmental History." In Northwest Lands, Northwest People: Readings in Environmental History. ed. Dale D. Goble and Paul W. Hirt (Seattle: University of Washington Press, 1999): 79-94.

Langille, Harold D. "Mostly Division 'R' Days: Reminiscences of the Stormy, Pioneering Days of the Forest Reserves." Oregon Historical Quarterly. 57, 4 (December 1956): 301-313.

Leopold, Aldo. "Aldo Leopold Proposes a Land Ethic, 1949." in Major Problems in American Environmental History. ed. Carolyn Merchant (Lexington, Massachusetts: D.C. Heath and Company, 1993): 454-457.

Norton, Helen H., Robert Boyd and Eugene Hunn. "The Klickitat Trail of Southcentral Washington: A Reconstruction of Seasonally Used Resource Sites." In Robert Boyd, ed. Indians, Fire and The Land In The Pacific Northwest (Corvallis: Oregon State University Press, 1991): 65-93.

Pinchot, Cornelia Bryce. "Address of Mrs. Gifford Pinchot at the Dedication of Gifford Pinchot National Forest." Forest History Today (Spring 1999): 3842.

Pinkett, Harold T. "Western Perceptions of Forest Conservation." Journal of the West. 28, 4 (October 1979): 72-74.

Rakestraw, Lawrence, ed. "Documents: Gifford Pinchot, Agnes V. Scannell, and The Early Years of the U.S. Forest Service." Oregon Historical Quarterly 92, 1 (Spring 1991): 60-75.

. "Uncle Sam's Forest Reserves." Pacific Northwest Quarterly. 44, 4 (October 1953): 145-151.

Robbins, William G. "Federal Forestry Cooperation: The Fernow-Pinchot Years." Journal of Forest History. 28, 4 (October 1984): 164-173.

Ronda, James P. "Coboway's Tale: A Story of Power and Places Along the Columbia." In Power and Place in the American West. ed. Richard White and John Findlay. Seattle: University of Washington Press, 1999.

Schurz, Carl. "The Beginings of Federal Concern." Ed. by Frederick Nash. American Environmentalism: Readings in Conservation History (McGraw Hill, Inc., 1990): 59-62. 
Tolfree, Jamie. "History of the Wind River Lumber Company in the Upper Wind River Valley, Part 1. Skamania County Heritage, 13, No. 3, December 1984.

. "History of the Wind River Lumber Company in the Upper Wind River Valley, Part 2." Skamania County Heritage, 13, No. 4, March 1985.

Thayer, Alfred L. "The Fraudulent Homesteader." Conservation. 15, 11 (November 1908): 579-584.

Ulrich, Roberta. "Empty Promises, Empty Nets." Oregon Historical Quarterly. 100, 2 (Spring 1999): 134-157.

Waitt, Richard B. Jr., "Case for periodic, colossal jokulhlaups from Pleistocene glacial Lake Missoula," Geological Society of America Bulletin 96 (October 1985): $1271-1286$.

\section{Books, Reports, Theses and Dissertations}

Allen, Eliot John, Marjorie Burns, and Sam C. Sargent. Cataclysms on the Columbia: A Layman's Guide to the Features Produced by the Catastrophic Bretz Floods in the Pacific Northwest. Portland, OR: Timber Press, 1986.

Attwell, Jim. Columbia River Gorge History, Volume One. Cascade Locks, Oregon: Tahlkie Books, 1974. Copyright by Jim Attwell.

Axtell, James. The European and the Indian: Essays in the Ethnohistory of Colonial North America. New York: Oxford University Press, 1981.

Balch, Homer. The Bridge of the Gods: A Romance of Indian Oregon. Portland, OR: Binford \& Mort, 1965.

Beckham, Stephen Dow. "This Place is Romantic and Wild": An Historical Overview of the Cascades Area, Fort Cascades, and the Cascades Townsite, Washington Territory. Heritage Research Associates Report No.

27. Eugene: Heritage Research Associates, April 10, 1984. 
Boyd, Robert T. "The Introduction of Infectious Diseases among the Indians of the Pacific Northwest, 1774-1874." ph.d. diss. University of Washington, 1985.

. The Coming of the Spirit of Pestilence: Introduced Infectious

Diseases and Population Decline among Northwest Coast Indians, 17741874. Seattle: University of Washington Press, 1999.

. ed. Indians, Fire and The Land in the Pacific Northwest. Corvallis: Oregon State University Press, 1999.

Crosby, Alfred. Ecological Imperialism: The Biological Expansion of Europe, 900-1900. Cambridge University Press, 1986.

Cronon, William. Changes in the Land: Indians, Colonists, and the Ecology of New England. New York: Hill \& Wang, 1983.

Cunningham, Jr., Noble E. Jefferson vs. Hamilton: Confrontations That Shaped a Nation. Boston and New York: Bedford/St. Martins, 2000.

Dietrich, William. Northwest Passage: The Great Columbia River. New York: Simon \& Schuster, 1995.

Entrikin, Nicholas. The Betweenness of Place: Towards a Geography of Modernity. Baltimore: Johns Hopkins University Press, 1991.

Frome, Michael. Whose Woods These Are: The Story of the National Forests. New York: Doubleday \& Company, Inc., 1962.

Forth, William Stuart. "Wesley L. Jones: A Political Biography." ph.d. diss. University of Washington, 1962.

Harris, Cole. The Resettlement of British Columbia: Essays on Colonialism and Geographical Change. Vancouver, British Columbia: U.B.C. Press, 1997.

Hines, Donald M. The Forgotten Tribes: Oral Tales of the Teninos And Adjacent Mid-Columbia River Indian Nations. Issaquah, Washington: Great Eagle Publishing, 1991.

Hines, Donald M. Where the River Roared: the Wishom Tales. Issaquah, WA: Great Eagle Publishing, 1998. 
Hirt, Paul, ed.. Northwest Lands, Northwest Peoples: Readings in Environmental History. Seattle: University of Washington Press, 1999.

Hunn, Eugene S. with James Selam and Family. Nch'i-Wána "The Big River": Mid-Columbia Indians and Their Land. Seattle: University of Washington Press, 1990.

Johnson, David Alan. California, Oregon and Nevada, 1840-1890: Founding the Far West. Berkeley and Los Angeles: University of California Press, 1992.

Jones, Suzi. The Stories We Tell: An Anthology of Oregon Folk Literature. ed. by Suzi Jones and Jarold Ramsey. Corvallis: Oregon State University Press. 1994.

Kresk, Ray. Fire Lookouts Of The Northwest. Fairfield, Washington: Ye Galleon Press, 1984.

Limerick, Patricia. Legacy of Conquest: The Unbroken Past of the American West New York: W.W. Norton \& Company, 1988.

Mack, Cheryl A. "Past Human Uses of the Wind River Watershed." Vancouver, WA: Gifford Pinchot National Forest, Wind River Ranger District South Skills Center, October, 1995.

Mathews, Daniel. Cascade-Olympic Natural History: A Trailside Reference, 2d. ed. Portland: Raven Editions, 1999.

McClure, Richard and Cheryl Mack, with contributions by Terry L. Ozbun, John L. Fagan, and Gary C. Bower. "Data Recovery Excavations at the Trout Creek Archaeological Site (45SA222), Gifford Pinchot National Forest. Vancouver, WA: Gifford Pinchot National Forest Heritage Program, August 1999.

McClure, Richard and Cheryl Mack. For the Greatest Good: Early History of Gifford Pinchot National Forest. Vancouver, WA: Northwest Interpretive Association, 1999.

Meinig, Donald W. The Great Columbia Plain: A Historical Geography, $1805-$ 1910. Seattle: University of Washington Press, 1968, 1995.

Merchant, Carolyn. Ecological Revolutions: Nature, Gender, and Science in New England. Chapel Hill: University of North Carolina Press, 1989. 
Miller, Char. Gifford Pinchot and the Making of Modern Environmentalism. Washington D.C.: Island Press. Copyright by Char Miller, 2001.

Minor, Rick. Archaeological Testing at 45SA16, Skamania County, Washington. Report to Portland District U.S. Army Corps of Engineers. Eugene: Heritage Resource Associates Report No. 33. December 21, 1984.

- Cultural Resource Overview and investigations for the Bonneville Lock Project, Oregon and Washington. Eugene: Heritage Resource Associates Report No. 29, June 22, 1984.

Minor, Rick, et. al. Overview of Investigations at 45SA11. Archaeology of the Columbia River Gorge. Eugene: Heritage Research Associates, 1989.

Neils, Selma. The Klickitat Indians. Portland: Binford \& Mort, 1985.

Peattie, Roderick. The Cascades: Mountains of the Pacific Northwest. New York: The Vanguard Press, 1949.

Petulla, Joseph M. American Environmental History: The Exploitation And Conservation of Natural Resources. San Francisco: Boyd \& Fraser Publishing Company, 1977.

Pinkett, Harold T. Gifford Pinchot: Private and Public Forester. Chicago: University of Illinois Press, 1970.

Prior, Jan. "Kinship, Environment and the Forest Service Homesteading in Oregon's Coast Range." M.A. Thesis. Oregon State University, 1998.

Pyne, Stephen J. Year of the Fires: The Story of the Great Fires of 1910. New York: Viking Press, 2001.

Rakestraw, Lawrence. "A History of Forest Conservation in the Pacific Northwest, 1891-1913.” Ph.D. diss. University of Washington, 1955.

Ramsey, Jarold. Coyote Was Going There: Indian Literature of the Oregon Country. Compiled and edited by Jarold Ramsey. Seattle: University of Washington Press, 1980.

Richards, Kent D. Isaac I. Stevens: Young Man In A Hurry. Provo, Utah: Brigham Young University Press, 1979. 
Robbins, William G. American Forestry: A History of National, State, \& Private Cooperation. Lincoln: University of Nebraska Press, 1985.

. Landscapes of Promise: The Oregon Story 1800-1940.

Seattle: University of Washington Press, 1997.

Rubin, Rick. Naked Against the Rain: The People of the Lower Columbia River. Portland: Far Shore Press, 1999.

Sack, Robert David. Homo Geographicus: A Framework for Action, Awareness, and Moral Concern. Baltimore: John Hopkins University Press, 1997.

Sams, Dorothy. History of Skamania County. Stevenson, WA: History Committee, Skamania County Community Development Program, 1958.

Schwantes, Carlos. The Pacific Northwest: An Interpretive History. Lincoln: University of Nebraska Press, 1989.

Silverstein, Michael. "Chinookans of the Lower Columbia" in Handbook of North American Indians. Vol. 7, Northwest Coast. William Sturtevant, general editor. Washington D.C.: Smithsonian, 1990.

Skinner Alan, et. al. Clah-Cleh-Lah: An Archeological Site at Bonneville Dam, Washington. Contract No. DACW57-78-C-0029. Environment Consultants, Inc. Portland, OR: U.S. Army Corps of Engineers, July 1981.

Spier, Leslie. Tribal distribution in Washington. General Series in Anthropology, Vol. 3. Menasha, Wisconsin: George Banta Publishing Company, 1936.

Spier, Leslie and Edward Sapir. Wishram Ethnography. University of Washington Publications in Anthropology. Vol. 3, No. 3, May, 1930.

Spranger, Michael. The Columbia Gorge. Pullman: Washington State University Press, 1993.

State of Washington. The Washington State 1999 Data Book. State of Washington: Office of Financial Management, 1999.

Steen, Harold. "Forestry in Washington to 1925." Ph.D. thesis, University of Washington, 1969. 
Thoele, Michael. Bohemia: The Lives and Times of an Oregon Timber Venture. Portland: Oregon Historical Society Press, 1998.

Townsend, Homer and Alice. Skamania: A Columbia River Gorge Community in the 1920s. Copyright by Homer and Alice Townsend, 1986.

Trafzer, Clifford E., ed. Indians, Superintendents, and Councils: Northwest Indian Policy, 1850-1855. San Diego, CA: University Press of America, 1986.

Trafzer, Clifford E. and Richard D. Scheurman. Renegade Tribe: the Palouse Indians and the invasion of the inland Pacific Northwest. Pullman, WA: Washington State University Press, 1986.

Tuan, Yi-Fu. The Good Life. Madison: University of Wisconsin Press, 1986.

. Space and Place: The Perspective of Experience. Minneapolis: University of Minnesota Press, 1977.

U.S.D.A. Department of Agriculture, Forest Service. Wind RiverBasin Watershed Analysis: Gifford Pinchot National Forest. Gifford Pinchot National Forest: Wind River Ranger District South Skills Center, April 1996.

White, Richard. Organic Machine: The Remaking of the Columbia River. New York: Hill and Wang, 1995.

. Land Use, Environment, and Social Change: The Shaping of Island County, Washington. Seattle: University of Washington Press, 1980.

Wilkes, Charles, U.S.N. Commander United States Exploring Expedition, 1839 to 1842. Columbia River to the Sacremento (Oakland: Biobooks, 1958).

Williams, Chuck. introduction by David R. Brower. Bridge of the Gods, Mountains of Fire: A Return to the Columbia River Gorge. San Francisco and White Salmon: Friends of the Earth \& Elephant Mountain Arts, in cooperation with Columbia Gorge Environmental Center, 1980.

Worster, Donald. Nature's Economy: A History of Ecological Ideas. New York: Cambridge University Press, 1977. reprint, 1988.

Yarbrough, Jean. American Virtues: Thomas Jefferson on the Character of a Free People. Lawrence: University of Kansas Press, 1998. 


\section{Newspapers \\ Skamania County Pioneer \\ Carson Journal}

\section{Websites}

Center for Columbia River History Website. Primary Documents, Camas and Columbia Slough Community Histories, www.ccrh.org [Internet, accessed January 2004].

Lane J. Bouman. "The Location of Oregon Donation Land Claims." Professional Land Surveyors of Oregon Website, http://www.plso.org/readingroom/OregonDLC-Bouman.htm [Internet, accessed January 4, 2004].

Forest History Society Website. "U.S. Forest Service History." http://www.lib.duke.edu/forest/usfscoll/index.html [Internet, accessed January 2004].

Library of Congress, American Memory: Historical Collections for the Digital Archives, http://memory.loc.gov/ [Internet, accessed January 5, 2004].

University of Washington Digital Collections, American Indian Collection http://content.lib.washington.edu/aipnw/index.html [Internet, accessed January 2004].

U.S.G.S. Website, http://landslides.usgs.gov/html_files/bonneville/, http://vulcan.wr.usgs.gov/Glossary/Glaciers/IceSheets/Waitt85GSA/abstract .html, http://vulcan.wr.usgs.gov/Glossary/Glaciers/IceSheets/description_lake_mis soula.html [Internet, accessed January 1, 2004]. 